\title{
Defense Waste Transportation Cost and Logistics Studies
}

W. B. Andrews

B. M. Cole

R. L. Engel

J. M. Oylear

August 1982

Work Supported by the U.S. Department of Energy

Through the Transportation Technology Center at Sandia National Laboratories under Contract DE-AC06-76RLO 1830

Pacific Northwest Laboratory Operated for the U.S. Department of Energy by Battelle Memorial Institute 


\title{
DISCLAIMER
}

This report was prepared as an account of work sponsored by an agency of the United States Government. Neither the United States Government nor any agency thereof, nor any of their employees, makes any warranty, express or implied, or assumes any legal liability or responsibility for the accuracy, completeness, or usefulness of any information, apparatus, product, or process disclosed, or represents that its use would not infringe privately owned rights. Reference herein to any specific commercial product, process, or service by trade name, trademark, manufacturer, or otherwise, does not necessarily constitute or imply its endorsement, recommendation, or favoring by the United States Government or any agency thereof. The views and opinions of authors expressed herein do not necessarily state or reflect those of the United States Government or any agency thereof.

\author{
PACIFIC NORTHWEST I.ABORATORY \\ operated by \\ BATTELLE \\ for the \\ UNITED STATES DEPARTMENT OF ENERGY \\ under Contract DE-AC06-76RLO 1830
}

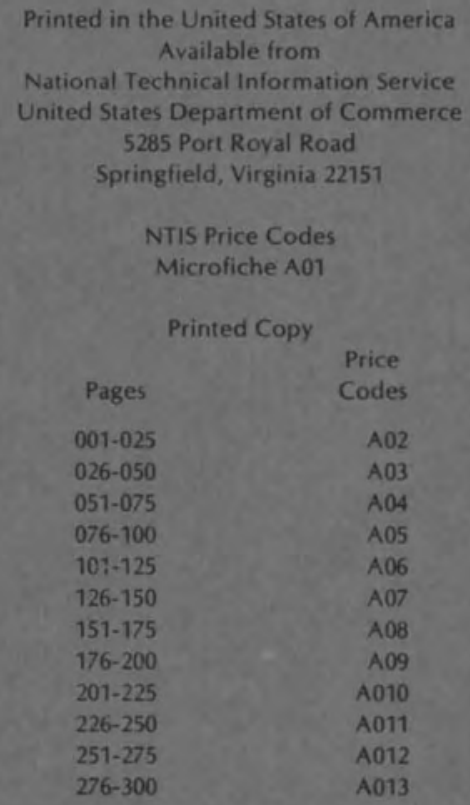


W. B. Andrews

B. M. Cole

R. L. Engel

J. M. Oylear

August 1982

Work Supported by the U.S. Department of Energy Through the Transportation Technology Center at Sandia National Laboratories under Contract DE-AC06-76RLO 1830

Pacific Northwest Laboratory Richland, Washington 99352 



\section{PREFACE}

This document was prepared as part of the Waste Transportation Technology Studies Project and provides logistics and cost information for alternative DOE waste transportation systems. The scope of the work was 1 imited to the shipment of contact-handled transuranic (CH-TRU), processed-TRU (PTRU), and high-7eve 1 defense wastes from major government generating sites to waste isolation facilities. Funding for this work was provided by the U.S. Department of Energy (DOE) through the Transportation Technology Center (TTC) at Sandia National Laboratories. 


\section{ACKNOWLEDGMENTS}

The authors would like to express their appreciation to Mr. Robert Cross at Rockwe11-Hanford Company, Mr. J. A. Bucholz at Oak Ridge National Laboratory and Ms. K. E. Rodriguez at PNL for their invaluable contributions to the work in this report. Mr. Cross provided assistance, guidance, and research in the development of transportation shipping rates and transit times used in this study. Mr. Bucholz developed high-level defense waste cask characteristics for alternative waste canister dimensions. Ms. Rodriguez provided patient editorial advice. 


\section{ABSTRACT}

Transportation of nuclear wastes from defense programs is expected to significantly increase in the 1980s and 1990 s as permanent waste disposal facilities come into operation. This report uses models of the defense waste transportation system to quantify potential transportation requirements for treated and untreated contact-handled transuranic ( $\mathrm{CH}-\mathrm{TRU})$ wastes and highlevel defense wastes (HLDW). Alternative waste management strategies in repository siting, waste retrieval and treatment, treatment facility siting, waste packaging and transportation system configurations were examined to determine their effect on transportation cost and hardware requirements.

A11 cost estimates used 1980 costs. No adjustments were made for future changes in these costs relative to inflation. All costs are reported in 1980 dollars. If a single repository is used for defense wastes, transportation costs for CH-TRU waste currently in surface storage and similar wastes expected to be generated by the year 2000 were estimated to be 109 million dollars. Recovery and transport of the larger buried volumes of $\mathrm{CH}$-TRU waste wi11 increase $\mathrm{CH}-\mathrm{TRU}$ waste transportation costs by a factor of 70 . Emphasis of truck transportation and siting of multiple repositories would reduce $\mathrm{CH}-\mathrm{TRU}$ transportation costs. Transportation of HLDW to repositories for 25 years beginning in 1997 is estimated to cost $\$ 229 \mathrm{M}$ in 1980 costs and dollars. HLDW transportation costs could either increase or decrease with the selection of a final canister configuration. HLDW transportation costs are reduced when multiple repositories exist and emphasis is placed on truck transport. 
. 


\section{CONTENTS}

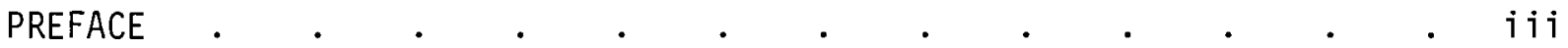

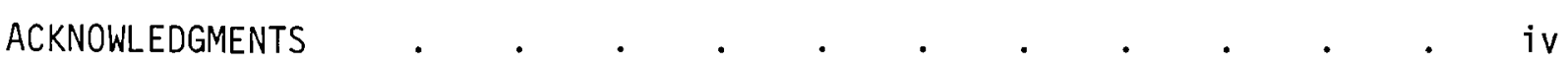

ABSTRACT

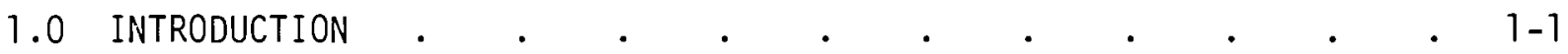

2.0 SUMMARY . . . . . . . . . . . . . . . . . . . . $2-1$

2.1 SUMMARY OF CONTACT-HANDLED DEFENSE WASTE TRANSPORTATION
ALTERNATIVES

2.2 SUMMARY OF HLDW TRANSPORTATION ALTERNATIVES . . . . . 2-5

3.0 WASTE TRANSPORTATION SYSTEM MODEL . . . . . . . . . . . . . $3-1$

3.1 TRANSPORTATION LOGISTICS MODULE . . . . . . . 3-3

3.2 TRANSPORTATION COST MODULE . . . . . . . . . .

3.2.1 Transport Container Requirements . . . . . . 3-5

3.2.2 Capital Costs . . . . . . . . . . . $3-5$

3.2 .3 Operating Costs . . . . . . . . . . . . $3-6$

3.2.4 Levelized Unit Costs . . . . . . . . . 3-7

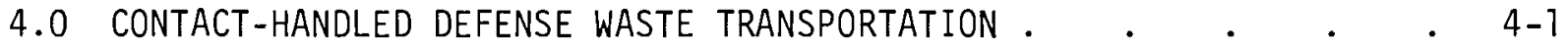

4.1 CONTACT-HANDLED DEFENSE WASTE DESCRIPTIONS . $\quad . \quad$.

4.1.1 CH-TRU Waste Volumes . . . . . . . . 4-1

4.1.2 CH-TRU Waste Canisters . . . . . . . 4-6

4.1.3 $\mathrm{CH}$-TRU Waste Treatment Processes and Treated Waste
Forms

4.2 CONTACT-HANDLED DEFENSE WASTE TRANSPORTATION SYSTEMS • • 4-10

4.2.1 CH-TRU Shipping System . . . . . . . 4-10

4.2.2 PTRU Waste Shipping System . . . . . . . 4-13 
4.3 ALTERNATIVES FOR CONTACT-HANDLED DEFENSE WASTE TREATMENT/ SHIPMENT . . . . . . . . . . . 4-15

4.4 CONTACT-HANDLED DEFENSE WASTE SHIPPING COST COMPARISONS AND TRANSIT TIMES $\cdot$.

4.4.1 CH-TRU Waste Shipments. . . . . . . 4-18 4.4.2 PTRU Waste Shipments . . . . . . . . 4-26

4.5 RESULTS OF CONTACT-HANDLED DEFENSE WASTE TRANSPORTATION COST AND LOGISTICS ANALYSES . . . . . . • . . . 4-26

4.5.1 CH-TRU Waste Transportation Reference Case. . . 4-32

4.5.2 Transportation System Effects Due to Buried CH-TRU Waste Disposal . . . . . . . . 4-33

4.5.3 Transportation System Effects of Treating CH-TRU Wastes . . . . . . . . . 4 4-34

4.5.4 Effects of Transportation System Alternatives . . 4-35

4.5.5 Transportation Effects of Regional Repositories. . 4-41

4.5.6 Transportation Effects of Facility Location . . 4-41

4.5.7 Sensitivity Analysis . . . . . . . . 4 . 4-46

5.0 HIGH-LEVEL DEFENSE WASTES TRANSPORTATION . . . . . . . 5-

5.1 HIGH-LEVEL DEFENSE WASTES SOURCES AND VOLUMES . . . . 5-1

5.2 HIGH-LEVEL DEFENSE WASTES SHIPPING SYSTEMS • • • . • 5-2

5.3 HIGH-LEVEL DEFENSE WASTES SHIPMENT SCENARIOS . . . . 5-3

5.4 HIGH-LEVEL DEFENSE WASTES SHIPPING COSTS AND TRANSIT TIMES • 5-4

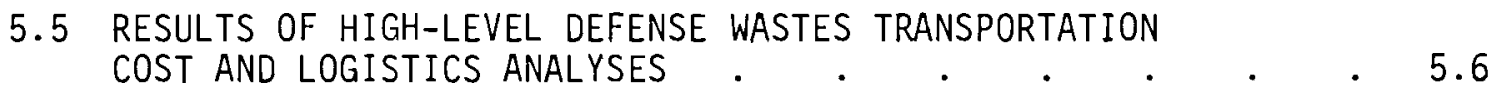

5.5.1 Transportation Requirements for HLDW Reference
Case . . . . . . . . 5-6

5.5.2 Effects on HLDW Transportation Requirements Caused by Alternate Canister Sizes and Shipping Cask Designs . $\quad . \quad . \quad . \quad . \quad . \quad . \quad . \quad . \quad 5-9$ 


\begin{tabular}{|c|c|c|c|c|c|c|c|c|c|}
\hline & 5.5 .3 & \multicolumn{4}{|c|}{$\begin{array}{l}\text { Effects on HLDW Transportation } \\
\text { Truck Versus Rail Shipments. }\end{array}$} & \multicolumn{3}{|c|}{ Requirements Due to } & $5-9$ \\
\hline & 5.5 .4 & $\begin{array}{l}\text { Effects on } \\
\text { Repository }\end{array}$ & $\begin{array}{l}\text { HLDW Transp } \\
\text { Location }\end{array}$ & ortat & ion & Due to & Multiple & • & $5-11$ \\
\hline & 5.5 .5 & $\begin{array}{l}\text { Effects on } \\
\text { Repository }\end{array}$ & $\begin{array}{l}\text { HLDW Transp } \\
\text { Locations }\end{array}$ & ortat & ion & Caused & by Altern & te & $5-12$ \\
\hline REFERENCES & - & - & . & . & . & . & . & . & - $\operatorname{Ref}-1$ \\
\hline GLOSSARY & - & - & . & - & . & - & - & • & $G-1$ \\
\hline APPENDIX & $A-T L M$ & OPERATING & [NSTRUCT IONS & . & . & . & . & . & $A-1$ \\
\hline APPENDIX & $3-\mathrm{TCM}$ & OPERAT ING & [NSTRUCTIONS & - & - & - & . & . & $B-1$ \\
\hline
\end{tabular}





\section{FIGURES}

3.1 PNL Waste Transportation Cost and Logistics Model . . . . 3-2

4.1 Locations of Facilities Generating and Storing Defense CH-TRU Wastes . . . . . . . . . 4-2

4.2 Map of Four Regions. . . . . . . . . . . 4-16

4.3 Rail Shipping Costs for CH-TRU Waste . . . . . . 4-24

4.4 Rail Transit Time for CH-TRU Waste. . . . . . . 4-24

4.5 Truck Transit Time for CH-TRU Waste . . . . . . 4-25

4.6 PTRU Rail Shipping Costs . . . . . . . . . . . 4-30 



\section{$\underline{\text { TABLES }}$}

2.1 Summary of CH-TRU Transportation Total Costs from Scenario Alternatives . . . . . . . . . 2-3

2.2 Summary of HLDW Transportation Total Costs from Scenario Alternatives . . . . . . . . . . 2-6

4.1 Estimated Volumes of Defense CH-TRU Wastes in Surface Storage . 4-3

4.2 Estimated Volumes of Buried Defense CH-TRU Wastes . . . . 4-4

4.3 Origin of $\mathrm{CH}$-TRU Wastes in Surface Storage at the INEL . . . 4-5

4.4 Uncertainties for Estimated Volumes of $\mathrm{CH}$-TRU Wastes . . . 4-6

4.5 Types of Canisters Used in CH-TRU Waste . . . . . . 4-8

$4.6 \mathrm{CH}$-TRU Waste Packages . . . . . . . . . 4-9

4.7 Assumed Cost and Lifetime of CH-TRU Shipping Packagings . . 4-11

4.8 Shipping Modes and Waste Capacities of $\mathrm{CH}-\mathrm{TRU}$ Shipping

4.9 Capacities of PTRU Shipments Using Type B Packagings . . . 4-14

4.10 Capacities of PTRU Shipments in the Low-Level Solids Classifications . . . . . . . . . . 4-15

4.11 Number of Waste Canisters per Shipping Packaging . . . . 4-19

4.12 Average Waste Canister Weights . . . . . . . 4-19

4.13 Contact-Handled Defense Waste Shipping Costs and Transit Times to the Southwest Repository. . . . . . . . .

4.14 Contact-Handled Defense Waste Shipping Costs and Transit Times to Idaho Falls, Idaho. . . . . . . . 4-22

4.15 Contact-Handled Defense Waste Shipping Costs and Transit Times to Hanford, Washington. . . . . . . . . . 4-23

4.16 Truck Shipping Costs Rates . . . . . . . . 4-25

4.17 One-Way Distances to Regiona 1 and Alternate Western Repository Sites 
4.18 CH-TRU Shipping Costs to Regional and Alternate Western Repository Sites, \$/Roundtrip. . . . . . . . . 4-28

4.19 One-Way Transit Times to Regional and Alternate Western Repository Sites, Days . . . . . . . . . . . . 4 4 4

4.20 PTRU Shipping Packaging Types and Weights . . . . . 4-29

4.21 Shipping Costs for PTRU Rates to the Southwestern Repository Using Disposable Type B Packagings . . . . . . . 4-29

4.22 Shipping Costs and Transit Times for PTRU Disposable Packages to the Regional and Alternate. Western Repository . . 4-30

4.23 Shipping Costs and Transit Times for PTRU Non-Disposable Packagings to the Regional and Alternate Western Repository . . 4-31

4.24 Effects of Accelerated Emplacement . . . . . . . 4-33

4.25 Effects of Emplacing Additional CH-TRU Waste Categories . . 4-34

4.26 Effects of Pretreating CH-TRU Wastes . . . . . . 4-35"

4.27 Effects of Rail Versus Truck Delivery . . . . . . 4-36

4.28 Effects of Alternate CH-TRU Waste Transportation System . . 4-38:

4.29 Effects of Alternate PTRU Transportation System - Single Treatment Facility . . . . . . . . . . 4-39

4.30 Effects of Alternate PTRU Transportation System - Two Treatment Facilities . . . . . . . . . . . 4 4 40

4.31 Effects of Regional Repositories . . . . . . . 4-4

4.32 Effects of Alternate Repository Locations - Single Repository with No Treatement . . . . . . . . . . . 4-43

4.33 Effects of Alternate Repository Locations - Single Treatment
Facility at the INEL and Single Repository . . . 4-43

4.34 Effects of Alternate Western Regional Repository Locations -
Single Treatment Location at the INEL . . 4-44

4.35 Effects of Alternate Repository Locations - Two Treatment Facilities at the INEL and Hanford and Single Repository . . 4-44

4.36 Effects of Locating Treatment Facility at Repository . . . 4-45 
4.37 Sensitivity of Transportation Requirements to Changes in Basic Values. . . . . . . . . . . 4-46

5.1 HLDW Canister Production . . . . . . . . . . 5-1

5.2 HLDW Shipping Casks. . . . . . . . . . . $5-2$

5.3 Rail Shipping Costs for HLDW . . . . . . . . 5-5

5.4 HLDW Cask Specifications . . . . . . . . . . 5-5

5.5 Transit Times to Regional and Alternate Western HLDW

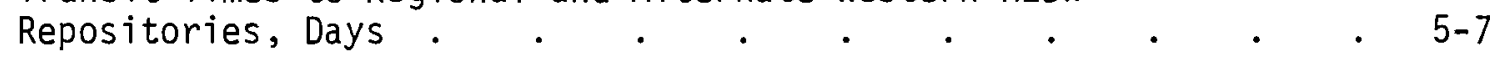

5.6 Distances to Regional and Alternate Western HLDW Repositories, Kilometers... . . . . . . . 5-7

5.7 Rail HLDW Shipping Costs for Cask Concept 7 (Reference Case) . 5-7

5.8 Rail HLDW Shipping Costs for Alternate Cask Concepts . . . 5-8

5.9 Truck HLDW Shipping Costs for A11 Cask Concepts . . . . 5-8

5.10 HLDW Transportation Effects Due to Alternate Canister Size and Shipping Cask Design (Percentage Change from Base is Shown in Parenthesis) . . . . . . . . . . 5-10

5.11 HLDW Transportation Effects if 50\% HLW Volume is Shipped by Truck Instead of A1l Rail Shipments (Percent Change is Shown in Parenthesis)

5.12 HLDW Transportation Effects Due to Multiple Repository Locations (Cask Concept 7) . . . . . . . .

5.13 HLDW Transportation Effects Due to Alternate Repository Locations National Repository (Cásk Concept 7) . . . . . . 5-13

5.14 HLDW Transportation Effects Due to Alternate Western Repository Locations - Regional Repositories . . . . . . . 5-13

A.1 TLM Control Cards . . . . . . . . . . . A-3

B. 1 Sample Input Deck . . . . . . . . . . . B-2 



\subsection{INTRODUCTION}

Shipments of government-owned or -controlled nuclear waste materials are expected to significantly increase in the future as facilities for interim storage and permanent disposal of high-level and transuranic (TRU) wastes from national defense programs begin operation. Of primary importance is the availability of a safe, efficient and environmentally acceptable means of transporting nuclear waste materials to these facilities.

The objective of this study is to provide quantitative cost and logistics information for alternative DOE waste transportation systems and waste management strategies. The information can then be used in support of evaluation, planning and design of waste handling facilities and to determine requirements of transportation systems connecting these facilities.

Defense wastes can be divided into three categories: high-level, intermediate-level TRU, and contact-handled TRU. High-level defense wastes (HLDW) originate from primary waste streams in spent fuel reprocessing operations. Due to the high activity of the associated fission products, these wastes require remote handling in heavily shielded facilities. Remote-handled defense wastes (RHDW) consist of materials which are sufficiently contaminated with fission products and TRU nuclides to have a container surface dose rate in excess of $200 \mathrm{mrem} / \mathrm{hr}$. Contact-handled TRU (CH-TRU) wastes have a maximum surface dose rate of $200 \mathrm{mrem} / \mathrm{hr}$ and are handled using conventional equipment operated to minimize operator exposures. $\mathrm{CH}-\mathrm{TRU}$ wastes can be untreated (as generated) or treated to alter physical characteristics. The latter is referred to as processed TRU (PTRU) waste. The scope of this study includes the transportation of CH-TRU, PTRU, and HLDW. RHDW were not considered.

The remainder of this report is organized into four sections. Section 2 presents the summary of the logistics and cost information obtained from the system study. Section 3 describes the cost and logistics models used to analyze the waste transportation systems. Section 4 discusses the analysis of transportation systems for CH-TRU and PTRU wastes considered in this study. 
Section 5 describes the analysis of transportation systems for HLDW. Each of the major sections on CH-TRU wastes and HLDW are further divided into descriptions of waste volumes and canisters, transportation systems, shipping costs and shipping strategies considered in the analysis and results. 


\subsection{SUMMARY}

This report presents a description of defense waste transportation systems and an analysis of requirements for transport from the source of the waste to a repository for final disposal. The analysis is divided into discussions of contact-handled defense wastes and high-level defense wastes (HLDW). Contacthandled defense wastes are transuranic wastes with surface dose rates below $200 \mathrm{mrem} / \mathrm{hour}$. This category includes both untreated contact-handled transuranic (CH-TRU) and processed transuranic (PTRU) wastes. Remote-handled defense wastes are not considered in this report.

\subsection{SUMMARY OF CONTACT-HANDLED DEFENSE WASTE TRANSPORTATION ALTERNATIVES}

CH-TRU defense wastes are currently being generated and placed in surface storage at several sites in the U.S. at an annual rate of nearly $5000 \mathrm{~m}^{3}$. By 1990, the accumulated backlog of surface-stored waste is expected to be in excess of $100,000 \mathrm{~m}^{3}$. If a shipping rate of $10,000 \mathrm{~m}^{3} / \mathrm{yr}$ is assumed a minimum 20-year repository life (starting in 1997) is required to eliminate the backlog of surface-stored waste. CH-TRU waste generated before surface storage was practiced have been buried at several sites in the U.S. If a waste management policy is adopted to retrieve and relocate these buried wastes, waste volumes to be transported could exceed 1,000,000 $\mathrm{m}^{3}$ (DOE 1981).

Conversion of $\mathrm{CH}$-TRU wastes to less mobile forms may be required for disposal. The Slagging Pyrolysis Incineration (SPI) process which is under development at the Idaho National Engineering Laboratory (INEL) is the conversion process assumed for this analysis. Processing contact-handled waste is expected to reduce the volume to about one-half the untreated volume.

Current transportation industry practices (1980) were examined to determine shipping charge rates and transit times for both rail and truck shipments. This information (presented in Section 4.4) was used to estimate the total transportation costs and logistics requirements for shipping contact-handled defense wastes to a repository.

Several contact-handled defense waste shipment/treatment alternatives were examined to determine their effects on transportation costs and logistics. The alternatives include: 
- various annual shipping rates

- retrieval and transport of buried wastes

- treatment at one or more facility locations

- transportation by truck or rail

- shipping container alternatives

- number and location of repositories.

Total transportation costs are estimated to be $\$ 109$ million for the reference case, which assumed the disposal of surface-stored $\mathrm{CH}-\mathrm{TRU}$ wastes plus a 11 future $\mathrm{CH}$-TRU waste generated for 20 years, at a single repository located in the Southwest. These costs include capital outlay for purchasing reusable shipping packagings, maintenance cost of reusable packagings, and charges by commercial carriers to transport the wastes. The $\mathrm{CH}$-TRU wastes were assumed to be shipped in TRUPACT packagings, under development at the Transportation Technology Center. Seventy five percent of the volume was assumed shipped by rail and the remainder by truck. TWo TRUPACT designs were assumed, one for truck transport and a larger one for rail transport. Two rail TRUPACTs can be carried on a standard rail flatcar. The impact of variations from the base case on 20-year CH-TRU waste transportation costs is summarized in Table 2.1. Some alternatives for PTRU waste transportation include disposal of the shipping package as waste. In these cases, shipping package costs were considered as a processing cost and are not included in this analysis.

An accelerated disposal rate that removes the backlog of surface-stored wastes in about four years was considered. This alternative increases the total transportation cost by about $\$ 35$ million compared to removing the back$\log$ in 20 years. Increased costs are due to low utilization of shipping packagings after the stored waste backlog is eliminated.

Exhuming, repackaging and disposal of $1,000,000 \mathrm{~m}^{3}$ of buried wastes and associated contaminated soil would have the largest impact on defense $\mathrm{CH}-\mathrm{TRU}$ transportation requirements. The transportation cost is 74 times as large as that for surface-stored wastes. The effects of selecting the other alternatives were determined with only the disposal of surface-stored wastes. If the buried wastes are retrieved, the potential impacts of the other alternatives become correspondingly larger. 
TABLE 2.1. Summary of $\mathrm{CH}-\mathrm{TRU}$ Wastes Transportation Total Costs from Scenario Alternatives

\begin{tabular}{|c|c|c|c|c|}
\hline Alternatives & $\begin{array}{l}\text { Description of } \\
\text { Alternatives }\end{array}$ & $\begin{array}{l}\text { otal Cost Range } \\
(\$ \text { million })(a)\end{array}$ & $\begin{array}{c}\text { Reference } \\
\text { Case Cost } \\
(\$ \text { million }) \\
\end{array}$ & \begin{tabular}{l}
\multicolumn{1}{c}{ Maximum } \\
Difference from \\
Reference Case \\
$(\$$ million $)(a)$ \\
\end{tabular} \\
\hline Accelerated Disposal Rate & $\begin{array}{l}\text { Ship Backlog in } 4 \\
\text { Years }\end{array}$ & $109-144$ & 109 & +35 \\
\hline Buried Waste Relocation & $\begin{array}{l}\text { Exhume, Package, } \\
\text { Ship Buried Wastes } \\
\text { Contaminated Soil }\end{array}$ & $526-8230$ & 109 & +8121 \\
\hline Treatment Strategy & Treat the Wastes & $81-109$ & 109 & -28 \\
\hline Shipping Mode & Truck or Rail & $77-109$ & 109 & -32 \\
\hline \multicolumn{5}{|l|}{ Container Type } \\
\hline CH-TRU Wastes & Existing vs. Conceptual & $45-119$ & 109 & $-64,+10$ \\
\hline PTRU Wastes & Disposable vs. Reusable & $94-235$ & 94 & +141 \\
\hline Regional Repository & 3 Regional Repositories & $80-94$ & 94 & -14 \\
\hline \multicolumn{5}{|l|}{ Repository Location } \\
\hline $\begin{aligned} \text { No Treatment - } & \text { Single } \\
& \text { Repository }\end{aligned}$ & 1 of 4 Western Locations & $65-109$ & 109 & -44 \\
\hline $\begin{aligned} \text { Treatment }- & \text { Single } \\
& \text { Repository }\end{aligned}$ & \multicolumn{4}{|l|}{1 of 4 Western Locations } \\
\hline Single Facility & Idaho Falls & $70-94$ & 94 & -24 \\
\hline Two Facilities & Hanford, Idaho Falls & $53-81$ & 81 & -28 \\
\hline $\begin{aligned} \text { Treatment }- & 3 \text { Regional } \\
& \text { Repositories }\end{aligned}$ & \multicolumn{4}{|l|}{ West, South, Northeast } \\
\hline No Treatment & $\begin{array}{l}\text { Wastes Treated at } \\
\text { Repository }\end{array}$ & $58-80$ & 80 & -22 \\
\hline Treatment & $\begin{array}{l}\text { Wastes Treated at } \\
\text { Source }\end{array}$ & $40-66$ & 66 & -26 \\
\hline
\end{tabular}

(a) Costs are in 1980 dollars and based on 1980 published transportation tarrifs. 
If $\mathrm{CH}-\mathrm{TRU}$ wastes are processed before disposal, transportation costs can be reduced by as much as $\$ 28$ million. This estimate is based on one or two treatment facilities located in the Northwest. The PTRU wastes were assumed to be shipped to a Southwest repository in disposable packages. Transportation costs in this case include the shipments of $\mathrm{CH}$-TRU wastes to the treatment facility but do not include the costs of the disposal packages.

In general, truck shipments are less expensive than rail shipments but require additional shipments to be made. Shipping all $\mathrm{CH}$-TRU wastes to the repository by truck could reduce the transportation cost by as much as $\$ 32$ million.

Alternative shipping packagings were considered for both $\mathrm{CH}-\mathrm{TRU}$ and PTRU waste shipments. If CH-TRU wastes are shipped to the repository in the ATMX transporter by rail and in the Super Tiger $^{\oplus}$ by truck, transportation cost is reduced by $\$ 64$ million. If only the truck-sized TRUPACT is developed for use by truck and rail, transportation costs would increase $\$ 10 \mathrm{million}$. The selection of reusable PTRU waste shipping packagings could increase the transportation costs as much as $\$ 141$ million compared to the disposable packages assumed in the reference case. (However the disposable packages are considered part of the processing costs and are not included in the transportation costs.)

If treatment and disposal is implemented on a regional basis, a reduction of $\$ 14$ million in transportation cost is possible, as compared to the single treatment facility with one national repository.

Four alternate western repository locations were considered in this analysis, one in the Southwest, one in the Mojave Desert in the far Southwest, one in the central Rockies, and one in the Northwest. If CH-TRU wastes are disposed in a single repository with no preprocessing, repository location can reduce transportation costs by $\$ 44$ million. If the wastes are preprocessed and the PTRU wastes are emplaced in a single repository, the repository location can reduce transportation costs by $\$ 24$ million with one treatment facility and $\$ 28$ million with two treatment facilities. For three regional repositories, the location for the western repository can reduce transportation costs by up to $\$ 22$ million 
with a single treatment facility in the western region, and up to $\$ 26$ million with two treatment facilities. In all cases, the southwest location results in the highest transportation cost.

\subsection{SUMMARY OF HLDW TRANSPORTATION ALTERNATIVES}

HLDW are currently being stored at Hanford, Washington, Idaho Falls, Idaho, Savannah River, Georgia, and West Valley, New York. Waste processing facilities, to convert the existing waste inventories into a form suitable for transportation and disposal, were assumed to be built at each site for this analysis. Processing was assumed to begin in 1992. Peak production rates of $3050 \mathrm{~m}^{3} /$ year were assumed to be in effect between year 2000 and 2014 .

Several HLDW shipment/repository alternatives were examined to determine their effects on transportation costs and logistics. The alternatives considered include:

- canister and shipping cask designs and configurations

- transportation by rail or truck

- number and location of repositories.

The impacts of these HLDW transportation system alternatives on HLDW transportation cost are shown in Table 2.2. For HLDW, the transportation costs are for 25 years of repository operation beginning in 1997. The total transportation cost estimate for the HLDW reference case was $\$ 229$ million. This case assumed that all shipments would be by rail to a repository located in the Northwest. Several canister size and shipping cask design combinations are under consideration for implementation. A $0.61 \mathrm{~m}$ diameter by $3 \mathrm{~m}$ length canister in a rail cask designed to hold 7 canisters was used in this study as the reference HLDW transportation configuration. The selection of alternate canister sizes or cask designs can reduce transportation cost from the base case by as much as $\$ 25$ miliion, or can increase transportation cost by as much as $\$ 55$ milition. 
TABLE 2.2. Summary of HLDW Transportation Total Costs from Scenario Alternatives

\begin{tabular}{|c|c|c|c|c|}
\hline Alternatives & $\begin{array}{c}\text { Description of } \\
\text { Alternatives }\end{array}$ & $\begin{array}{l}1 \text { Cost Range } \\
\text { Iiililion)(a) }\end{array}$ & $\begin{array}{c}\text { Reference } \\
\text { Case Cost }(a) \\
(\$ \text { million) } \\
\end{array}$ & $\begin{array}{l}\quad \text { Maximum } \\
\text { Difference from } \\
\text { Reference Case } \\
(\$ \text { million })(a) \\
\end{array}$ \\
\hline $\begin{array}{l}\text { Canister Size and Shipping } \\
\text { Cask }\end{array}$ & $\begin{array}{l}\text { Various Canister } \\
\text { Dimensions }\end{array}$ & $204-284$ & 299 & $-25,+55$ \\
\hline \multirow[t]{2}{*}{ Shipping Mode } & $\begin{array}{l}50 \% \text { Truck } \\
\text { Reference Canister }\end{array}$ & $219-229$ & 229 & -10 \\
\hline & $\begin{array}{l}50 \% \text { Truck, } \\
\text { Alternate Canister }\end{array}$ & $222-277$ & 277 & -55 \\
\hline Repository Policy & $\begin{array}{l}3 \text { Regional Repositories } \\
\text { West, South, Northeast }\end{array}$ & $171-229$ & 229 & -58 \\
\hline \multicolumn{5}{|l|}{ Repository Locations } \\
\hline $\begin{array}{l}\text { Single National } \\
\text { Repository }\end{array}$ & 1 of 4 Western Locations & $229-469$ & 229 & +240 \\
\hline Regional Repositories & $\begin{array}{l}1 \text { of } 4 \text { Western Locations, } \\
\text { plus South, Northeast }\end{array}$ & $171-449$ & 171 & +278 \\
\hline
\end{tabular}

(a) Costs are in 1980 dollars based on 1980 published transportation tariffs. 
If $50 \%$ of the HLDW volume is shipped by truck the transportation cost is reduced by $\$ 10$ million using the reference canister size. If a $1.2 \mathrm{~m}$ diameter by $1.2 \mathrm{~m}$ length canister is used, $50 \%$ truck transit reduces costs by $\$ 55$ million. Onty one canister can be shipped on a truck in either case.

The availability of an additional repository in the Northeast reduces HLDW transportation costs about $\$ 46$ million. The availability of two additional repositories, one in the Northeast and one in the South, can reduce HLDW transportation costs about $\$ 58$ miliion.

Alternate western U.S. Tocations were considered for a national repository. The Northwest repository location was the optimum location from the standpoint of total transportation costs. With a single repository, the selection of an alternate location could add as much as $\$ 240$ million in transportation costs. With regional repositories, the selection of an alternate western location could add as much as $\$ 278$ milition in transportation costs. 


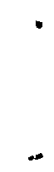




\subsection{WASTE TRANSPORTATION SYSTEM MODEL}

PNL has developed a computer model for simulating transportation of TRU wastes to disposal facilities. This model provides quantitative cost and logistics information on both processed and unprocessed contact-handled TRU and high-level defense waste transportation and handling systems. This information can be used in the performance evaluation, planning and design of alternative waste handling and transportation facilities.

The Cost and Logistics Model (CLM) is outlined in Figure 3.1. The CLM consists of two separate modules, the Transportation Logistics Module (TLM) and the Transportation Cost Module (TCM).

Information required to operate the CLM includes descriptions of waste shipping/receiving facilities, transportation equipment, and transportation routes. Examples of this type of information include waste generation rates and initial waste inventories for each source or storage location, annual waste handling capacities at each treatment and disposal facility, transport packaging cost and capacities, shipping costs and transit times.

Results of the CLM include estimates of shipping schedules, transportation hardware requirements and transportation system costs. Costs are reported in terms of the resulting cash flow and levelized unit shipping cost $\left(\$ / \mathrm{m}^{3}\right)$ for each transportation link and for the total transportation system. Capital costs for transportation hardware are also reported.

Results of the CLM are useful in several ways. In an absolute sense, the hardware requirements and cost estimates can be used to aid the development of plans to acquire and deploy the necessary transportation systems. In a relative sense, alternatives in the design and operation of transportation and waste handling facility components can be evaluated to measure their effect on the transportation system requirements. For example, waste package dimensions could be varied to measure changes in transportation charges, which can then be compared to the required changes in the handling facility capital costs. These costs can then be summed to determine the net system cost effect. 


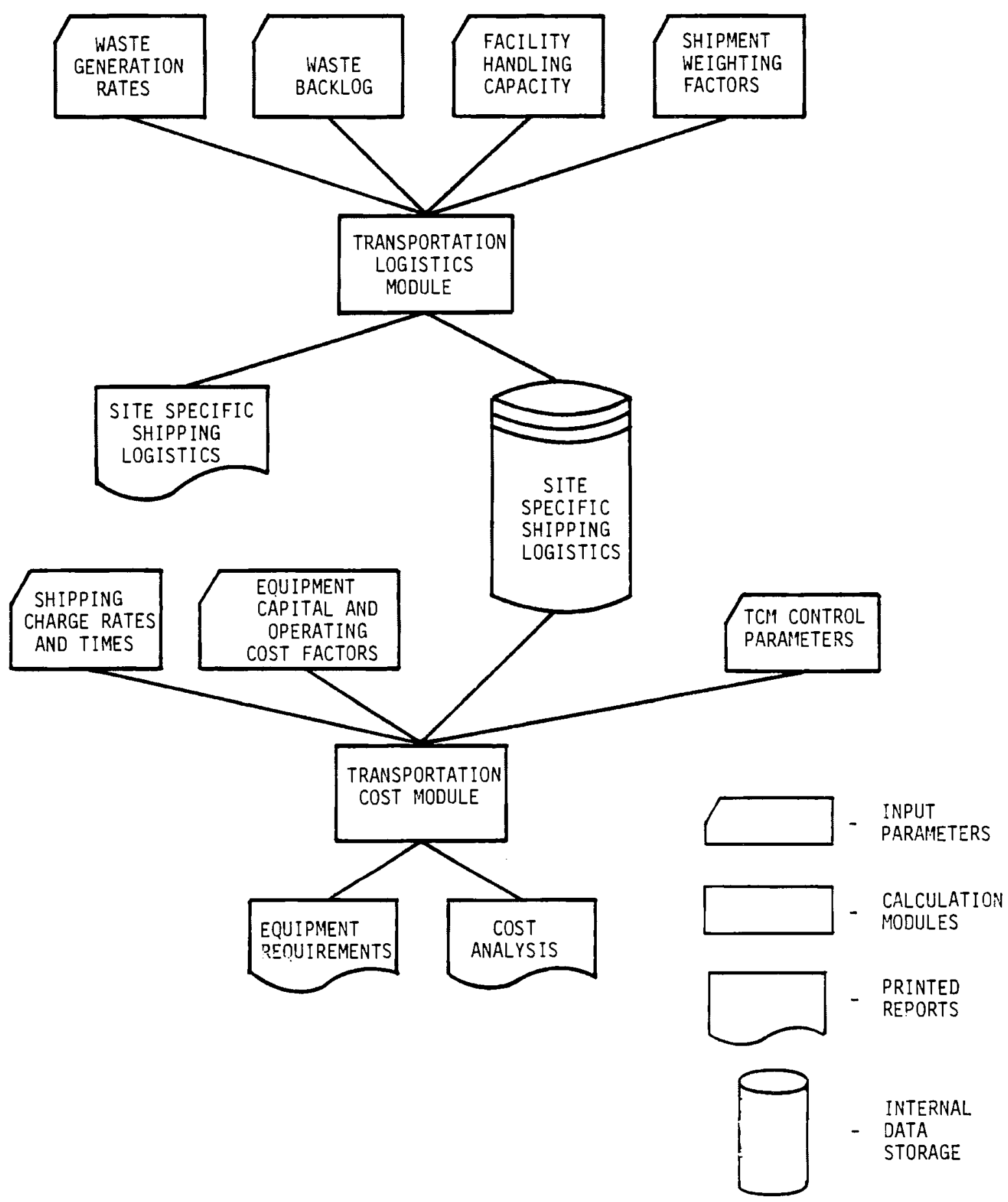

FIGURE 3.1. PNL Waste Transportation Cost and Logistics Model 


\subsection{TRANSPORTATION LOGISTICS MODULE}

The Transportation Logistics Module (TLM) provides estimates of the number of waste shipments for each origin-destination pair in a waste transportation network. The logistics results are then used in the Transportation cost Module (TCM) to estimate equipment requirements and provide a financial analysis of the transportation system.

The TLM can model either a single transportation phase, from waste source to disposal, or a two-phase transportation system, from source through a treatment process to disposal. The model allows for multiple waste categories, multiple waste source locations, multiple waste treatment locations, two transportation modes (rail and truck), and a single disposal site. Regional repositories can be studied by conducting multiple analyses. In the case where wastes are treated, it is assumed that all treated waste from a facility will be in a single type of canister resulting in a single treated waste category for each facility. If this assumption is not applicable to future analyses, additional treatment facilities may be defined in separate runs and combined with the rest of the analysis.

Information required by the TLM includes descriptions of waste sources, waste transportation equipment, waste treatment facilities, and waste disposal facilities. The waste source descriptions include initial backlog and waste generation rates over time for each waste category and each source location. The waste transportation equipment description consists of the amount of waste of each category that can be shipped in each packaging type for each shipment mode. The waste treatment facility description consists of a waste input volume capacity over time, and a waste volume conversion ratio. The waste disposal facility description is a waste volume input capacity over time.

The shipping schedule, in shipments per year for each waste category and each origin-destination combination, is calculated by the TLM. It is determined from the input capacity of the waste facility and the relative weighting factors. For example, if the annual facility input capacity is $1000 \mathrm{~m}^{3}$ and the relative waste output weight from origin $A$ and origin $B$ is 2 and 1 respectively then the model would calculate shipments of $670 \mathrm{~m}^{3}$ from site $A$ and $330 \mathrm{~m}^{3}$ from site $B$. Whenever the annual waste production plus the remaining waste backlog is 
insufficient to fill the allotted shipment from a source, the relative shipping weightings are modified. For example, in the above case, if the remaining back$\log$ from $A$ is $200 \mathrm{~m}^{3}$ and the annual production is $100 \mathrm{~m}^{3}$, but the backlog plus generation for $B$ is more than $700 \mathrm{~m}^{3}$, then the model would calculate shipments of $300 \mathrm{~m}^{3}$ from $A$ and $700 \mathrm{~m}^{3}$ from $B$. Thus, the estimated shipping schedule is a function of waste process capacity, relative shipping volumes, shipping packaging size, and the waste available at the origins.

The primary output of the TLM is a file of information to be used by the TCM. The file contains the waste system description parameters and the estimated waste shipment schedule. In addition, optional reports may also be prepared. These reports consist of waste origin summaries, waste treatment summaries, and waste disposal summary. The waste origin summary report contains waste back$\log$ and number of waste shipment for each year. The waste treatment facility summary report includes the treated waste backlog, the amount of untreated wastes received, and the number of shipments of treated waste for each year. The waste disposal summary report contains the amount of waste received each year and the accumulative waste disposal. Operating instructions and a list of input variables for the TLM is included in Appendix A.

\subsection{TRANSPORTATION COST MODULE}

The Transportation Cost Module (TCM) provides an estimate of the transport packaging requirements, capital costs, shipping and maintenance costs, and leve1ized unit costs for shipping defense waste via truck or rail. The results of the estimate may be presented for the entire system and/or for each individual origin-destination combination under consideration. Calculation capabilities of the TCM are described in this section.

The TCM utilizes a shipment logistics file, generated by the TLM (see Section 3.1), as a basis for its calculations. This file contains the volume and number of waste shipments as a function of year, transport packaging type, origin, destination, and transportation mode. Transport packaging types, transportation modes, and facility locations currently considered are those 
presented in Sections 4.0 and 5.0 for $\mathrm{CH}-$ TRU and HLDW respectively. The TCM assumes that the trucks and/or trains and transport packagings can be shared between each of the origin-destination combinations. Operating instructions and a 1 ist of input variables for the TCM are included in Appendix B.

\subsubsection{Transport Packaging Requirements}

Transport packaging requirements for truck or train shipments are calculated using the same methodology. Differences in parameters are used to consider mode specific characteristics; e.g., the number of packages per rail car and the number of cars per train.

To estimate the minimum number of transport packagings required it is necessary to first caiculate the number of round trips that a packaging can make in one year. This is determined by dividing the number of days per year that packaging can be used (hauling days) by the turnaround time (load, transit, unload and return time). If the number of hauling days per year is 250 , and the turnaround time is 10 days, then the number of round trips that a packaging can make in one year is 25 .

The total number of truck or train shipments necessary for each year, for any one origin-destination combination, can be determined by dividing the number of single package loads required (calculated in the TLM) by the number of packages per truck or train. If the volume of waste, from a given origindestination, requires 200 package loads in a year then the number of trips is equal to 200 for one package per trip. Only 100 trips would be required if two packages per trip are used.

The minimum number of transport packagings necessary, to move a given volume of waste in a year, is equal to the package loads required divided by the number of round trips a packaging can make. A volume of 200 packages loads requires 8 transport packagings at 25 trips per year.

\subsubsection{Capital Costs}

Capital costs, in this study, represent the purchases of transport packagings. The TCM permits capital expenditures to occur at anytime before the 
packagings are actually used. This allows the capital to be discounted and levelized to the correct point in time relative to the utilization (see Section 3.2.4).

Capital costs are calculated for the growth in packaging requirements in each year. This is done both for the individual origin-destination combinations and for the aggregate packaging requirements. The purpose of calculating the capital expenditures separately is to show each origin-destination's requirements if transport packagings are not shared between then, i.e., if each site must provide $i$ ts own packagings. Therefore, the sum of the capital expenditures for all of the origin-destination combinations will not, necessarily, equal the capital expenditure of the aggregate.

\subsubsection{Operating Costs}

The operating costs represent the expenses incurred for transporting the waste, loading and unloading the waste from the trailers or cars, and maintaining the transport packagings. These costs occur as a function of packing utilization.

The TCM divides the operating costs into three categories; shipping costs, handling costs, and maintenance costs.

Shipping Costs: The shipping costs are the fees charged by the carrier to transport the waste from the origin to the destination and return the empty packagings. These costs are based on a variety of parameters and are described in detail in Section 4.4 for CH-TRU and Section 5.4 for HLDW. In general, these costs are a function of the yearly shipping volume, the mode of transport (truck or train), the owner of the transport packagings, the distance traveled, and the tariffs negotiated.

Handling Costs: The handling costs represent the expenses associated with the loading and unloading of the truck trailers or rail cars at the origins and destinations. These costs are a direct function of the number of shipments per year and are calculated by multiplying the number of shipments by the handling charge per shipment. 
Maintenance Costs: Certain maintenance costs may be necessary over the life of the transport packagings. These include making repairs to damaged equipment, routine replacement of worn parts, and modifications to upgrade design.

The results of the transport packaging requirement calculations represents a minimum requirement. This minimum requirement means that al1 packagings are in constant utilization. Because of this, the maintenance charges can be expressed as a function of the number of packagings in use, i.e., the maintenance costs are equal to the number of packagings in use, times the packaging maintenance charge.

\subsubsection{Levelized Unit Costs}

The levelized unit cost methodology translates annual operating costs into an equivalent single unit cost in constant dollars over the life of the systems. The unit cost is the cost per unit of waste shipped sufficient to pay any interest charges on debt, pay all operating expenses, earn a specified return on outstanding capital (if applicable), and recover the capital over the life of the investment. By using the proper discount rate, the analysis can be performed in constant dollars rather than current dollars, where inflation must be considered.

Levelized unit costs are the sum of the present value costs divided by the sum of the present value waste shipping volume. Levelized unit cost is a single value for each waste form and waste management scenario. It is defined as follows:

$$
u=\frac{\sum_{t}\left(\frac{1}{1+r}\right)^{t}\left(c_{t}+0_{t}\right)}{\sum_{t}\left(\frac{1}{1+r}\right)^{t} w_{t}}
$$

where $u=$ levelized unit cost

$t=$ time period

$r=$ discount rate

$w_{t}=$ volume of waste shipped in period $t$

$c_{t}=$ capital expenditure in period $t$

$0_{t}=$ operating costs in period $t$. 
Levelized costs can also be interpreted as the unit charge that would exactly recover the capital and operating expenses if the interest rate is equal to the rate used in the present value calculation. Discount rates of $0 \%$ and $10 \%$ were used in the analysis to indicate the cost impact in terms of constant doliars or the higher rates of return required by private industry.

Since this study deals onty with defense wastes, costs are strictly government expenses with no attendent revenues. Therefore, it may seem more appropriate to consider only the sum of the present worth expenditures. However, by using the levelized unit cost, scenarios with different waste shipping schedules may be compared directly. 


\subsection{CONTACT-HANDLED DEFENSE WASTE TRANSPORTATION}

This section describes the cost and logistics analysis for contact-handled defense transuranic wastes. Separate discussions are provided for untreated contact-handled TRU (CH-TRU) and processed contact-handled TRU (PTRU) wastes. The section is divided into five subsections; waste descriptions (4.1), $\mathrm{CH}-\mathrm{TRU}$ and PTRU transportation systems (4.2), alternatives considered in this analys is (4.3) shipping casks and transit times (4.4) and results (4.5).

\subsection{CONTACT-HANDLED DEFENSE WASTE DESCRIPTIONS}

Volumes and canisters for $\mathrm{CH}$-TRU wastes and treatment processes and canisters for PTRU wastes are described in this sub-section.

\subsubsection{CH-TRU Waste Volumes}

CH-TRU wastes are produced from processes involving transuranic materials. Major producers of defense $\mathrm{CH}$-TRU wastes include the Hanford facilities near Richland, Washington, the Rocky Flats plant near Denver, Colorado, and Los Alamos National Laboratory (LANL) in northern New Mexico. Other waste producers are Argonne National Laboratory (ANL), Oak Ridge National Laboratory (ORNL), Mound Laboratory, Savannah River Plant (SRP), Nevada Test Site (NTS), Bettis Atomic Power Laboratory, and the Idaho National Engineering Laboratory (INEL). Figure 4.1 shows the location of these ten facilities, which generate the major portion of TRU wastes. Other waste-generating facilities exist, but are small contributors relative to the sites listed.

There are five general types of CH-TRU wastes: newly generated wastes, surface stored wastes, buried wastes, contaminated soil, and decontamination and decommissioning (D\&D) wastes. Estimates of the waste volumes in buried and surface storage modes used in this study are presented in Tables 4.1 and 4.2. The volume of D\&D wastes is highly dependent on future decommissioning policies and techniques, and has therefore not been included in this analysis. Recent updates to waste volume estimates indicate the projected volume of surface stored wastes in the year 2000 will be about 4\% lower than volumes used in this study (DOE 1981). This is about $1 \%$ of total $\mathrm{CH}$-TRU volumes and would have a 


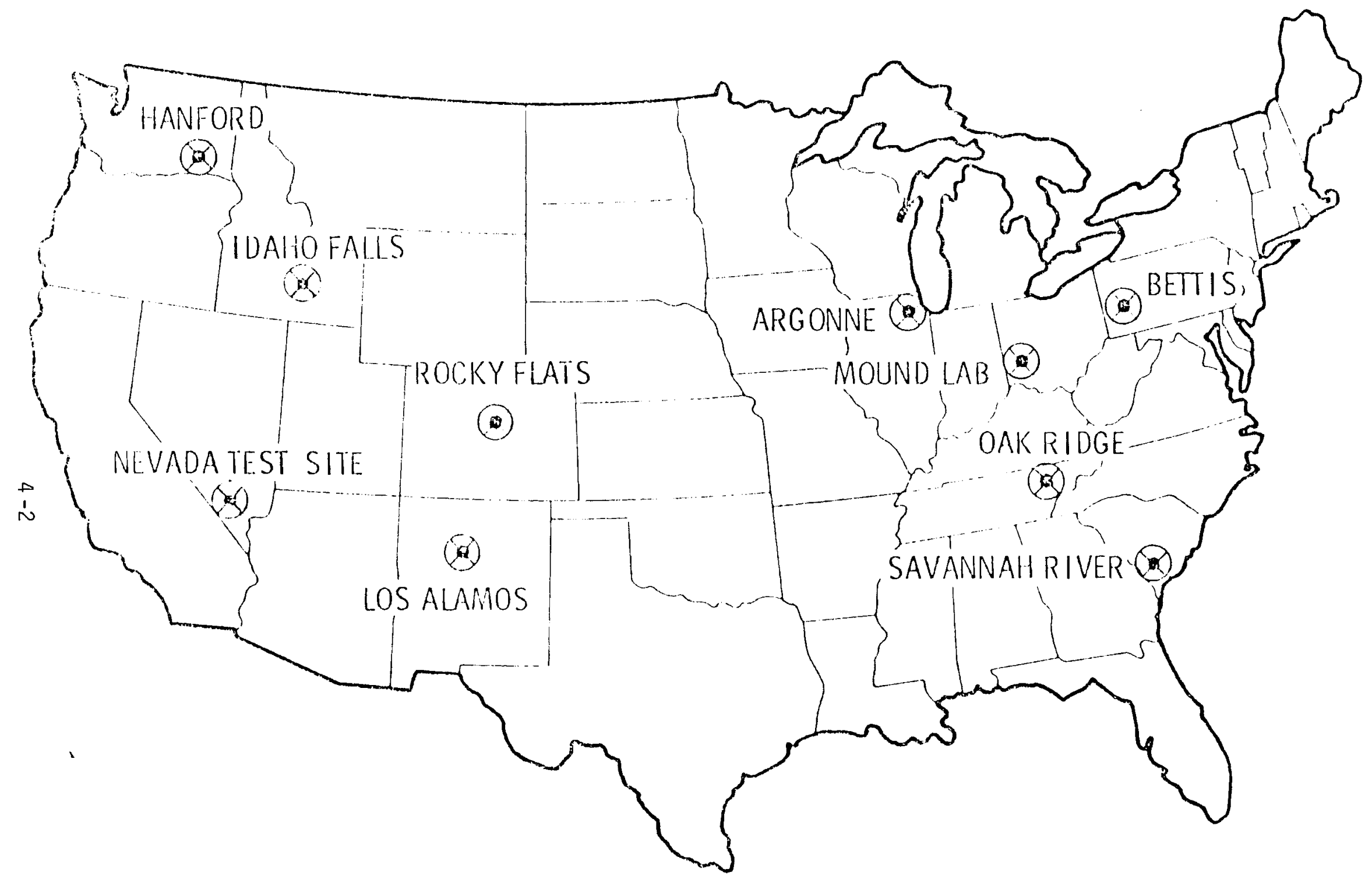

FIGURE 4.1. Locations of Facilities Generating and Storing Defense CH-TRU Wastes 
TABLE 4.1. Estimated Volumes of Defense CH-TRU Wastes in Surface Storage ${ }^{(a)}$

\begin{tabular}{|c|c|c|c|c|c|c|c|c|c|c|c|c|c|}
\hline Fiscal rear & 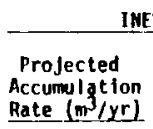 & $\begin{array}{l}\text { Accumilated } \\
\text { Yolume (ar) } \\
\text { (End of } \\
\text { Pertod) }\end{array}$ & 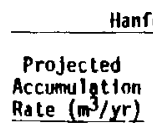 & $\begin{array}{l}\text { ord } \\
\text { Accumulates } \\
\text { Volume (m) } \\
\text { (End of } \\
\text { Perfod) } \\
\end{array}$ & $\begin{array}{l}\text { Projected } \\
\text { Accumulgtion } \\
\text { Rate (m } / y r)\end{array}$ & $\begin{array}{l}\text { Accumulated } \\
\text { Yolume (m3) } \\
\text { (End of } \\
\text { Perlod) }\end{array}$ & 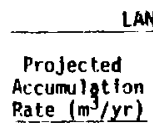 & $\begin{array}{l}\text { Accumulated } \\
\text { Volume (m) } \\
\text { (Fnd of } \\
\text { Pertod) }\end{array}$ & $\begin{array}{l}\text { ORn } \\
\text { Projected } \\
\text { Accumulgtion } \\
\text { Ratee }\left(\mathrm{m}^{3} / \mathrm{yr}\right)\end{array}$ & $\begin{array}{l}\text { Accumulated } \\
\text { Volume (m3) } \\
\text { (End of } \\
\text { Perlod) }\end{array}$ & $\begin{array}{l}\text { HI } \\
\text { Projected } \\
\text { Accumu I tion } \\
\text { Rate }\left(\mathrm{m}^{3} / y r\right)\end{array}$ & $\begin{array}{l}5 \\
\text { Accuntal ated } \\
\text { Volume (n) } \\
\text { (End of } \\
\text { Period) }\end{array}$ & $\begin{array}{l}\text { Total Accumulated } \\
\left.\text { Volume ( } \mathrm{m}^{3}\right) \\
\text { (End of Pertod) }\end{array}$ \\
\hline as of $10 / 1 / 79$ & -.. & 40,120 & $\ldots$ & 8,038 & ... & 2,365 & $\ldots$ & 3.528 & -.- & 384 &.-- & 213 & 54,678 \\
\hline 1980 & 2.585 & 42,705 & 679 & 8,717 & 146 & 2,511 & 1,418 & 4,946 & 35 & 419 & 31.9 & 275 & 59.573 \\
\hline 1981 & 2.658 & 45,363 & 136 & 9,453 & 146 & 2,657 & 568 & 5,514 & 11.8 & 491 & 31.8 & 307 & 63,785 \\
\hline 1982 & 2,725 & 48,088 & 255 & 9.708 & 146 & 2,803 & 568 & 6,082 & 11.8 & 563 & 31.8 & 338 & 67.582 \\
\hline 1983 & 2.882 & 50,970 & 227 & 9,935 & 146 & 2,949 & 568 & 6,650 & 11.8 & 634 & 31.8 & 370 & 71,508 \\
\hline 1984 & 3,035 & 54,005 & 1048 & 10,983 & 146 & 3,095 & 568 & 7.218 & 71.8 & 706 & 31.8 & 402 & 76,109 \\
\hline 1985 & 2,177 & 56,782 & 1056 & 12,039 & 146 & 3,241 & 568 & 1,786 & 71.8 & 778 & 31.8 & 434 & 81.060 \\
\hline $1986-1990$ & 2,152 & 67,542 & 1056 & 17,319 & 146 & 3,971 & 568 & 10,626 & 71.8 & 1,137 & 31.8 & 593 & $101.18 \mathrm{R}$ \\
\hline $1991-2000$ & 1,914 & 86,682 & 1056 & 27,879 & 146 & 5,431 & 568 & 16,306 & 11.8 & 1,855 & $31 . \mathrm{A}$ & ו11 & 139,064 \\
\hline
\end{tabular}

(a) Data from OPNL/TM-7320, June 30, 1980, totals have excess signifirant rigures fer consistency, see lable 4.1 for uncertainty estimates on 
TABLE 4.2. Estimated Volumes of Buried Defense CH-TRU Wastes (a)

\begin{tabular}{|c|c|c|}
\hline Site & $\begin{array}{l}\text { Solid Wastes } \\
\text { and Associated } \\
\text { Contaminated } \\
\text { Subsurfaçe } \\
\text { Volume }\left(\mathrm{m}^{3}\right) \\
\end{array}$ & $\begin{array}{l}\text { Solid Waste } \\
\text { Emplaced }\left(\mathrm{m}^{3}\right) \\
\end{array}$ \\
\hline INEL & 212,859 & 57,113 \\
\hline Hanford & 291,103 & 211,251 \\
\hline SRL & 61,000 & 27,270 \\
\hline LANL & 28,300 & 11,485 \\
\hline ORNL & 167,072 & 6,229 \\
\hline NTS & 5,700 & 5,700 \\
\hline Total & 766,034 & 319,048 \\
\hline
\end{tabular}

(a) Data from ORNL/TM-7320, June 30, 1980; totals have excess significant figures for consistency, see Table 3.4 for uncertainty estimates on the values.

small effect on the results of this study. Buried waste volumes are currently believed (DOE 1981) to be $14 \%$ below those used in this study. However, estimates of the total contaminated subsurface volume have an estimated range of $34,600-2,867,000 \mathrm{~m}^{3}$. This range is $55 \%$ to $274 \%$ of the values used in this study. Refinement of waste volume estimates will be required prior to the development of accurate logistics estimates for these wastes.

Contaminated soil arises from two sources. The first is from retrieval of buried wastes. This volume was considered to be recovered with the buried wastes. The second source is soil used to adsorb TRU nuclides from liquid waste streams. Estimates for this second source of contaminated soil are 20 times greater than for buried wastes plus associated contaminated soi1, or 14 million $\mathrm{m}^{3}$. Retrieval techniques for contaminated soil were not considered in this study.

The projection of future stored $\mathrm{CH}$-TRU waste volumes requires an estimation of site accumulation rates and storage inventories which have been included in 
Table 4.1. No additional buried wastes are expected to accumulate in the future because a11 TRU wastes are now required to be stored in such a way that they can be readily retrieved. The accumulation rates do not reflect volume changes that could result from incineration, compaction, or immobilization of the combustible portion of the wastes.

Several CH-TRU waste producers transport wastes to other facilities for storage. Projected accumulation rates for the INEL on Table 4.1 include wastes shipped from ANL (East), Bettis Atomic Power Laboratory, Mound Laboratories, and Rocky Flats, as well as the CH-TRU wastes produced at the INEL. The estimated fraction of the projected accumulation rate for the INEL originating at other sites is provided in Table 4.3. Shipments of wastes from these primary waste generating sites to INEL for storage were ignored in this analysis since the transportation requirements already exists. Shipments from these sites after the repository opens (1997) or after facilities begin treatment (1990), are included in the analysis. Additional waste producers transport CH-TRU wastes to storage facilities; however, because the small quantities of wastes from these other producers are minor, their shipments were excluded from this study.

TABLE 4.3. Origin of CH-TRU Wastes in Surface Storage at the INEL

\begin{tabular}{|c|c|}
\hline Origin & $\begin{array}{l}\text { Percentage of } \\
\text { INEL Projected } \\
\text { Storage Volumes } \\
\end{array}$ \\
\hline Rocky Flats (a) & 60 \\
\hline $\mathrm{ANL}^{(b)}$ & 3 \\
\hline Bettis (b) & 2 \\
\hline Mound (b) & 9 \\
\hline $\operatorname{INEL}^{(b)}$ & 26 \\
\hline Tota1 & 100 \\
\hline $\begin{array}{l}\text { (a) Data from } \\
\text { (b) Based on } \\
\text { November } 1\end{array}$ & $\begin{array}{l}\text { NL/TM-7320, } 1980 . \\
\text { a from Shefelbine } \\
8, \text { p. } 11 .\end{array}$ \\
\hline
\end{tabular}


Uncertainty in estimates of future $\mathrm{CH}$-TRU waste volumes increases with the time of the projection. The uncertainties of the estimated volumes of $\mathrm{CH}-\mathrm{TRU}$ wastes used in this study are shown in Table 4.4. Surface-stored wastes are the best characterized. Much less is known about buried wastes; these materials consist of wastes containing TRU nuclides and other wastes contaminated with low levels of radioactivity that have been buried in landfill operations. Though a11 of the buried wastes are currently considered to be CH-TRU wastes due to the intermixing of the waste types, a portion may be in concentrations less than the $10 \mathrm{nCi} / \mathrm{g}$ definition of TRU waste. If the wastes can be sorted into TRU and non-TRU components, transportation requirements to a TRU waste repository would be reduced. Assay systems for waste sorting are currently under development by the Transuranic Waste Systems Office at the Rocky Flats plant. Additional uncertainty in buried waste volumes arises when considering possible retrieval operations which may result in a total volume of contaminated material that is up to twice the original waste volume.

TABLE 4.4. Uncertainties for Estimated Volumes of $\mathrm{CH}-\mathrm{TRU}$ Wastes (a)

\begin{tabular}{lcccc} 
Site & $\begin{array}{c}\text { Buried } \\
\text { Wastes }(\%)\end{array}$ & $\begin{array}{c}\text { Surface } \\
\text { Stored Wastes }(\%)\end{array}$ & $\begin{array}{c}\text { Projected } \\
\text { Generation } \\
\text { Rates }(\%)\end{array}$ \\
\cline { 1 - 1 } INEL & $+300,-30$ & \pm 3 & $+20,-40$ \\
Hanford & $+200,-50$ & \pm 5 & $+25,-0$ \\
SRL & $+100,-20$ & \pm 5 & $+50,-50$ \\
LANL & $+50,-50$ & \pm 5 & $+150,-25$ \\
ORNL & $+20,-20$ & \pm 5 & $+25,-25$ \\
NTS & $+50,-75$ & \pm 5 & $+25,-25$
\end{tabular}

(a) Data from ORNL/TM-7320, 1980.

\subsubsection{CH-TRU Waste Canisters}

Contact-handled TRU wastes exist in a number of physical forms ranging from unprocessed general trash to concrete-stabilized sludge. Many kinds of waste canisters have been used and are currently being used to contain and store these wastes. Prior to 1970 , most of the $\mathrm{CH}$-TRU wastes were packaged in 210-7iter (55-gallon) drums. Although drums are still widely used, the 
present trend is towards the use of large plywood and metal boxes. These boxes not only cost less than the drums on a unit volume basis, but also make more efficient use of storage volume.

A prel iminary assessment of the types of canisters currently used for CH-TRU wastes has been made by Shefelbine (1978). Table 4.51 ists CH-TRU waste canisters by size, weight, stored volume and package origin. Over ninety percent of these wastes are stored in 210-1iter (55-gallon) steel drums and in fiberglass reinforced polyester (FRP) plywood boxes of various dimensions. The most commonly used FRP plywood box is the $1.2 \mathrm{~m} \times 1.2 \mathrm{~m} \times 2.1 \mathrm{~m}$ ( $4 \mathrm{ft} \times 4 \mathrm{ft} \times$ $7 \mathrm{ft}$ ) box developed at Rocky Flats.

A replacement canister for the Rocky Flats box, called the Modular Box, is being developed at Rocky Flats. This box is approximately $1.9 \mathrm{~m} \times 1.3 \mathrm{~m} \times$ $0.94 \mathrm{~m}$ (75 in. $\times 51$ in. $\times 37$ in.) and can also be used to overpack 55-gallon drums in a 6-pack array. The Modular Box is constructed of metal.

For the purpose of this study, three canisters were considered for untreated CH-TRU wastes: the 210-liter (55-gallon) drum, the Rocky Flats box, and the Modular Box. The 210-1iter drums may be transported singly or banded together in a 6-pack unit or placed in the Modular Box. Table 4.6 lists the dimensions and waste volumes for each of these packages. A11 untreated wastes are assumed to be packaged in 210-1iter (55-ga110n) drums or Rocky Flats boxes unti1 1982 when the Modular Box is to be introduced. After this date, waste types currently placed in Rocky Flats boxes are assumed to be packaged in the Modular Box.

The fraction of the CH-TRU stored wastes contained in drums or boxes is dependent on the waste origin. Where no estimate was available for the drum/ box waste volume mix, the wastes were assumed to be packaged and stored in drums. Since drums are the least efficient package in terms of shipment volume usage, the resulting analysis is conservative. For analysis in this report, half of the stored wastes at Idaho were assumed to be in boxes (Shefelbine 1978) with all other sites using drums. Two thirds of the future waste production from Rocky Flats will be packaged in boxes (WIPP EIS) and all other sites are assumed to use drums. 


\section{TABLE 4.5. Types of Canisters Used in $\mathrm{CH}$-TRU Waste}

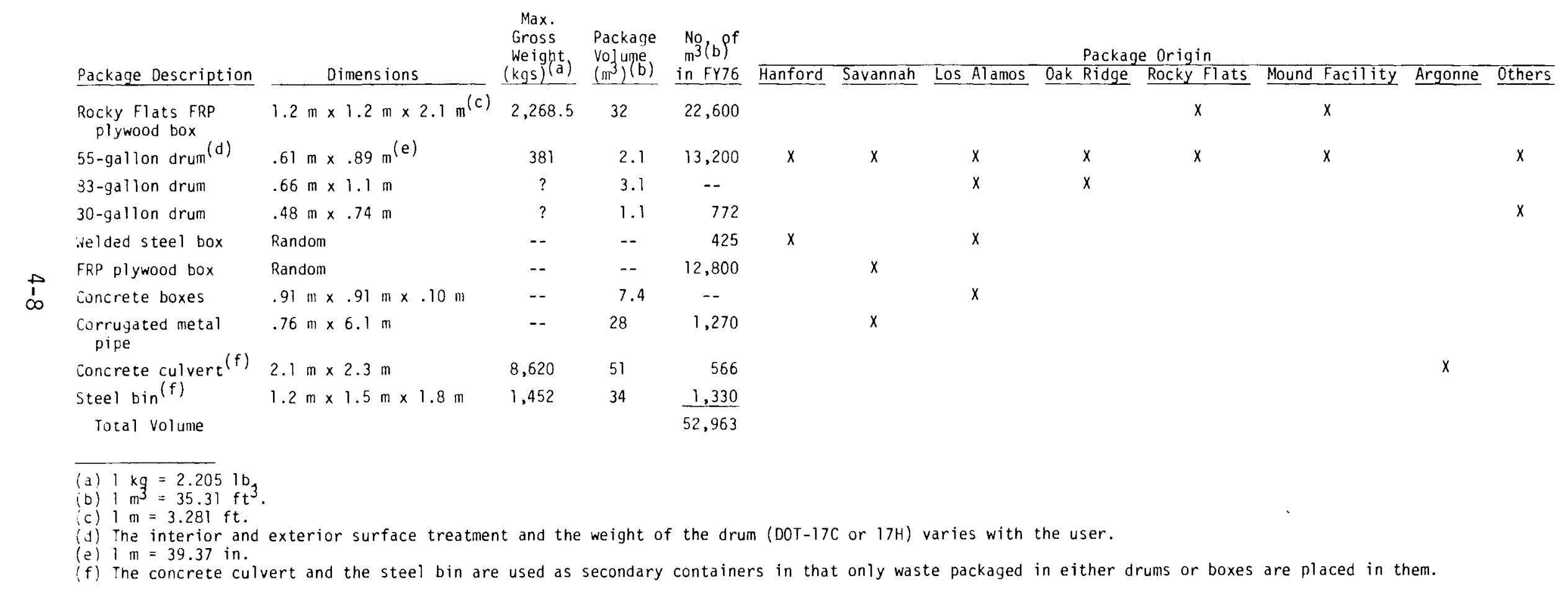


TABLE 4.6. CH-TRU Waste Packages

\begin{tabular}{|c|c|c|}
\hline Package & $\begin{array}{l}\text { Package Dimensions } \\
\text { (Exterior) }\end{array}$ & $\begin{array}{l}\text { Waste Volume } \\
\text { (Interior) }\end{array}$ \\
\hline 210-1iter Drum & $\begin{array}{l}0.61 \mathrm{~m} \mathrm{dia} \times 0.89 \mathrm{ml} \\
(24 \mathrm{in} . \times 35 \text { in. })\end{array}$ & $\begin{array}{l}0.21 \mathrm{~m}^{3} \\
\left(7.42 \mathrm{ft}^{3}\right)\end{array}$ \\
\hline Rocky Flats Box & $\begin{array}{r}1.2 \mathrm{~m} \times 1.2 \mathrm{~m} \times 2.1 \mathrm{~m} \\
(4 \mathrm{ft} \times 4 \mathrm{ft} \times 7 \mathrm{ft})\end{array}$ & $\begin{array}{l}2.55 \mathrm{~m}^{3} \\
\left(90 \mathrm{ft}^{3}\right)\end{array}$ \\
\hline Modular Box & $\begin{array}{l}1.9 \mathrm{~m} \times 1.3 \mathrm{~m} \times 0.94 \mathrm{~m} \\
(75 \text { in. } \times 51 \text { in. } \times 37 \text { in. })\end{array}$ & $\begin{array}{l}2.12 \mathrm{~m}^{3} \\
\left(75 \mathrm{ft}^{3}\right)\end{array}$ \\
\hline
\end{tabular}

If it is considered necessary to exhume, repackage and ship buried wastes, both drums and boxes may be used. At this time, however, little information is available concerning the drum/box ratio resulting from the packaging of buried wastes. A recent study by the INEL (ID0-0081, p. 10-10) indicates that if exhumation and repackaging are required, all buried wastes would be packaged in new 210-1iter drums with 90-mil polyethylene liners. For waste alternatives in this study which include the retrieval, repackaging and shipment of buried wastes, therefore, the conservative assumption has been made that all repackaged buried wastes are to be placed in drums.

\subsubsection{CH-TRU Waste Treatment Processes and Treated Waste Forms}

Processing or repackaging of contact-handled defense wastes is being considered as part of current waste isolation programs as a means of improving radionuclide retention under normal and accident conditions during transportation, emplacement in a waste repository and long-term isolation from the biosphere. Repackaging, as a means of mitigating the effects of defective or failed waste canisters and to upgrade canisters of inadequate design, has been proposed in DOE/ET-0081 for stored TRU wastes at INEL. Processes to incinerate TRU wastes and then convert the residual to glass, cement or slagged waste forms are under development by the Transuranic Waste Systems Office (TWSO) at the Rocky Flats Plant.

Repackaging of wastes has advantages in controlling radionuclide releases during the operational phase of a waste repository. Upgrading of the canisters 
may reduce potential accidental releases during this phase. Long term waste performance in a waste disposal facility will probably not be significantly altered by repackaging using conventional waste containers.

CH-TRU waste form disposal characteristics can be improved by conversion to leach resistant, noncombustible solids. Processes are currently under development to produce glass, cement and slag waste forms. At the present time, the slag form appears to be representative and was used as the reference treated form in this study. Other waste forms with densities, radionuclide content and leach resistance would have transportation cost and logistics results related to slag by their relative waste volume change during processing. Engineered waste forms, in addition to the operational and long-term isolation advantages have potential for reduced transportation packaging requirements compared to those for untreated $\mathrm{CH}-\mathrm{TRU}$ wastes.

Programs are underway at the TWSO, the INEL, the TTC and the PNL to characterize in detail the performance of waste slags during transportation and long-term isolation. Preliminary measurements indicate that the waste form has a typical density of $2800 \mathrm{~kg} / \mathrm{m}^{3}$ and half the volume of the untreated waste. Molten slag can be poured into disposable molds or canisters that serve as a containment barrier during repository emplacement and retrievable storage. If the treatment option is adopted, treatment facilities are assumed to start operations in 1990 for this analysis.

\subsection{CONTACT-HANDLED DEFENSE WASTE TRANSPORTATION SYSTEMS}

Transportation system requirements differ for untreated $\mathrm{CH}-\mathrm{TRU}$ and PTRU wastes. Existing systems and conceptual systems under development at the TTC and the PNL for these materials are described in this section.

\subsubsection{CH-TRU Shipping System}

Three types of waste transportation systems were considered in this study for the transport of untreated $\mathrm{CH}$-TRU wastes: the Super Tiger ${ }^{\circledR}$ packaging, the ATMX railcar, and TRUPACT packaging. Both the Super Tiger ${ }^{\circledast}$ and the ATMX 
systems are currently in service under special licensing exemptions from the U.S. Department of Transportation to ship radioactive material. The TRUPACT packaging along with the Modular Box and 6-pack (i.e. 6 210- $\ell$ drums bound together) concepts are being developed to provide a generally licensable system with greater efficiency in handling and transporting $\mathrm{CH}$-TRU wastes. Table 4.7 lists the estimated packaging costs, lifetimes, and maintenance expenses.

TABLE 4.7. Assumed Cost and Lifetime of CH-TRU Shipping Packagings

\begin{tabular}{|c|c|c|c|}
\hline & ATMX & Super Tiger ${ }^{\circledR}$ & TRUPACT \\
\hline Lifetime (years) & 30 & 20 & 20 \\
\hline \multicolumn{4}{|l|}{ Costs $(\$)$} \\
\hline Capital & 183,000 & 100,000 & 200,000 \\
\hline 5-Year Overhaul & -- & 10,000 & 10,000 \\
\hline Annual Maintenance & 2,000 & 500 & 500 \\
\hline
\end{tabular}

The ATMX railcar is currently being used to ship CH-TRU wastes from Rocky Flats to Idaho Falls. It is fully enclosed and massive; the underframe is a one-piece steel casting which is reinforced by welded steel plates and the superstructure is constructed from steel armor, cross-braced and heavily reinforced. The interior dimensions of the car are $2.7 \mathrm{~m} \times 2.7 \mathrm{~m} \times 15.2 \mathrm{~m}$ ( $9 \mathrm{ft} \times 9 \mathrm{ft} \times 50 \mathrm{ft}$ ) and it has a load 1 imit of 45.8 metric tons (101,000 1bs) (Adcock 1970). The waste package capacity and weight of the ATMX are shown in Table 4.8. To carry drums, two standard cargo containers are utilized to meet requirements of the ATMX operating license, reduce loading and handling time, and to provide adequate anchorage for drums within the car. Each cargo container usually holds seventy 210-1iter drums of waste. Cargo containers are not required in ATMX railcars modified to transport Rocky Flats boxes. The ATMX system carrying drums or boxes forms a containment system of multiple barriers. Though the ATMX was not designed to carry Modular Boxes or drums in the 6-pack array, an estimate of the capacity for these waste packages has been made and is shown in Table 4.8 for comparison. 
TABLE 4.8. Shipping Modes and Waste Capacities of CH-TRU Shipping Packagings

\begin{tabular}{|c|c|c|c|c|}
\hline \multirow[b]{2}{*}{ Shipping Mode } & \multirow{2}{*}{$\frac{\text { ATMX }}{\text { Rail }}$} & \multirow{2}{*}{$\frac{\text { Super Tiger }{ }^{\circledR}}{\text { Truck }}$} & \multicolumn{2}{|c|}{ TRUPACT } \\
\hline & & & $\operatorname{Rail}(a)$ & Truck \\
\hline - Loose Drums & 140 & 42 & 96 & 36 \\
\hline - 6-Pack Drum Units & 16 & 2 & 16 & 6 \\
\hline - RF Boxes & $24^{(b)}$ & 2 & 4 & 2 \\
\hline $\begin{array}{l}\text { - Modular Boxes } \\
\text { Shipping Weights (kgs) (c) }\end{array}$ & 16 & 2 & 16 & 6 \\
\hline - Empty & $56,300^{(d)}$ & 7,700 & 21,800 & 10,000 \\
\hline - Payload Limit & 45,800 & 13,600 & 38,200 & 12,700 \\
\hline $\begin{array}{l}\text { (a) Two TRUPACT packagings } \\
\text { capacity per packaging } \\
\text { etc. } \\
\text { (b) No cargo containers used } \\
\text { (c) } 1 \mathrm{~kg}=2.2051 \mathrm{~b} \text {. } \\
\text { (d) Includes railcar and } 2 \text { s }\end{array}$ & $\begin{array}{l}\text { are shipped } \\
=\text { Eight 6-pa } \\
\text {. }\end{array}$ & $\begin{array}{l}\text { per railcar; } \\
\text { ack drums, or }\end{array}$ & $\begin{array}{l}\text { i.e., was } \\
48 \text { loose }\end{array}$ & $\begin{array}{l}\text { te } \\
\text { drums, }\end{array}$ \\
\hline
\end{tabular}

The Super Tiger ${ }^{\otimes}$ packaging has been used for both truck and rail shipments. It is presently the only packaging used for transporting $\mathrm{CH}$-TRU wastes by truck. The Super Tiger has the outside dimensions of a standard cargo container, $2.4 \mathrm{~m}$ $\times 2.4 \mathrm{~m} \times 6.1 \mathrm{~m}(8 \mathrm{ft} \times 8 \mathrm{ft} \times 20 \mathrm{ft})$, and is constructed from two rectangular steel shells separated with fire-retardant polyurethane foam. The steel inner she11 is approximately $1.8 \mathrm{~m} \times 1.8 \mathrm{~m} \times 4.3 \mathrm{~m}$ (6 $\mathrm{ft} \times 6 \mathrm{ft} \times 14 \mathrm{ft}$ ) (Hansen 1970). The Super Tiger ${ }^{\otimes}$ can be handled and shipped in the same manner as any standardized shipping container. It can accommodate forty-two 210-1iter drums of waste and has a maximum payload of 13.6 megagrams $(30,0001 \mathrm{bs})$. The capacity of the Super Tiger for other types of waste packages is listed in Table 4.8 .

TRUPACT (Eakes et al. 1980) packagings are under development for both truck and rail Type $B$ shipments. Type $B$ packages are designed to retain their contents under accident conditions. At the end of FY80, (a) the TRUPACT for

(a) Future design activities at the TTC may provide for a more efficient rail TRUPACT for other waste forms such as the Rocky Flats boxes. 
truck shipment was envisioned to have outside dimensions of approximately $2.0 \mathrm{~m}$ $\times 2.7 \mathrm{~m} \times 7.5 \mathrm{~m}(6.5 \mathrm{ft} \times 9 \mathrm{ft} \times 24.5 \mathrm{ft})$. It has been designed to hold thirty-six 210-1iter drums (six 6-packs) or six Modular Boxes. For rail shipments, the TRUPACT is envisioned to have outside dimensions of $2.7 \mathrm{~m} \times 3.0 \mathrm{~m}$ $\times 7.3 \mathrm{~m}(8.8 \mathrm{ft} \times 10 \mathrm{ft} \times 24 \mathrm{ft})$ and can contain forty-eight 210-1iter drums or eight Modular Boxes. Two rail TRUPACT packages can be shipped per flatcar. Though the TRUPACT is not being designed to carry Rocky Flat boxes, it is estimated that two boxes could be transported by either size TRUPACT shipping packaging. FY81 design activities will provide for a more efficient rail TRUPACT for other waste forms such as the Rocky Flats boxes, if possible. The estimated TRUPACT weight and payload limits are compared to the ATMX and Super Tiger ${ }^{\circledR}$ in Table 4.8 .

\subsubsection{PTRU Waste Shipping System}

Conceptual designs for packagings for the shipment of PTRU wastes are under development at PNL under the sponsorship of the TTC. Uncertainties currently exist in all phases of $\mathrm{CH}$-TRU treatment, transportation and disposal systems that may impact transportation hardware requirements. In addition, revisions to transportation regulations are being considered by the NRC and DOT that could impact PTRU transportation system design. Proposed revisions to transportation regulations have been published in the Federal Register (Federal Register, January 8, 1979 and August 17, 1979). For these reasons, PNL efforts were directed toward the evaluation of three classes of shipping packagings for PTRU wastes. These shipping container classes are Type B overpacks, Special Form capsules with Type A overpacks, and Low-Leve1 Solid materials. The repackaging in conventional canisters alternative is not considered in this section. Repackaged wastes could be shipped in systems described in Section 4.2 .1 .

Type B packages are extremely rugged systems capable of withstanding severe accidents taking no credit for the integrity of the waste form or the waste canisters. Two alternatives are being considered as an economic comparison for Type B designs: reusable packages that would carry PTRU wastes to the repository and be returned empty, and disposable packages that would be placed in the repository with the waste. Table 4.9 contains estimates of 
TABLE 4.9. Capacities of PTRU Shipments Using Type B Packagings

\begin{tabular}{|c|c|c|}
\hline Disposable Packagings & Truck & $\operatorname{Rai1}(a)$ \\
\hline Waste Volume $\left(\mathrm{m}^{3}\right)$ & 3.7 & 12. \\
\hline Shipment Weight $(\mathrm{kg})$ & 20,000 & 60,000 \\
\hline \multicolumn{3}{|l|}{ Reusable Packagings } \\
\hline \multicolumn{3}{|l|}{ Conceptual } \\
\hline Waste Volume $\left(\mathrm{m}^{3}\right)$ & 3.0 & 8.9 \\
\hline Shipment Weight $(\mathrm{kg})$ & 20,000 & 60,000 \\
\hline $\cos t$ & $\$ 260,000$ & $\$ 780,000$ \\
\hline
\end{tabular}

TRUPACT Packagings

$\begin{array}{lrc}\text { Waste Volume }\left(\mathrm{m}^{3}\right) & 3.75 & 12 . \\ \text { Shipment Weight }(\mathrm{kg}) & 22,700 & 60,000 \\ \text { Cost } & \$ 200,000 & \$ 400,000\end{array}$

(a) Two packages per shipment.

Type B shipment characteristics. TRUPACTs were assumed to be capable of carrying the higher density PTRU wastes. Capacities for transport of PTRU wastes were estimated based on weight limits only. Actual PTRU waste capacities of the TRUPACT could be lower depending on waste package dimensions.

Special-Form capsules in Type A overpacks must meet criteria similar to Type B packagings. Special-Form packaging, however, takes credit for structural aspects of the waste form and packaging. Costs, capacities and logistics for Special-Form capsules for PTRU wastes would be similar to those of disposable Type B packages.

Proposed requirements for Low-Level Solid material place restrictions on specific activity, structure and resistance of the waste forms to release of radionuclides during exposure to various environmental conditions (see Glossary). The reference slag in this study was assumed to meet these requirements. Shipping packagings for this material must meet tests similar to those for Type $A$ packages. The Low-Level Solids package is assumed to be disposable in this study. Table 4.10 contains characteristics of a Low-Level Solids shipment. 
TABLE 4.10. Capacities of PTRU Shipments in the Low-Leve1 Solids Classification

$\begin{array}{lrrr} & \text { Truck } & \text { Rail } \\ \text { Waste volume }\left(\mathrm{m}^{3}\right) & 6.3 & 20 \\ \text { Shipment Weight }(\mathrm{kg}) & 20,000 & 60,000\end{array}$

\subsection{ALTERNATIVES FOR CONTACT-HANDLED DEFENSE WASTE TREATMENT/SHIPMENT}

A large number of alternatives are currently being considered for storage, treatment and disposal of contact-handled defense wastes by the U.S. Department of Energy. Transportation demands and, therefore, logistics and costs are unique to each combination of alternatives. Thus, for this study, several combinations of waste management alternatives were studied to estimate the impact of alternatives in the future waste transportation system. The alternatives include:

- repository policy alternatives

- transportation systems alternatives

- buried waste retrieval policy alternatives

- treatment policy alternatives (PTRU production)

- facility siting strategy alternatives.

Two basic repository policies were considered in this study: one national repository and two or four regional repositories. National repository scenarios assume a single waste disposal facility at various locations in the U.S. Alternate locations for a single repository were the Southwest, Northwest, Mojave Desert or Central Rockies were considered. Regional repositories assumed multiple waste disposal facilities serving various sections of the U.S. Both fourregion and two-region cases were considered. The four-region case is shown in Figure 4.2. The two-region scenario postulated repositories in the Northwest and Northeast. Interregional waste shipments were not allowed in the regional repository scenarios. 


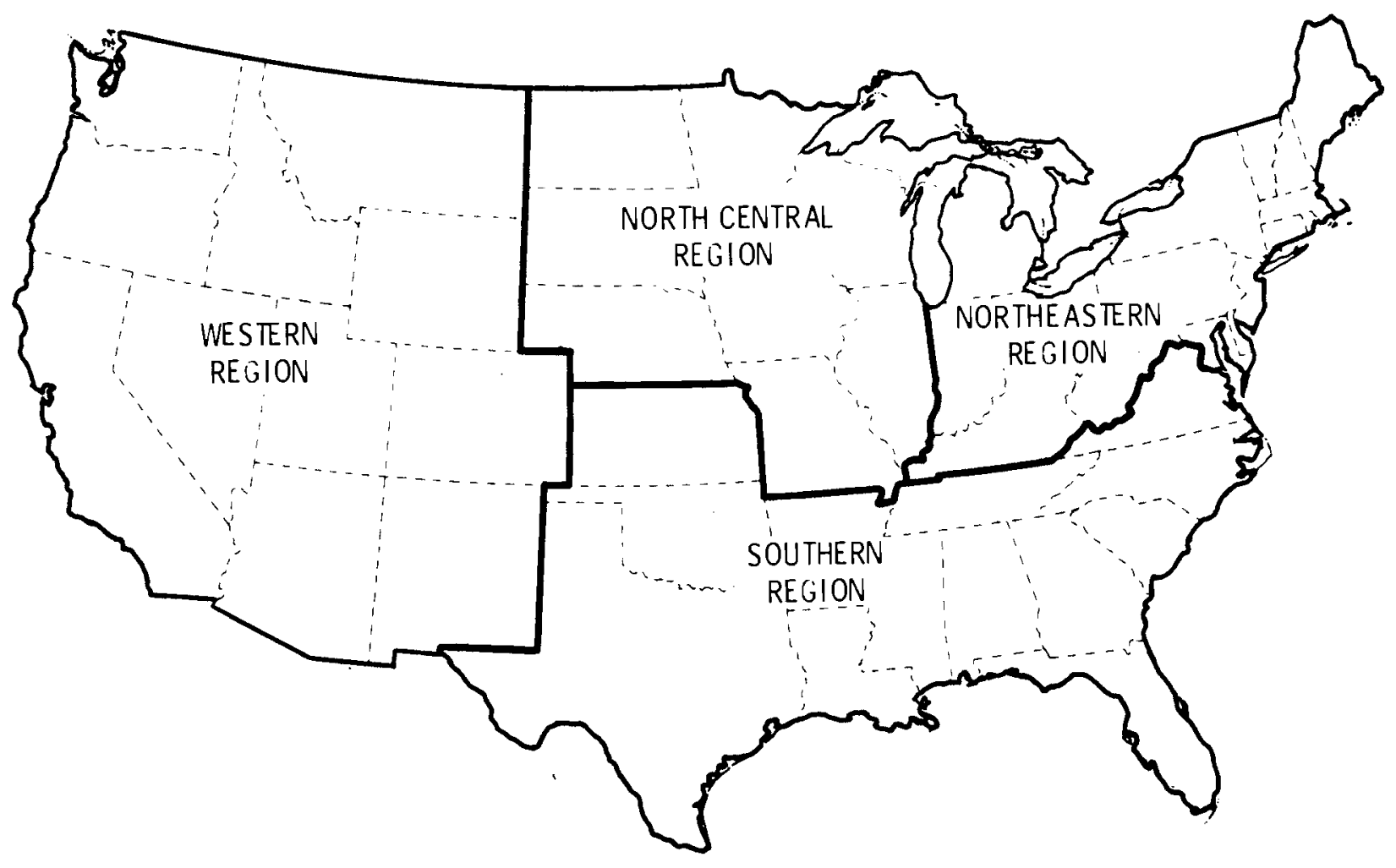

FIGURE 4.2 Map of Four Regions

The contact-handled defense waste transportation system alternatives considered were $\mathrm{CH}-\mathrm{TRU}$ shipping system, PTRU shipping system and transport mode. The $\mathrm{CH}-\mathrm{TRU}$ waste transportation systems alternatives considered were:

- Two sizes of TRUPACT packagings; one for rail and one for truck. Two railsize TRUPACTS are shipped on a rail car.

- Use of only the truck-size TRUPACT. Two or three of these packagings are shipped on a rail car.

- ATMX car for rail shipment and Super Tiger ${ }^{\circledR}$ for truck shipments.

- ATMX car for RF boxed waste and TRUPACT packagings for a1l other waste packages. 
The PTRU transportation system alternatives considered were:

- Waste in Low-Level Solids category

- Type B disposable overpacks

- Type B reusable overpacks

- TRUPACT packagings

The transport mode alternatives evaluated were:

- $75 \%$ rail, $25 \%$ truck

- $50 \%$ rail, 50\% truck

- A11 truck

Four $\mathrm{CH}$-TRU waste sources do not have rail service. Wastes generated at these sites were always shipped by truck. The four sites include Nevada Test Site, Los Alamos National Laboratory, Argonne National Laboratory, and Bettis Atomic Power Laboratory.

Three alternative $\mathrm{CH}$-TRU waste retrieval policies were considered in this study. The first included newly generated plus retrievably stored wastes. In the second alternative, buried wastes were added. The third alternative included newly generated, retrievably stored, buried, and the contaminated soil wastes.

Two $\mathrm{CH}-\mathrm{TRU}$ waste treatment policy alternatives were considered. The first policy allows for no treatment with $\mathrm{CH}$-TRU waste disposal directly into the repository. This case is logistically identical to locating treatment facilities at repositories. The second treatment policy assumes that the $\mathrm{CH}-\mathrm{TRU}$ wastes are treated and repackaged before emplacement in the repository. Treatment facilities were considered to be located at the Idaho National Engineering Laboratory, Hanford, Savannah River Plant, and Mound Laboratory. The latter two were considered only for regional treatment alternatives.

For all alternatives, it has been assumed that shipments to the repository begin in 1997 and treatment operations (only in PTRU alternative) begin in 1990. 


\subsection{CONTACT-HANDLED DEFENSE WASTE SHIPPING COST COMPARISONS AND TRANSIT TIMES}

Fees charged by the carriers to ship any cargo (shipping costs) is a function of the cargo type (hazardous, nonhazardous, etc.), cargo weight, physical configuration, distance, and frequency or number of shipments. The total turnaround time is controlled by the distance traveled, mode of shipment (truck or rail), endpoint loading and unloading times, and route characteristics.

Both contact-handled TRU wastes (CH-TRU) and processed TRU wastes (PTRU) were considered in the development of the cost comparisons and transit times in this study. Although these waste forms are different, this difference, in itself, did not affect the unit shipping costs used. The shipping costs are indirectly affected by the waste type in that each type requires a different shipping packaging with different weights and physical configurations. The turnaround time can also be affected by differences in weight and configuration due to changes in the endpoint loading and unloading time. It was assumed, in this analysis, that turnaround time is equal to twice the one way transit time plus 2 days for loading and unloading.

Since each origin must ship to the destinations by different routes, it was necessary to develop shipping cost estimates and transit times for each origin-destination combination and shipping mode. This was done by the DOE traffic managers, under contract at Hanford, researching the current tariff manuals or contacting the appropriate carriers to establish the current costs under the assumed conditions. The shipping costs, used in this analysis for truck shipments, are based on exclusive-use distance cost rates or trucks not exceeding $35,800 \mathrm{kgs}(85,000 \mathrm{lbs})$ gross weight. Therefore, variations in shipping weights, between a given orgin-destination combination, will not change the associated shipping costs. The cost rates for rail shipments are a function of weight and the shipping costs vary accordingly.

\subsubsection{CH-TRU Waste Shipments}

Four types of shipping packagings were considered for hauling the $\mathrm{CH}-\mathrm{TRU}$ wastes: two for rail and two for truck. These are the rail ATMX and rail TRUPACT 
and the truck Super Tiger ${ }^{\circledR}$ and truck TRUPACT. Table 4.11 shows these packaging types and waste canister loading characteristics used to establish the shipping costs. The average waste canister weights are shown in Table 4.12. The shipping packagings are volume limited for these relatively low density wastes. Consequently, the maximum weight carrying capabilities are never reached when using averages.

The cargo weights used for the ATMX ranged from 17,000 kgs for 100 percent Modular Box shipments to $31,000 \mathrm{~kg}$ for $100 \mathrm{RF}$ boxes. Cargo weights for the rail TRUPACT range between $26,900 \mathrm{~kg}$ for 100 percent RF boxes and 39,000 kg for 100 percent Modular Boxes and drums. Weighted averages were used for those origins with mixed waste canister combinations.

TABLE 4.11. Number of Waste Canisters per Shipping Packaging

\begin{tabular}{|c|c|c|c|c|}
\hline \multirow[b]{2}{*}{ Waste Canister } & \multicolumn{2}{|r|}{ Truck } & \multicolumn{2}{|c|}{ Rai1 } \\
\hline & TRUPACT & Super Tiger ${ }^{\circledR}$ & TRUPACT & ATMX \\
\hline Modulary Box & 6 & 2 & 8 & 16 \\
\hline RF Box & 2 & 2 & 2 & 24 \\
\hline Drums & 36 & 42 & 48 & 140 \\
\hline
\end{tabular}

TABLE 4.12. Average Waste Canister Weights

\begin{tabular}{lrr}
\multicolumn{1}{c}{ Type } & \multicolumn{2}{c}{ Weight } \\
Modular Box & 1065 & Tbs \\
RF Box & 1280 & 2350 \\
Drums $^{(a)}$ & 150 & 330
\end{tabular}

(a) Looseweight. Additional weight must be allowed for when confined by packs, frames or dunnage.

For the purposes of this analysis one trailer per truck and one shipping package per trailer were used for truck shipments of $\mathrm{CH}$-TRU wastes. For trains, two and three shipping packages per car were used for $\mathrm{CH}$-TRU wastes. 
PTRU shipments, employing reusable Type B packagings (Table 4.9), had four packages for truck and twelve containers per railcar for train.

The shipping cost estimates and transit times used for transporting the $\mathrm{CH}-\mathrm{TRU}$ waste to the Southwest repository site are listed in Table 4.13. These costs are on a per shipment basis and reflect the fuel surcharges in effect in March 1980. Tables 4.14 and 4.15 show the shipping costs and times for shipping $\mathrm{CH}-$ TRU wastes to the potential processing sites of Idaho and Hanford. The transit times shown in Tables $4.13,4.14$ and 4.15 are approximations supplied by the DOE traffic managers at Hanford. The truck times are based on a $800-$ kilometer, 10-hour day.

The large volumes of wastes expected to be shipped from a few of the origins could possibly reduce these cost estimates. It is estimated that a train load rate (20-35 cars) could be established from Hanford to the Southwest repository. This would lower the TRUPACT rate from $\$ 13,515$ to $\$ 10,800$ per car and the ATMX rate from $\$ 5,994$ to $\$ 5,088$ per car. From Idaho Falls, the rates for TRUPACTS shipped by rail could be reduced from $\$ 11,255$ to $\$ 9,000$ per car. Also, on the basis of two or more truck loads per day, the Super Tiger or TRUPACT charges from Hanford could be reduced from $\$ 3,716$ to approximately $\$ 2,900$ per truck load and the charges from Idaho Falls from $\$ 2,680$ to approximately $\$ 2,100$. Additional origins, where two or more truck loads per day may be possible are Savannah River, Los Alamos, and Rocky Flats. This would result in reduced rates of $\$ 2,700, \$ 800$, and $\$ 1,100$ per trip respectively.

The shipping costs and transit times used for the regional and alternate Western repository analysis are based on extrapolations of the Southwestern repository data. Only the TRUPACT packaging was considered for these cases.

For the rail shipping costs and the rail and truck transit times, the data used for the Southwest repository were plotted as a function of distance (Figures $4.3,4.4$ and 4.5 ). It must be noted that the rail costs are not a function of distance alone. These costs are competitive between two points served by more than one carrier. However, for the purpose of extrapolation, distance is a common factor that could be used. This technique does not give exact shipping costs, but it will provide relative costs between each origindestination combination. The truck shipping costs, Table 4.16, are actual per 
TABLE 4.13. Contact-Handled Defense Waste Shipping Costs and Transit Times to the Southwest Repository

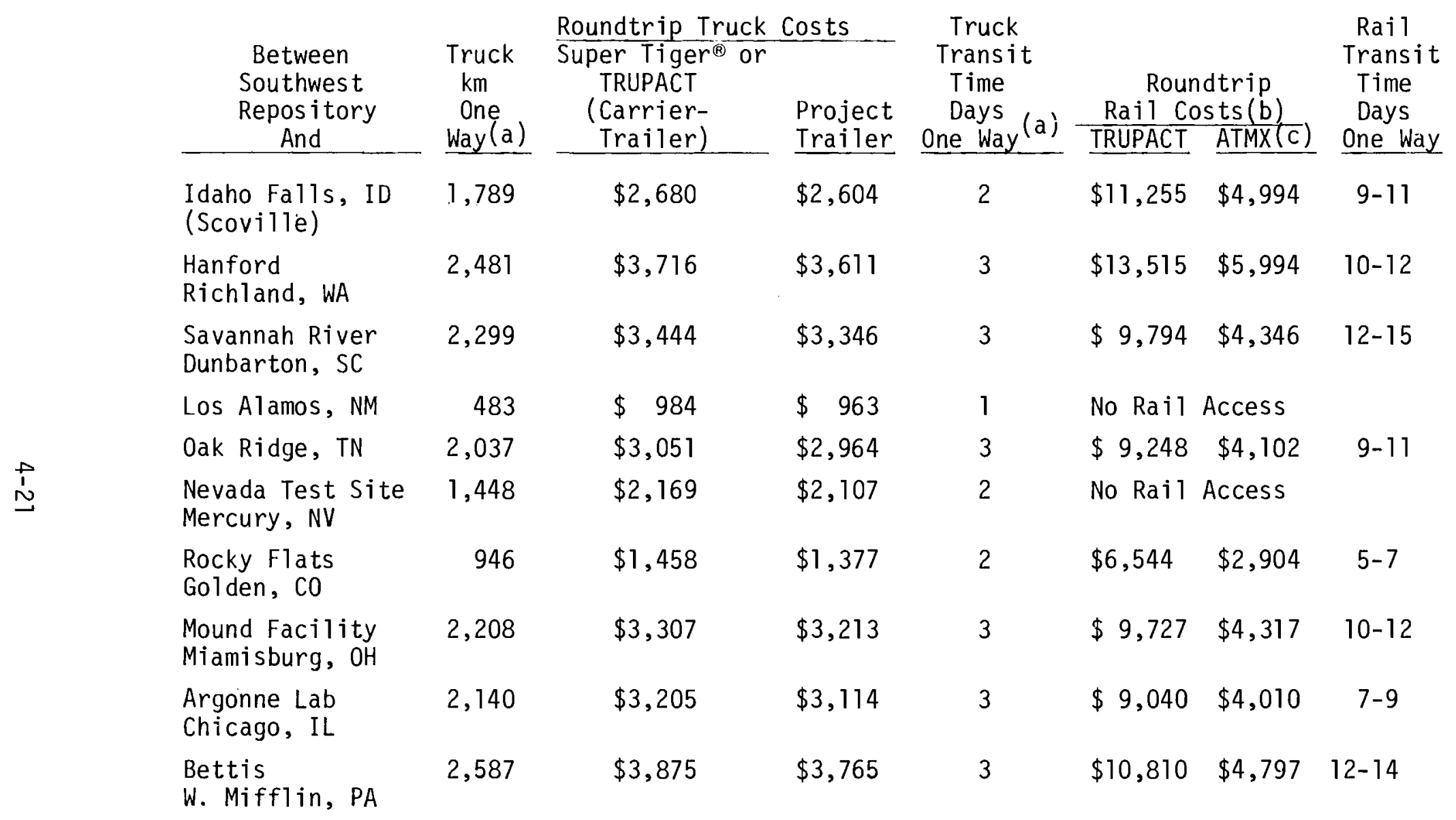

(a) 1 kilometer $=0.6214$ miles.

(b) Based on weight average canister mix.

(c) The ATMX is a unitized rail car with a classification similar to a hopper or tank car. There is no charge for its return empty. 
TABLE 4.14. Contact-Handled Defense Waste Shipping Costs and Transit Times to Idaho Falls, Idaho

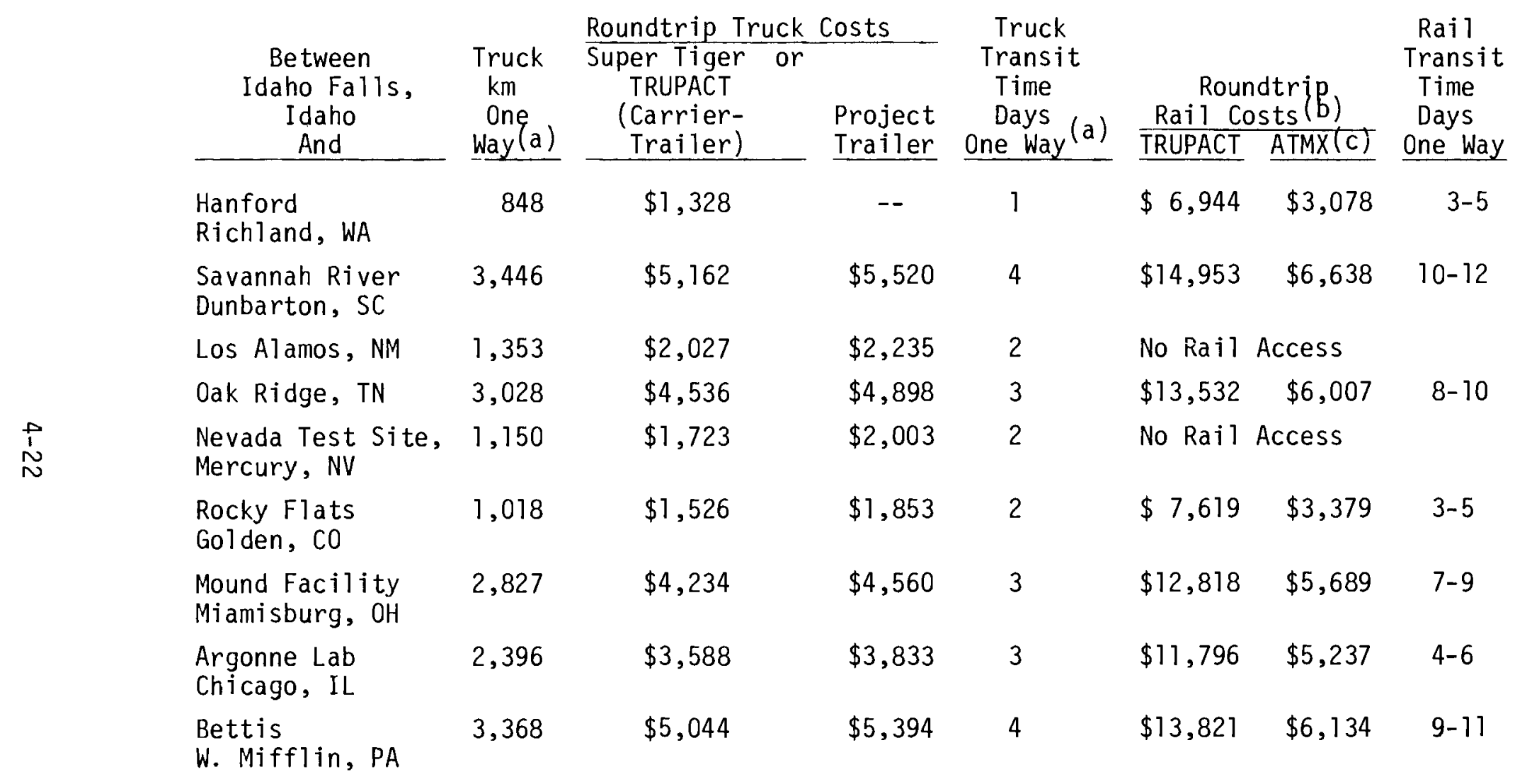

(a) 1 kilometer $=0.6214$ miles.

(b) Based on weighted average canister mix.

(c) The ATMX is a unitized rail car with a classification similar to a hopper or tank car. There is no charge for its return empty. 
TABLE 4.15. Contact-Handled Defense Waste Shipping Costs and Transit Times to Hanford, Washington

\begin{tabular}{|c|c|c|c|c|c|c|c|}
\hline $\begin{array}{c}\text { Between } \\
\text { Hanford, } \\
\text { Washington } \\
\text { And } \\
\end{array}$ & $\begin{array}{c}\text { Truck } \\
\text { km } \\
\text { One } \\
\text { Way (a) } \\
\end{array}$ & $\begin{array}{c}\text { Roundtrip Truck } \\
\text { Super Tiger or } \\
\text { TRUPACT } \\
\text { (Carrier- } \\
\text { Trailer) } \\
\end{array}$ & $\begin{array}{l}\text { Project } \\
\text { Trailer } \\
\end{array}$ & $\begin{array}{l}\text { Truck } \\
\text { Transit } \\
\text { Time } \\
\text { Days (a) } \\
\text { One Way } \\
\end{array}$ & $\begin{array}{r}\text { Rour } \\
\text { Rail Cc } \\
\text { TRUPACT } \\
\end{array}$ & $\begin{array}{l}\text { dtrib } \\
\text { sts }(B) \\
\text { ATMX(c) }\end{array}$ & $\begin{array}{l}\text { Rail } \\
\text { Transit } \\
\text { Time } \\
\text { Days } \\
\text { One Way } \\
\end{array}$ \\
\hline $\begin{array}{l}\text { Idaho Falls, ID } \\
\text { (Scoville) }\end{array}$ & 848 & $\$ 1,328$ & - & 1 & $\$ 6,944$ & $\$ 3,065$ & $3-5$ \\
\hline $\begin{array}{l}\text { Savannah River, } \\
\text { Dunbarton, SC }\end{array}$ & 4,290 & $\$ 6,425$ & $\$ 6,939$ & 5 & $\$ 16,028$ & $\$ 7,083$ & $12-14$ \\
\hline Los Alamos, Nil & 1,977 & $\$ 2,962$ & $\$ 3,204$ & 3 & No Rail & Access & \\
\hline Oak Ridge, TN & 3,825 & $\$ 5,729$ & $\$ 6,175$ & 4 & $\$ 14,727$ & $\$ 6,506$ & $10-12$ \\
\hline $\begin{array}{l}\text { Nevada Test Site, } \\
\text { Mercury, NV }\end{array}$ & 1,638 & $\$ 2,453$ & $\$ 2,616$ & 2 & No Rail & Access & \\
\hline $\begin{array}{l}\text { Rocky Flats, } \\
\text { Golden Co }\end{array}$ & 1,802 & $\$ 2,699$ & $\$ 2,893$ & 2 & $\$ 10,420$ & $\$ 4,604$ & $4-6$ \\
\hline $\begin{array}{l}\text { Mound Facility } \\
\text { Miamisburg, OH }\end{array}$ & 3,495 & $\$ 5,235$ & $\$ 5,592$ & 4 & $\$ 14,208$ & $\$ 6,275$ & $8-10$ \\
\hline $\begin{array}{l}\text { Argonne Lab } \\
\text { Chicago, IL }\end{array}$ & 3,039 & $\$ 4,552$ & $\$ 4,899$ & 3 & $\$ 13,515$ & $\$ 5,970$ & $5-7$ \\
\hline $\begin{array}{l}\text { Bettis, } \\
\text { W. Mifflin, PA }\end{array}$ & 4,006 & $\$ 6,001$ & $\$ 6,418$ & 4 & $\$ 14,909$ & $\$ 6,587$ & $10-12$ \\
\hline
\end{tabular}

(a) 1 kilometer $=0.6214$ miles.

(b) Based on weighted average canister mix.

(c) The ATMX is a unitized rail car with a classification similar to a hopper or tank car. There is no charge for its return empty. 


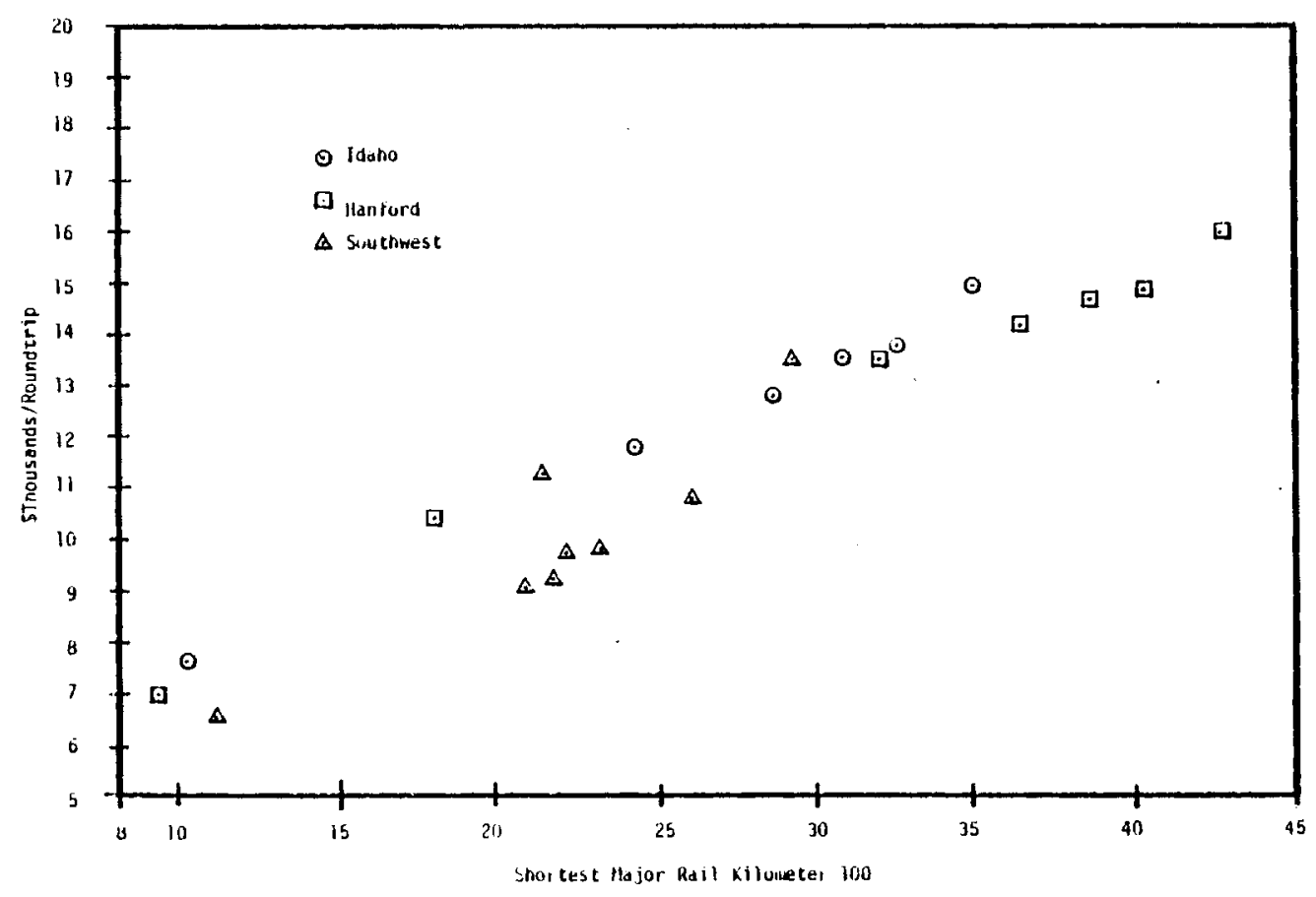

FIGURE 4.3. Rail Shipping Costs for $\mathrm{CH}$-TRU Wastes

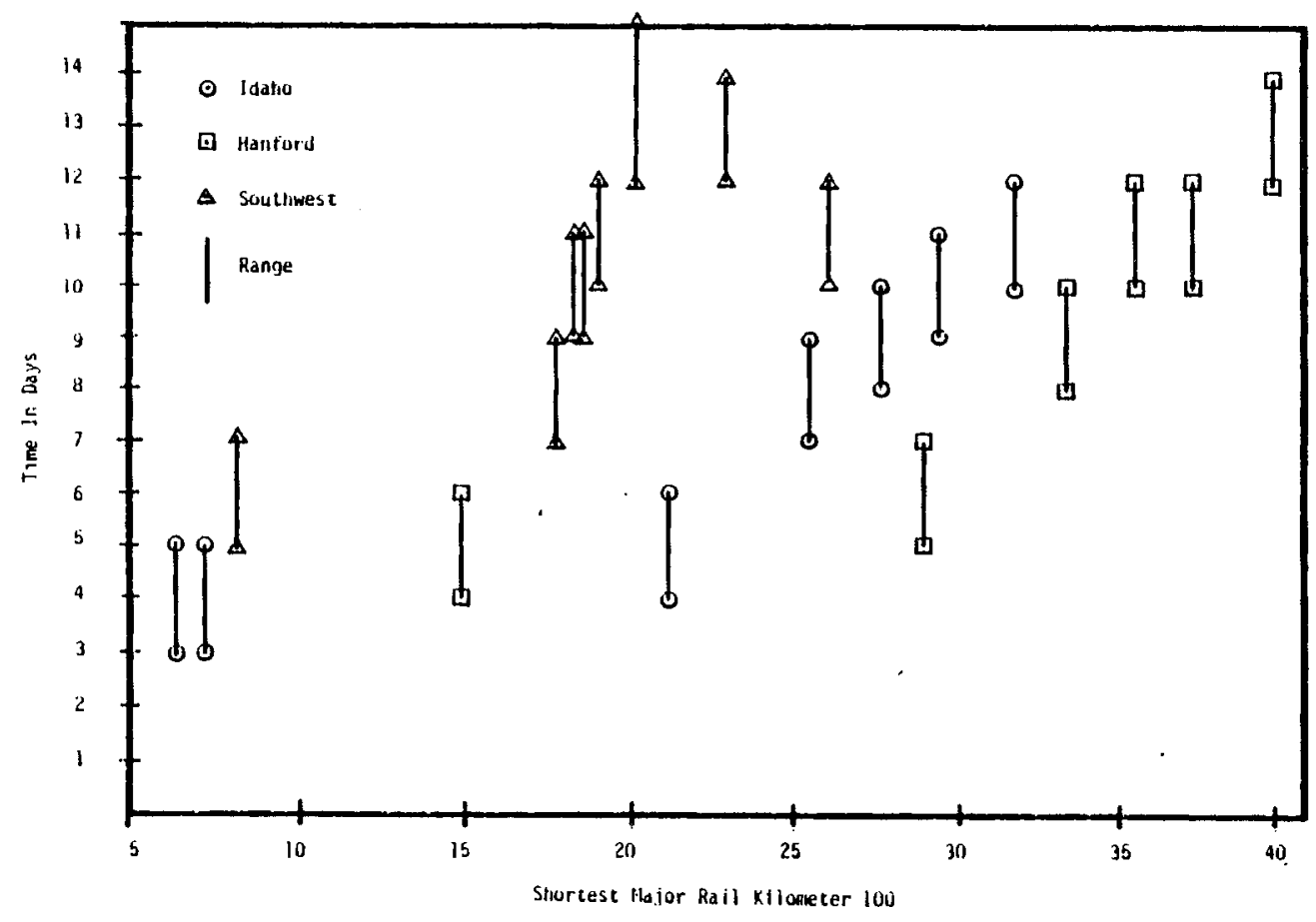

FIGURE 4.4. Rail Transit Time for CH-TRU Wastes 


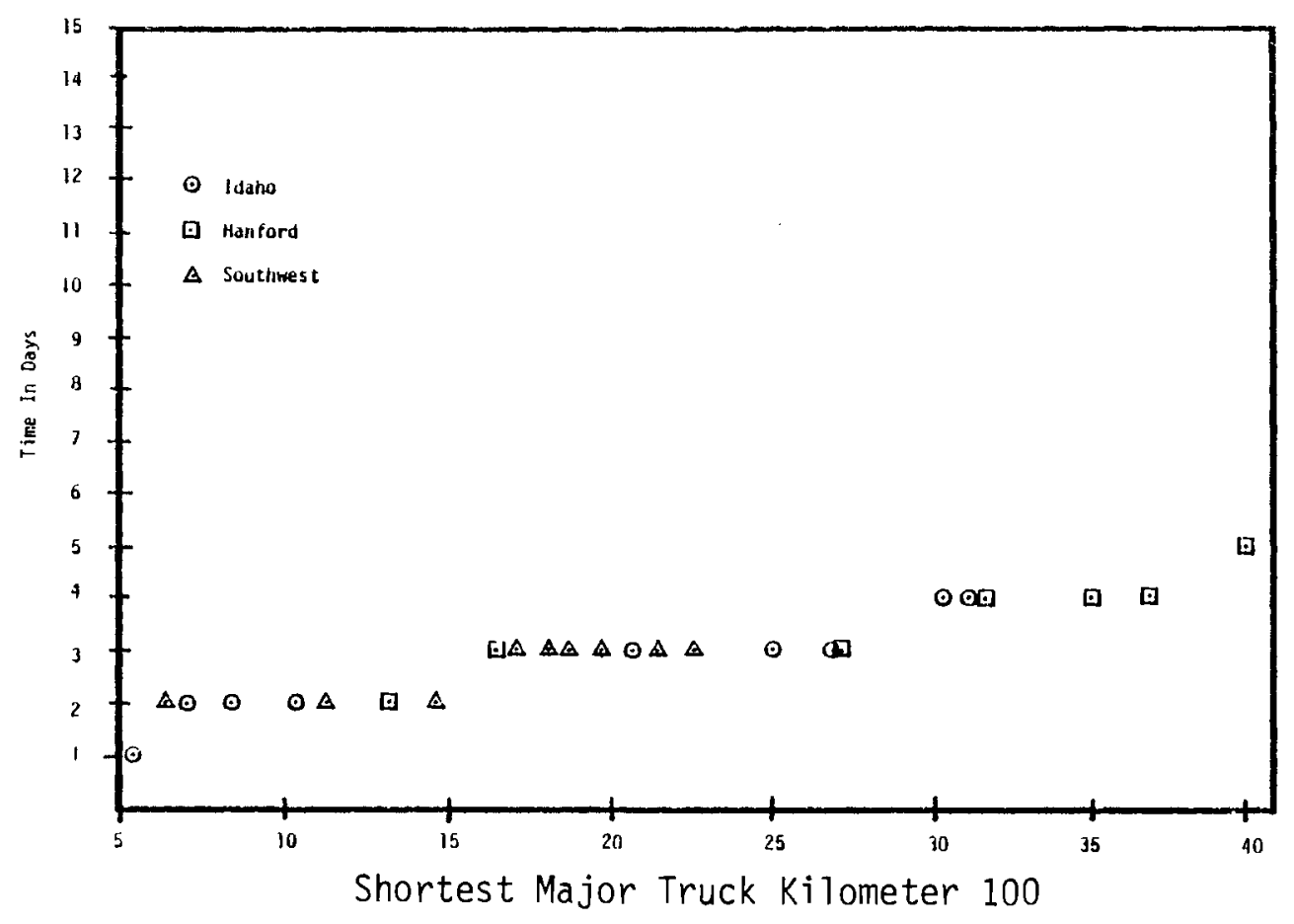

FIGURE 4.5. Truck Transit Time for CH-TRU Wastes

TABLE 4.16. Truck Shipping Cost Rates (a)

\begin{tabular}{|c|c|c|c|c|c|}
\hline & \multicolumn{2}{|c|}{ Round Trip Cost } & \multirow{2}{*}{$\begin{array}{l}\text { One Way } \\
\$ / \text { mile }\end{array}$} & \multirow{2}{*}{$\begin{array}{l}\text { Cost } \\
\$ / \mathrm{km} \\
\end{array}$} \\
\hline (</miles) & $(\mathrm{km})$ & $\$ / \mathrm{mi} 7 \mathrm{e}$ & $\$ / \mathrm{km}$ & & \\
\hline 100 & 161 & 3.69 & 3.53 & 2.34 & 1.77 \\
\hline 150 & 241 & 4.90 & 3.05 & 2.45 & 7.52 \\
\hline 200 & 322 & 4.13 & 2.57 & 2.05 & 1.28 \\
\hline 250 & 402 & 3.74 & 2.32 & 1.87 & 1.16 \\
\hline 300 & 4.33 & 3.28 & 2.04 & 1.64 & 1.92 \\
\hline 350 & 563 & 3.06 & 1.90 & 1.53 & 0.95 \\
\hline 400 & 644 & 2.79 & 1.73 & 1.39 & 0.86 \\
\hline 450 & 724 & 2.66 & 1.65 & 1.33 & 0.83 \\
\hline 500 & 805 & 2.54 & 1.58 & 1.27 & 0.79 \\
\hline 550 & 885 & 2.52 & 1.57 & 1.26 & 0.78 \\
\hline 600 & 965 & 2.48 & 1.54 & 1.24 & 0.77 \\
\hline+601 & +967 & 2.41 & 1.50 & 1.20 & 0.75 \\
\hline
\end{tabular}

(a) Includes $11.5 \%$ Fuel Surtax.

(b) 1 mile $=1.609$ kilometer; 1 kilometer $=$

0.6214 miles

$$
4-25
$$


distance costs for an exclusive-use trailer in effect as of March 1980. These costs are not a function of weight and are based strictly on distance.

Distance between the waste source and the repository destinations shown in Table 4.17 were obtained from the National Atlas (USGS 1970) and the USGS Rail Maps (1975). These distances were then used with an extrapolation of the rail transit time, rail shipping costs, truck transit time, and truck shipping costs (Table 4.16) to provide the resultant costs and times shown in Table 4.18 and 4.19 .

\subsubsection{PTRU Waste Shipments}

Four shipping packaging categories were considered in the development of the PTRU shipping rates (see Section 3 ). These were a Type $B$ disposable, a Type B non-disposable, a Low-Level Solid disposable and TRUPACTs. Although the volumes differ, the loaded shipping weights shown in Table 4.20 are the same for all four rail systems. Changes in truck weights (exclusive-use) do not affect the shipping costs. The purchase of disposable packagings was assumed not to be a part of the waste transportation costs. Consequently, when shipping these packagings, the only cost considered is a one-way shipping charge. The costs for shipping PTRU wastes to the Southwest repository are in Table 4.21. Costs for PTRU waste shipments in TRUPACT packagings are similar to those for CH-TRU.

PTRU wastes rail shipping costs and transit times for the regional and alternate Western repository analysis, like the $\mathrm{CH}$-TRU wastes, were developed from extrapolations of the Southwest repository data (Figure 4.6). Truck shipping costs are based on the truck charges in Table 4.16 and the mileage from Table 4.17. The resulting costs and times are shown in Table 4.22 for disposable packages and in Table 4.23 for reusable packagings.

\subsection{RESULTS OF CONTACT-HANDLED DEFENSE WASTE TRANSPORTATION COST AND LOGISTICS ANALYSES}

Results of this transportation cost and logistics study include information on total defense waste transportation costs, levelized costs per unit of waste 
TABLE 4.17. One-Way Distances ${ }^{(a)}$ to Regional and Alternate Western Repository Sites

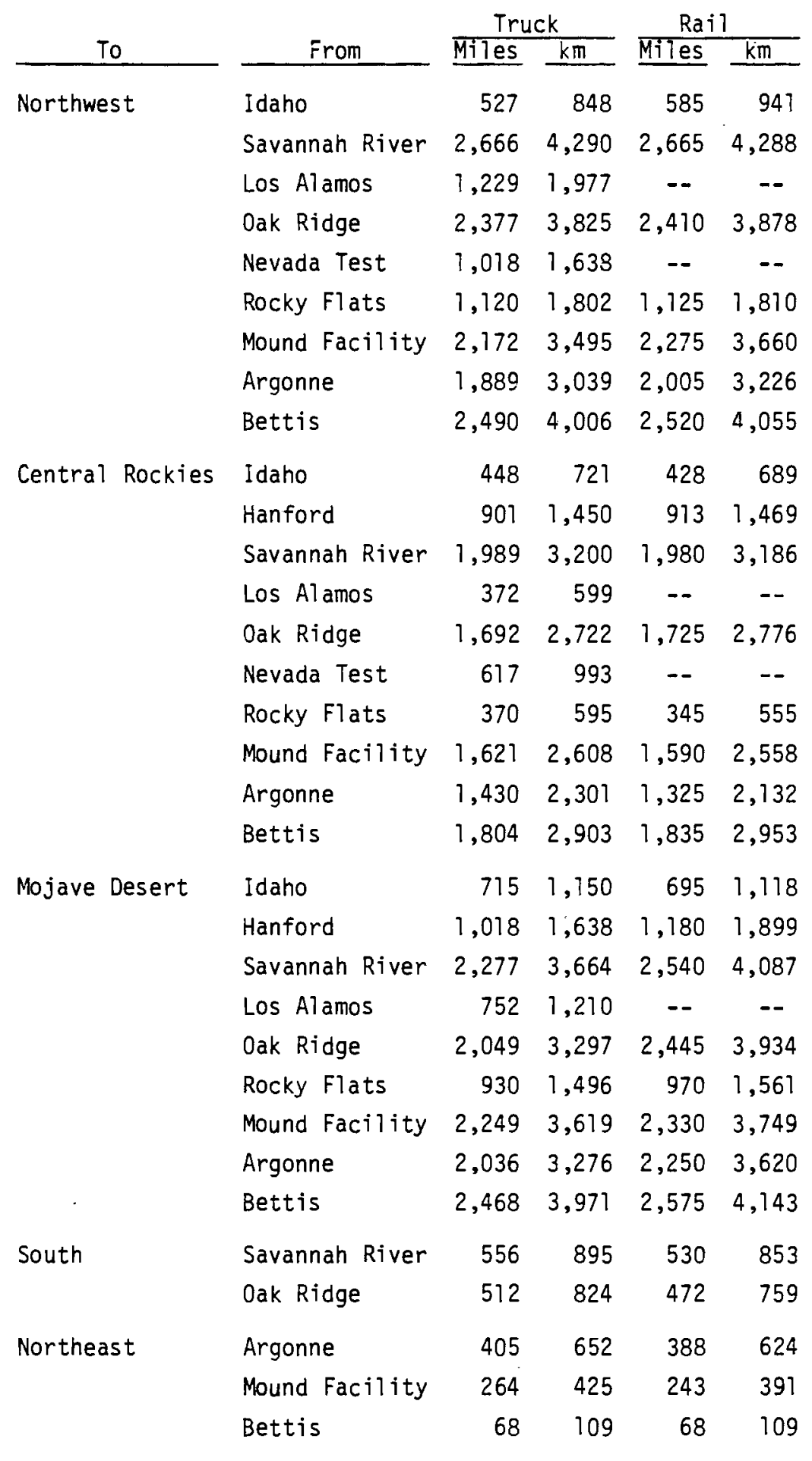

(a) 1 mile $=1.609$ kilometer, 1 kilometer $=0.6214$ miles. 
TABLE 4.18. CH-TRU Shipping Costs to Regional and Alternate Western Repository Sites, \$/Roundtrip

\begin{tabular}{|c|c|c|c|}
\hline To & From & Truck & Rail \\
\hline \multirow[t]{9}{*}{ Northwest } & Idaho & 1,328 & 6,944 \\
\hline & Savannah River & 6,425 & 16,028 \\
\hline & Los Alamos. & 2,962 & -- \\
\hline & Oak Ridge & 5,729 & 14,727 \\
\hline & Nevada Test & 2,453 & -- \\
\hline & Rocky Flats & 2,699 & 10,420 \\
\hline & Mound Facility & 5235 & 14,208 \\
\hline & Argonne & 4,552 & 13,515 \\
\hline & Bettis & 6,001 & 14,909 \\
\hline \multirow[t]{10}{*}{ Central Rockies } & Idaho & 1,192 & 5,164 \\
\hline & Hanford & 2,171 & 7,691 \\
\hline & Savannah River & 4,793 & 13,251 \\
\hline & Los Alamos & 1,038 & -- \\
\hline & Oak Ridge & 4,078 & 11,922 \\
\hline & Nevada Test & 1,487 & - \\
\hline & Rocky Flats & 1,032 & 4,731 \\
\hline & Mound Facility & 3,907 & 11,219 \\
\hline & Argonne & 3,446 & 9,838 \\
\hline & Bettis & 4,348 & 12,495 \\
\hline \multirow[t]{9}{*}{ Mojave Desert } & Idaho & 1,723 & 6,555 \\
\hline & Hanford & 2,453 & 9,082 \\
\hline & Savannah River & 5,488 & 16,169 \\
\hline & Los Alamos & 1,812 & - \\
\hline & Oak Ridge & 4,938 & 15,674 \\
\hline & Rocky Fiats & 2,241 & 7,988 \\
\hline & Mound Facility & 5,420 & 15,075 \\
\hline & Argonne & 4,907 & 14,658 \\
\hline & Bettis & 5,948 & 16,351 \\
\hline \multirow[t]{2}{*}{ South } & Savannah River & 1,379 & 5,695 \\
\hline & Oak Ridge & 1,290 & 5,393 \\
\hline \multirow[t]{3}{*}{ Northeast } & Argonne & 1,077 & 4,255 \\
\hline & Mound Facility & 866 & 4,200 \\
\hline & Bettis & 387 & 3,288 \\
\hline
\end{tabular}

TABLE 4.19. One-Way Transit Times to Regional and Alternate Western Repository Sites, Days

\begin{tabular}{|c|c|c|c|}
\hline To & From & Truck & Rail \\
\hline \multirow{9}{*}{ Northwest } & I daho & 1.1 & 4.8 \\
\hline & Savannah River & 5.3 & 10.8 \\
\hline & Los Alamos & 2.5 & -- \\
\hline & Oak Ridge & 4.8 & 10.3 \\
\hline & Nevada Test & 2.0 & -- \\
\hline & Rocky Flatis & 2.2 & 7.8 \\
\hline & Mound Facility & 4.3 & 10.0 \\
\hline & Argonne & 3.8 & 9.5 \\
\hline & Bettis & 5.0 & 10.5 \\
\hline \multirow[t]{10}{*}{ Central Rockies } & Idaho & .9 & 3.6 \\
\hline & Hanford & 1.8 & 6.8 \\
\hline & Savannah River & 4.0 & 9.5 \\
\hline & Los Alamos & .7 & -- \\
\hline & Oak Ridge & 3.4 & 6.0 \\
\hline & Nevada Test & 1.2 & -- \\
\hline & Rocky Flats & .7 & 3.0 \\
\hline & Mound racility & 3.2 & 9.2 \\
\hline & Argonne & 2.9 & 8.6 \\
\hline & Bettis & 3.6 & 9.3 \\
\hline \multirow[t]{9}{*}{ Mojave Desert } & Idaho & 1.4 & 5.5 \\
\hline & Hanford & 2.0 & 8.1 \\
\hline & Savannah River & 4.6 & 10.5 \\
\hline & Los Alamos & 1.5 & - \\
\hline & Oak Ridge & 4.1 & 10.3 \\
\hline & Rocky Flats & 1.9 & 7.1 \\
\hline & Mound Facility & 4.5 & 10.1 \\
\hline & Argonne & 4.1 & 10.0 \\
\hline & Bettis & 4.9 & 10.6 \\
\hline \multirow[t]{2}{*}{ Scuth } & Savannah River & 1.1 & 4.4 \\
\hline & Oak Ridge & 1.0 & 4.0 \\
\hline \multirow[t]{3}{*}{ Northeast } & Argonne & .8 & 3.3 \\
\hline & Mound Facility & .5 & 2.2 \\
\hline & Bettis & .1 & .6 \\
\hline
\end{tabular}


TABLE 4.20. PTRU Shipping Packaging Types and Weights

\begin{tabular}{|c|c|c|c|c|}
\hline \multirow{2}{*}{ Mode } & \multicolumn{3}{|c|}{ Weights, Ki lograms (a) } & \multirow{2}{*}{ Packaging Type } \\
\hline & Empty & Cargo & Fu11(b) & \\
\hline Rail & 27,200 & 32,700 & 60,000 & Type B Reusable \\
\hline Rail & 0 & 59,900 & 60,000 & $\begin{array}{l}\text { Type B Disposable or Low- } \\
\text { Level Solid Disposable }\end{array}$ \\
\hline Truck & 9,100 & 10,900 & 20,000 & Type B Reusable \\
\hline Truck & 0 & 20,000 & 20,000 & $\begin{array}{l}\text { Type B Disposable or Low- } \\
\text { Level Solid Disposable }\end{array}$ \\
\hline Rail & 21,800 & 38,100 & 60,000 & TRUPACT \\
\hline Truck & 10,000 & 12,700 & 22,700 & TRUPACT \\
\hline
\end{tabular}

(a) 1 kilogram $=2.205$ pounds.

(b) Numbers are rounded.

TABLE 4.21. Shipping Costs for PTRU Rates to the Southwestern Repository Using Disposable Type B Packagings

\begin{tabular}{|c|c|c|c|c|}
\hline \multirow{2}{*}{\multicolumn{5}{|c|}{ 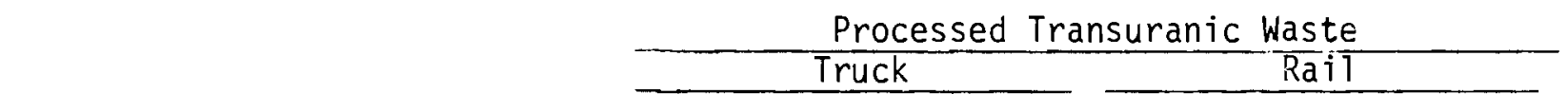 }} \\
\hline & & & & \\
\hline & $\begin{array}{l}\text { One-Way } \\
\text { Loaded Cost }\end{array}$ & $\begin{array}{l}\text { Roundtrip } \\
\text { Cost }\end{array}$ & $\begin{array}{l}\text { One Way } \\
\text { Loaded Cost }\end{array}$ & $\begin{array}{l}\text { Roundtrip } \\
\text { Cost } \\
\end{array}$ \\
\hline \multicolumn{5}{|c|}{$\begin{array}{l}\text { Between Southwest Repository } \\
\text { Site and: }\end{array}$} \\
\hline Idaho Falls, ID & $\$ 1,340$ & $\$ 2,680$ & $\$ 11,517$ & $\begin{array}{l}\$ 16,424 \\
(15,443)\end{array}(a)$ \\
\hline Hanford/Richland, WA & 1,858 & 3,716 & 13,825 & $\begin{array}{c}19,721 \\
(18,542)\end{array}(a)$ \\
\hline \multicolumn{5}{|c|}{$\begin{array}{l}\text { Between Northwest Repository } \\
\text { Site and: }\end{array}$} \\
\hline Idaho Falls, ID & 664 & 1,328 & 7,099 & 10,132 \\
\hline
\end{tabular}




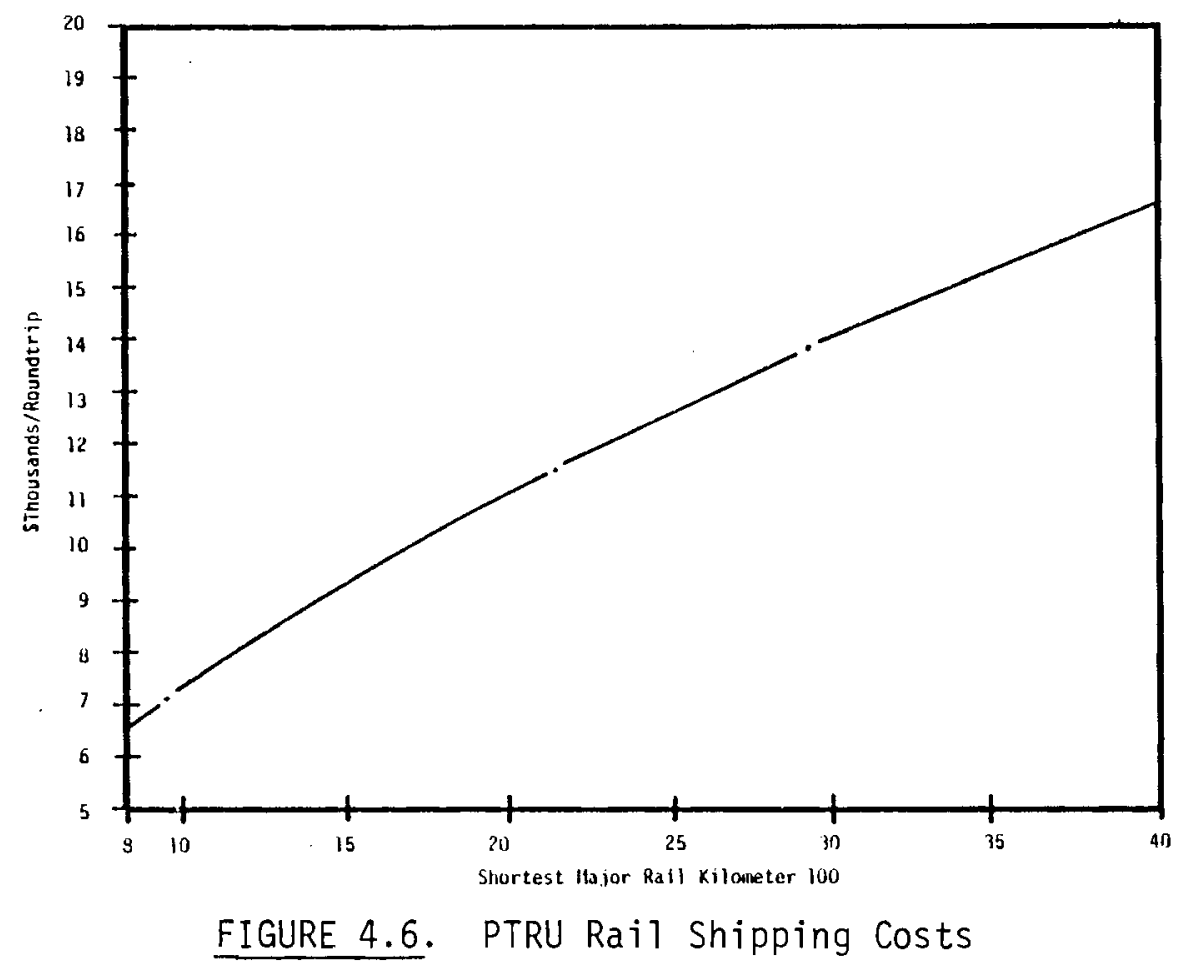

TABLE 4.22. Shipping Costs and Transit Times for PTRU Disposable Packages to the Regional and Alternate Western Repository

\begin{tabular}{|c|c|c|c|c|c|}
\hline To & From & $\begin{array}{l}\$ / \text { Trip } \\
\text { Truck }\end{array}$ & $\begin{array}{c}\text { One-Way } \\
\text { Truck Transit } \\
\text { Time, Days } \\
\end{array}$ & $\begin{array}{l}\text { \$/Trip } \\
\text { Rail } \\
\end{array}$ & $\begin{array}{l}\text { One-llay } \\
\text { Rail Trans it } \\
\text { Time, Days }\end{array}$ \\
\hline \multirow[t]{2}{*}{ Central Rockies } & Idaho & 596 & .9 & 5,910 & 3.6 \\
\hline & Hanford & 1,086 & 1.8 & 9,208 & 6.8 \\
\hline \multirow[t]{2}{*}{ Mojave Desert } & Idaho & 862 & 1.4 & 7,849 & 5.5 \\
\hline & Hanford & 1,227 & 2.0 & 10,700 & 8.1 \\
\hline \multirow[t]{2}{*}{ South } & Savannah River & 689 & 1.1 & 6,698 & 4.4 \\
\hline & Oak Ridge & 645 & 1.0 & 6,258 & 4.0 \\
\hline \multirow[t]{3}{*}{ Northeast } & Argonne & 539 & .8 & 5,580 & 3.3 \\
\hline & Mound Laboratory & 433 & .5 & 4,243 & 2.2 \\
\hline & Bettis & 193 & .1 & 2,013 & .6 \\
\hline
\end{tabular}


TABLE 4.23. Shipping Costs and Transit Times for PTRU Non-Disposable Packagings to the Regional and Alternate Repository

\begin{tabular}{|c|c|c|c|c|c|}
\hline To & From & $\begin{array}{l}\text { \$/Trip } \\
\text { Iruck }\end{array}$ & \begin{tabular}{c}
\multicolumn{2}{c}{ One-Way } \\
Truck Transit \\
Time, Days \\
\end{tabular} & $\begin{array}{c}\text { \$/Trip } \\
\text { Rail }\end{array}$ & $\begin{array}{l}\text { One-Way } \\
\text { Rail Transit } \\
\text { Time, Days } \\
\end{array}$ \\
\hline \multirow[t]{2}{*}{ Central Rockies } & Idaho & 1,192 & .9 & $8,4.35$ & 3.6 \\
\hline & Hanford & 2,171 & 1.8 & 13,142 & 6.8 \\
\hline \multirow[t]{2}{*}{ Mojave Desert } & Idaho & 1,723 & 1.4 & 11,197 & 5.5 \\
\hline & Hanford & 2,453 & 2.0 & 15,264 & 8.1 \\
\hline \multirow[t]{2}{*}{ South } & Savannah River & 1,379 & 1.1 & 9,560 & 4.4 \\
\hline & Oak Ridge & 1,290 & 1.0 & 8,932 & 4.0 \\
\hline \multirow[t]{3}{*}{ Northeast } & Argonne & 1,077 & .8 & 7,964 & 3.3 \\
\hline & Mound Facility & 866 & .5 & 6,056 & 2.2 \\
\hline & Bettis & 387 & .1 & 2,873 & .6 \\
\hline
\end{tabular}

volume disposed, annual number of shipments by transport mode, transport packaging requirements, and required facility volume throughputs for the alternatives described in Section 4.3. Only costs related to transporting the wastes are included. Treatment, packaging, exhumation, and disposal costs, which may be larger than the transportation costs, are not included. Transportation costs include purchase and maintenance of transport packagings and fees paid to carriers for transporting the material. Cost computations are all done in constant 1980 dollars. The levelized unit costs are in dollars per cubic meter of untreated waste emplaced, for both the no treatment and the treatment alternatives.

The results of the analysis of transportation requirements to transport contact-handled defense wastes are presented in the following sequence. First the transportation requirements for transporting surface stored waste and future generated waste to a single national repository located in the southwest is presented in Section 4.5.1. This represents the reference case. 
Effects on the reference case of alternate buried waste retrieval policies are presented in Section 4.5.2. The effects on transportation system requirements from implementing a treatment before disposal policy are discussed in Section 4.5.3. The effects of alternative CH-TRU transportation system hardware are presented in Section 4.5.4. Transportation system impacts of a regional waste repository policy are presented in Section 4.5.5. Facility location effects are discussed in Section 4.5.6. Last, the sensitivity of the contact handled defense waste transportation requirements to changes in basic assumptions used in this analysis are presented in Section 4.5.7.

\subsubsection{CH-TRU Waste Transportation Reference Case}

With a repository receiving rate of $10,000 \mathrm{~m}^{3} /$ year, it will require just over twenty years to dispose of projected future waste generation and to eliminate surface-stored waste backlogs. This result assumes a single repository beginning operation in 1997 and that the $\mathrm{CH}$-TRU wastes are shipped in their present form, with no volume change due to treatment or repackaging. Assuming the use of both rail and truck-sized TRUPACT packagings, $75 \%$ of the waste volume in rail shipments, and a repository located in the southwest, the following transportation characteristics result. About 480 truck shipments and 320 rail shipments will be received at the repository each year. Fifty rail TRUPACTS and eleven truck-sized TRUPACTs are required, costing $\$ 12.3$ million. Shipping and maintenance costs are estimated to be $\$ 97 \mathrm{million}$ over the twenty-year period. The levelized unit cost is $\$ 552 / \mathrm{m}^{3}$ at $0 \%$ discount rate and $\$ 633 / \mathrm{m}^{3}$ at $10 \%$ discount rate.

Plans for the Waste Isolation Pilot Plant (WIPP) indicate a maximum waste receiving rate of $34,000 \mathrm{~m}^{3} /$ year. At this rate, the surface-stored backlog is eliminated in about four years. Four times as many shipping packagings would be required compared to the $10,000 \mathrm{~m}^{3} /$ year case. Levelized unit costs increase because most of the TRUPACT packagings are not well-utilized after the first four years of repository operation. These effects are shown in Table 4.24. If additional wastes are transported using the idle containers, unit costs would return to those of the base case. 
TABLE 4.24. Effects of Accelerated Emplacement

\begin{tabular}{|c|c|c|c|}
\hline & $\begin{array}{c}\text { Base Case } \\
20 \text { Year } \\
\text { Backlog } \\
\end{array}$ & $\begin{array}{c}\text { Accelerated } \\
4 \text { Year } \\
\text { Backlog } \\
\end{array}$ & $\begin{array}{l}\text { Percent } \\
\text { Change }\end{array}$ \\
\hline Emplacement Rate $\mathrm{m}^{3} /$ year & 10,000 & 34,000 & +240 \\
\hline \multicolumn{4}{|l|}{ Shipments per Year } \\
\hline Rai1 & 320 & 1,230 & +284 \\
\hline Truck & 480 & 1,550 & +223 \\
\hline Total & 800 & 2,780 & +248 \\
\hline \multicolumn{4}{|l|}{ Packagings Required } \\
\hline Rail TRUPACT & 50 & 193 & +286 \\
\hline Truck TRUPACT & 11 & 35 & +218 \\
\hline Total & 61 & 228 & +274 \\
\hline \multicolumn{4}{|l|}{20 Year Cost - \$Million } \\
\hline Capital & 12.3 & 45.6 & +271 \\
\hline Shipping and Maintenance & 97.2 & 98.5 & +1 \\
\hline Total & 109.5 & 144.1 & +32 \\
\hline \multicolumn{4}{|l|}{ Levelized Unit Cost $\left(\$ / \mathrm{m}^{3}\right)$} \\
\hline $0 \%$ Discount Rate & 552 & 722 & +31 \\
\hline 10\% Discount Rate & 633 & 865 & +37 \\
\hline
\end{tabular}

\subsubsection{Transportation System Effects Due to Buried CH-TRU Waste Disposal}

Table 4.25 summarizes the effect of also shipping buried wastes and contaminated soil. The addition of buried wastes requires transportation systems and repository receiving capacities over 4 times as large as the 20-year reference case. Adding the contaminated soil category requires a repository capacity 60 times greater than the reference 20-year case and transportation system 74 times as large as the reference case. Since packagings have high utili-zation in all cases, the levelized unit costs increase only 6 and 24 percent respectively. The unit cost increase stems from changing the proportion of wastes generated at various sources. 
TABLE 4.25. Effects of Emplacing Additional CH-TRU Waste Categories

\begin{tabular}{|c|c|c|c|c|c|}
\hline & $\begin{array}{l}\quad \text { Base Case } \\
\text { Future Generation } \\
\text { Plus Retrievably } \\
\text { Stored } \\
\end{array}$ & $\begin{array}{l}\text { Buried Waste } \\
\text { Added } \\
\end{array}$ & $\begin{array}{l}\text { Percent } \\
\text { Change } \\
\text { From Base } \\
\end{array}$ & $\begin{array}{c}\text { Contaminated } \\
\text { Soil and } \\
\text { Buried Waste } \\
\text { Added } \\
\end{array}$ & $\begin{array}{l}\text { Percent } \\
\text { Change } \\
\text { From Base } \\
\end{array}$ \\
\hline Emplacement Rate $\mathrm{m}^{3} /$ year & 10,000 & 45,000 & +350 & 600,000 & $+6,000$ \\
\hline Backlog Elimination (years) & 20 & 22 & +10 & 25 & +25 \\
\hline \multicolumn{6}{|l|}{ Shipments per Year } \\
\hline Rail & 320 & 1,570 & +390 & 22,200 & $+6,840$ \\
\hline Truck & 480 & 1,790 & +273 & 20,100 & $+4,090$ \\
\hline Total & 800 & 3,360 & +320 & 42,300 & $+5,190$ \\
\hline \multicolumn{6}{|l|}{ Packagings Required } \\
\hline Rail TRUPACT & 50 & 231 & +400 & 3,755 & $+7,400$ \\
\hline Truck TRUPACT & 11 & 47 & +327 & 649 & $+5,800$ \\
\hline Total & 61 & 298 & 389 & 4,404 & $+7,120$ \\
\hline \multicolumn{6}{|l|}{ 20-Year Cost - \$Million } \\
\hline Capital & 12.3 & 59.4 & +383 & 880 & $+7,050$ \\
\hline Shipping and Maintenance & 97.2 & 466.9 & +380 & 7,350 & $+7,460$ \\
\hline Total & 109.5 & 526.3 & +381 & 8,230 & $+7,420$ \\
\hline \multicolumn{6}{|l|}{ Levelized Unit Cost $\left(\$ / \mathrm{m}^{3}\right)$} \\
\hline $0 \%$ Discount Rate & 552 & 585 & +6 & 686 & +24 \\
\hline $10 \%$ Discount Rate & 633 & 674 & +6 & 785 & +24 \\
\hline
\end{tabular}

\subsubsection{Transportation System Effects of Treating CH-TRU Wastes}

The effect of pretreating and repackaging $\mathrm{CH}-\mathrm{TRU}$ wastes on the transportation requirement is presented in Table 4.26. A single treatment facility at the INEL or two treatment facilities, one each at the INEL and Hanford were examined. For the single treatment facility, all CH-TRU wastes are shipped to the INEL for treatment, using TRUPACT's and the 75/25 percent rail/truck shares. The PTRU wastes are then shipped to the repository as Low-Level Solids. In the two treatment facility case, Hanford wastes are treated at Hanford, and the PTRU wastes are shipped directly to the repository. CH-TRU wastes from a11 sources other than Hanford are shipped to the INEL for treatment, and the PTRU wastes are then shipped to the repository. These locations of waste treatment facilities greatly reduce transportation requirements for shipping $\mathrm{CH}-\mathrm{TRU}$ wastes, but an additional shipment of PTRU wastes after treatement is required. Total transportation cost is reduced about 14\% ( $\$ 15$ miliion) with the single treatment facility and about $26 \%$ ( $\$ 29$ million) with two treatment facilities. 
TABLE 4.26. Effects of Pretreating CH-TRU Wastes

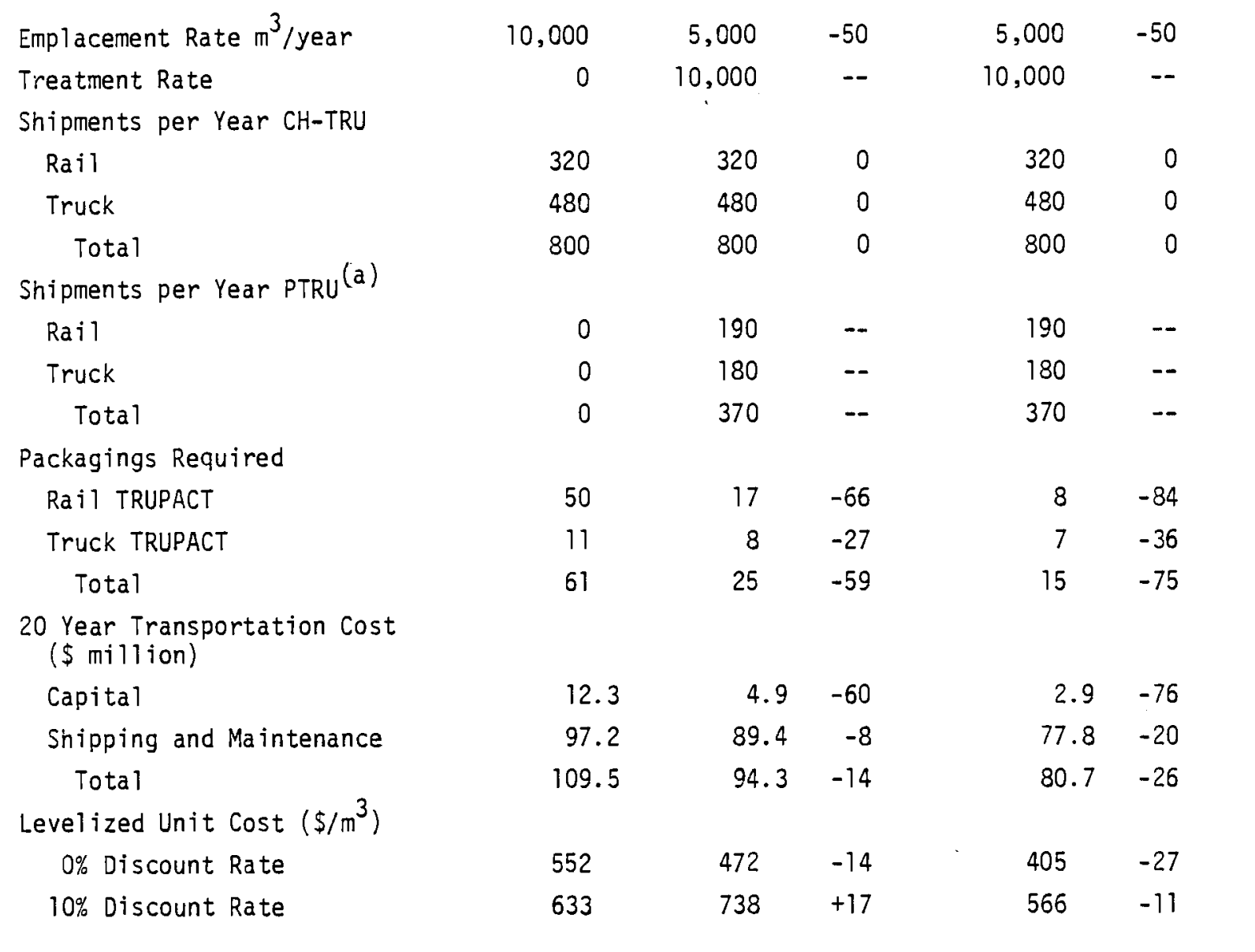

$\begin{array}{cccc}\text { Base Case } & \begin{array}{c}\text { Treatment } \\ \text { No Treatment } \\ \text { Location }\end{array} \text { From Base } & \text { Treatment Change } \\ \text { Location } & \text { From Base }\end{array}$

320

480

320

320

480

$800 \quad 0$

Total
Shipments per Year PTRU

(a) CH-TRU material treated at waste source constitute shipments but at zero cost and zero packaging requirements.

Levelized unit costs using a 10\% discount rate are distorted in this case due to timing of treatment and disposal facility operations. Treatment facilities were assumed to start up in 1990 with the repositories not starting operations until 1997.

\subsubsection{Effects of Transportation System Alternatives}

Three major types of transportation system alternatives were analyzed. The first alternative considered various levels of truck and rail transport 
mode. In the second, various hardware configurations were used for the transport of CH-TRU wastes. The last set of alternatives allows PTRU wastes to be transported in different regulatory categories.

The effects on transportation requirements for increasing truck shipping are summarized in Table 4.27. The assumed percentage shipped by truck was increased from $25 \%$ in the base case to $50 \%$ and to $100 \%$. This comparison is made on the no-treatment, single-repository scenario using TRUPACT shipping packagings. The number of shipments received at the repository increases by $22 \%$ and $64 \%$ respectively for the $50 \%$ truck and all truck al ternatives. The total 20-year transportation cost is reduced about $9 \%$ and $30 \%$ respectively.

TABLE 4.27. Effects of Rail Versus Truck Delivery

\begin{tabular}{|c|c|c|c|c|c|}
\hline & $\begin{array}{l}\text { Base Case } \\
75 \% \text { Rail } \\
\end{array}$ & $\begin{array}{l}50 \% \\
\mathrm{Ra} i 1 \\
\end{array}$ & $\begin{array}{l}\text { Percent } \\
\text { Change } \\
\text { From Base } \\
\end{array}$ & $\begin{array}{l}\text { Al1 } \\
\text { Truck } \\
\end{array}$ & $\begin{array}{l}\text { Percent } \\
\text { Change } \\
\text { From Base } \\
\end{array}$ \\
\hline $\begin{array}{l}\text { Waste Emplacement Rate } \\
\qquad\left(\mathrm{m}^{3} / \text { year }\right)\end{array}$ & 10,000 & 10,000 & 0 & 10,000 & 0 \\
\hline \multicolumn{6}{|l|}{ Shipments per Year } \\
\hline Rail & 320 & 215 & -33 & 0 & -100 \\
\hline Truck & 480 & 760 & +58 & 1,310 & +173 \\
\hline Total & 800 & 975 & +22 & 1,310 & +64 \\
\hline \multicolumn{6}{|l|}{ Packagings Required } \\
\hline Rail TRUPACT & 50 & 36 & -28 & 0 & -100 \\
\hline Truck TRUPACT & 11 & 19 & +73 & 34 & +209 \\
\hline Total & 61 & 55 & -10 & 34 & -44 \\
\hline \multicolumn{6}{|c|}{$\begin{array}{l}20 \text { Year Transportation Cost } \\
(\$ \mathrm{million})\end{array}$} \\
\hline Capital & 12.3 & 10.9 & $9-11$ & 6.6 & -46 \\
\hline Shipping Maintenance & 97.2 & 88.5 & -9 & 70.4 & -28 \\
\hline Total & 109.5 & 99.4 & -9 & 77.0 & -30 \\
\hline \multicolumn{6}{|c|}{ Levelized Unit Cost $\left(\$ / \mathrm{m}^{3}\right)$} \\
\hline 0\% Discount Rate & 552 & 501 & -9 & 387 & -30 \\
\hline 10\% Discount Rate & 633 & 569 & -10 & 433 & -32 \\
\hline
\end{tabular}


Transportation requirements for alternative $\mathrm{CH}$-TRU waste shipping systems are summarized in Table 4.28. These comparisons are based on shipment of untreated retrievably stored wastes in TRUPACTS to a single repository located in the Southwest. Transportation system alternatives considered were: use of truck-size TRUPACTs for both truck and rail (2 or 3 per rail shipment), ATMX railcars and Super Tiger ${ }^{(B)}$ packages instead of TRUPACTs, and use of ATMX railcars for the Rocky Flats boxed waste with TRUPACTs used for all other wastes.

Results for alternative CH-TRU shipping systems show that if only the truck size TRUPACT is available, an increase of about ten percent ( $\$ 10$ million) in 20-year transportation cost occurs. ATMX railcar and Super Tiger ${ }^{\circledR}$ systems could result in 20-year costs of about 41 percent of the costs using TRUPACTS, a reduction of ( $\$ 65$ million). If two ATMX cars are available for shipping the wastes stored in Rocky Flats boxes, the 20 -year costs are reduced by $10 \%$, or $\$ 11$ million. The ATMX car has large cost advantages under existing rail tariff policies. It is treated as an empty railcar on the return trip and is returned at no cost. In addition, only cargo weight is charged in the ATMX railcar, while the TRUPACT packaging weight is charged as well as waste contents included.

Four packaging alternatives for shipping PTRU wastes were considered: LowLevel Solid (base treatment casel, disposable Type B overpack, reusable Type B overpack, and TRUPACT shipping packages. The effects on transportation requirements are summarized in Table 4.29 for a single treatment facility at the INEL, and in Table 4.30 for the case of two treatment facilities located at the INEL and Hanford. In both comparisons, TRUPACT packagings were used for shipping $\mathrm{CH}-\mathrm{TRU}$ waste to the treatment plant, and PTRU waste is shipped to a single repository located in the Southwest. The transportation costs increase 34 and $42 \%$ (over $\$ 30$ million increase) with disposable Type B overpack, more than double (over $\$ 140$ million increase) with reusable Type B overpacks, and increase $84 \%$ to $103 \%$ using the TRUPACT shipping package. The reusable overpack is charged for shipping both ways, while the disposable overpacks are only charged for one way. 
TABLE 4.28. Effects of Alternate $\mathrm{CH}$-TRU Waste Transportation System

\begin{tabular}{|c|c|c|c|c|c|c|c|}
\hline & $\begin{array}{c}\text { Base Case } \\
\text { TRUPACT } \\
\text { Two Sizes } \\
\end{array}$ & $\begin{array}{c}\text { TRUPACT } \\
\text { Truck Size } \\
\text { Only, } 2 \text { or } 3 \\
\text { Per Railcar }\end{array}$ & $\begin{array}{c}\text { Percent } \\
\text { Change } \\
\text { From Base } \\
\end{array}$ & $\begin{array}{c}\text { ATMX } \\
\text { Super Tiger }\end{array}$ & $\begin{array}{c}\text { Percent } \\
\text { Change } \\
\text { From Base } \\
\end{array}$ & $\begin{array}{c}\text { ATMX } \\
\text { IRUPACT } \\
\end{array}$ & $\begin{array}{c}\text { Percent } \\
\text { Change } \\
\text { From Base } \\
\end{array}$ \\
\hline \multicolumn{8}{|l|}{ Shipments Per Year } \\
\hline Rail & 320 & $270^{(a)}$ & -16 & 190 & -41 & 274 & -14 \\
\hline Truck & 480 & 480 & 0 & 480 & 0 & 440 & -8 \\
\hline Total & 800 & 750 & -6 & 670 & -16 & 714 & -11 \\
\hline \multicolumn{8}{|l|}{ Packagings Required } \\
\hline Rail TRUPACT & 50 & 0 & -100 & 0 & -100 & 41 & -18 \\
\hline Truck TRUPACT & 11 & 74 & +570 & 0 & -100 & 10 & -9 \\
\hline ATMX & 0 & 0 & -- & 16 & -- & 2 & -- \\
\hline Super Tiger & 0 & 0 & -- & 11 & -- & 0 & -- \\
\hline Total & 61 & 74 & +21 & 27 & -56 & 53 & -13 \\
\hline \multicolumn{8}{|l|}{$\begin{array}{l}\text { 20-Year Transportation } \\
\text { Cost }(\$ \text { million })\end{array}$} \\
\hline Capital & 12.3 & 14.8 & +20 & 3.8 & -69 & 10.2 & -17 \\
\hline Shipping \& Maintenance & 97.2 & 104.6 & +8 & 40.9 & -58 & 88.1 & -9 \\
\hline Total & 109.5 & 119.4 & +9 & 44.7 & -59 & 98.3 & -10 \\
\hline \multicolumn{8}{|l|}{ Levelized Unit Cost $\left(\$ / \mathrm{m}^{3}\right)$} \\
\hline $0 \%$ Discount & 552 & 602 & +9 & 226 & -59 & 521 & -6 \\
\hline $10 \%$ Discount & 633 & 701 & +11 & 252 & -60 & 574 & -9 \\
\hline
\end{tabular}

(a) Three packagings per rail shipment. 
TABLE 4.29. Effects of Alternate PTRU Transportation System - Single Treatment Facility

\begin{tabular}{|c|c|c|c|c|c|c|}
\hline $\begin{array}{l}\text { Base Case } \\
\text { Low-Level } \\
\text { Solids }\end{array}$ & $\begin{array}{c}\text { Disposable } \\
\text { Type B } \\
\text { Overpack }\end{array}$ & $\begin{array}{l}\text { Percent } \\
\text { Change } \\
\text { From Base }\end{array}$ & $\begin{array}{l}\text { Reuseable } \\
\text { Type B } \\
\text { Overpack }\end{array}$ & $\begin{array}{l}\text { Percent } \\
\text { Change } \\
\text { From Base }\end{array}$ & TRUPACT & $\begin{array}{l}\text { Percent } \\
\text { Change } \\
\text { From Base }\end{array}$ \\
\hline
\end{tabular}

Shipments Per Year

\begin{tabular}{|c|c|c|c|c|c|c|c|}
\hline CH-TRU & & & & & & & \\
\hline Rail & 320 & 320 & 0 & 320 & 0 & 320 & 0 \\
\hline Truck & 480 & 480 & 0 & 480 & 0 & 480 & 0 \\
\hline Total & 800 & 800 & 0 & 800 & 0 & 800 & 0 \\
\hline PTRU & & & & & & & \\
\hline Rail & 190 & 310 & +63 & 420 & +121 & 310 & +63 \\
\hline & 180 & 340 & +89 & 420 & +133 & 340 & +89 \\
\hline Total & 370 & 650 & +76 & 840 & +127 & 650 & +76 \\
\hline Packagings Required & & & & & & & \\
\hline Rail TRUPACT & 17 & 17 & 0 & 17 & 0 & 65 & +280 \\
\hline Truck TRUPACT & 8 & 8 & 0 & 8 & 0 & 17 & +110 \\
\hline Type B Reusable & 0 & 0 & 0 & 432 & -- & 0 & 0 \\
\hline 20-Year Transportation & & & & & & & \\
\hline Cost $(\$$ million $)$ & & & & & & & \\
\hline Capital & 4.9 & 4.9 & 0 & 32.9 & +571 & 16.2 & +230 \\
\hline Shipping and Maintenance & 89.4 & 121.5 & +36 & 201.8 & +126 & 157.7 & +76 \\
\hline Total & 94.3 & 126.4 & +34 & 234.7 & +149 & 173.9 & +84 \\
\hline Level ized Unit Cost $\left(\$ / \mathrm{m}^{3}\right)$ & & & 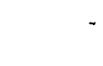 & & & & \\
\hline $0 \%$ Discount & 472 & 633 & +34 & 1,176 & +149 & 871 & +84 \\
\hline 10\% Discount & 738 & 895 & 21 & 1,626 & +120 & 1209 & +64 \\
\hline
\end{tabular}


TABLE 4.30. Effects of Alternate PTRU Transportation Systems - Two Treatment.Facilities

Shipments Per Year

CH-TRU Rail

CH-TRU Truck

CH-TRU Total

PTRU Rail

PTRU Truck

PTRU Total

Packagings Required

Rail TRUPACT

Truck TRUPACT

Type B Reusable

20-Year Transportation

Cost ( $\$$ million)

\section{Capital}

Shipping and Maintenance

Total

Levelized Unit Cost $\left(\$ / \mathrm{m}^{3}\right)$

$0 \%$ Discount

$10 \%$ Discount

\begin{tabular}{|c|c|c|c|c|c|c|}
\hline $\begin{array}{l}\text { Bas } \\
\text { Low }\end{array}$ & $\begin{array}{l}\text { Typ } \\
\text { Over }\end{array}$ & $\begin{array}{l}\mathrm{Pe} \\
\mathrm{Ch}\end{array}$ & $\begin{array}{c}\text { Ty } \\
\text { Ove }\end{array}$ & $\begin{aligned} \mathrm{Pr} \\
\mathrm{Cl}\end{aligned}$ & 「RUPACT & $\begin{array}{l}\text { Perc } \\
\text { Char } \\
\text { From }\end{array}$ \\
\hline
\end{tabular}

$\begin{array}{rrrrrrr}320 & 320 & 0 & 320 & 0 & 320 & 0 \\ 480 & 480 & 0 & 480 & 0 & 480 & 0 \\ 800 & 800 & 0 & 800 & 0 & 800 & 0 \\ 190 & 310 & +63 & 420 & +121 & 310 & +63 \\ 180 & 340 & +89 & 420 & +133 & 340 & +89 \\ 370 & 650 & +76 & 840 & +127 & 650 & +76\end{array}$

8

8

Low-Level

Type B

Overpack

8

8
7

444

2.9

77.8

80.7

$\begin{array}{lr}2.9 & 0 \\ 112 & +44 \\ 114.9 & +42\end{array}$

$31.7+993$

$14.5+400$

$195.9+152$

$227.6+182$

$149.5+92$

$164.0+103$

405

566

$576+42$
738

$738+30$
1,140

1,496

$+181$

822

$+103$

$+88$ 


\subsubsection{Transportation Effects of Regional Repositories}

The effects on transportation requirements due to regional repositories are summarized in Table 4.31. In addition to the western repository in the Southwest, repositories were added to the analys is in the South and in the Northeast. No defense waste is generated in the North Central region. This comparison is made for treatment prior to emplacement in the repositories, with treatment facilities located at Mound Facility in the Northeast, Savannah River in the South, and at INEL in the west. TRUPACT packagings were assumed for CH-TRU shipments and Low-Level Solids for PTRU waste shipments. This regional scenario results in a 16 percent ( $\$ 15$ million) reduction of the 20 -year transportation cost.

\subsubsection{Transportation Effects of Facility Location}

The effects on transportation requirements of alternate repository locations in the western U.S. are summarized in Tables 4.32 through 4.36. In addition to the Southwest location, alternate locations in the Mojave Desert, in the Central Rockies, and in the Northwest were considered.

Table 4.32 manifests the effects when there is a single repository and CH-TRU wastes are emplaced without further treatment. Under these conditions, the Central Rockies location offers the greatest reduction in transportation costs, about $40 \%$ or $\$ 44$ million. The Northwest location is almost as good, with the transportation costs reduced 36\% from the base case. The Mojave Desert location offers a $22 \%$ cost reduction from the base case. The Southwest location is the most expensive location considered in terms of transportation cost.

As shown in Table 4.33, with a single treatment facility at the INEL, the alternate locations are ranked in the same order in terms of reducing transportation cost. The Central Rockies location yields $25 \%$ cost reduction or about $\$ 24 \mathrm{million}$, the Northwest location yields $20 \%$ reduction or $\$ 19 \mathrm{mil1ion}$, and the Mojave Desert location yields $16 \%$ or $\$ 16$ million reduction. With regional repository and treatment, these alternative Western repositories yield a slightly lower reduction in total cost, as shown in Table 4.34. 
TABLE 4.31. Effects of Regional Repositories

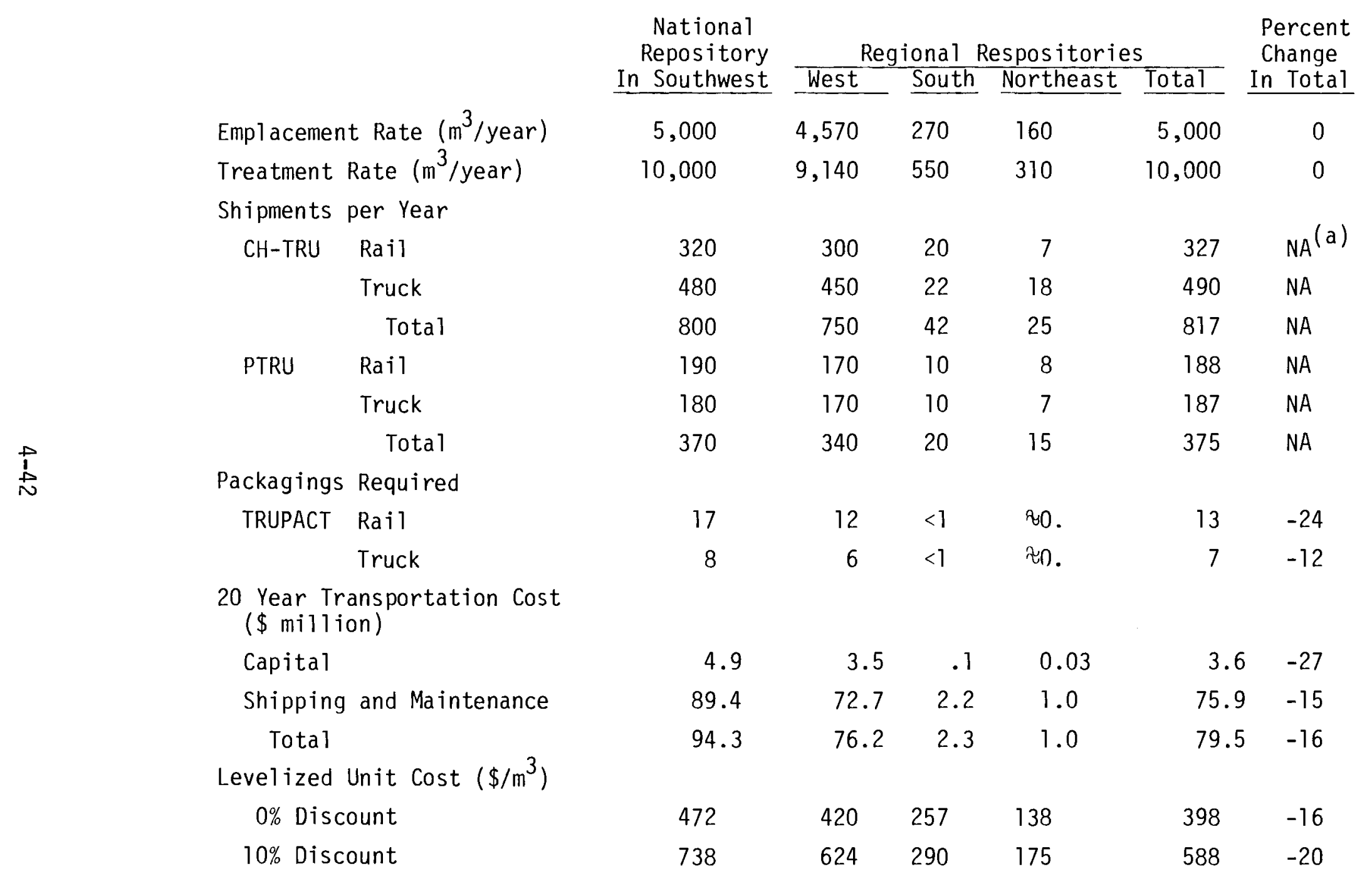

(a) NA = Not Applicable. 
TABLE 4.32. Effects of Alternate Repository Locations - Single Repository with No Treatment

\begin{tabular}{|c|c|c|c|c|c|c|c|}
\hline & $\begin{array}{l}\text { Base Case } \\
\text { Repository in } \\
\text { Southwest }\end{array}$ & $\begin{array}{c}\text { Repository } \\
\text { in Mojave } \\
\text { Desert } \\
\end{array}$ & $\begin{array}{l}\text { Percent } \\
\text { Change } \\
\text { From Base } \\
\end{array}$ & $\begin{array}{l}\text { Repository } \\
\text { in Central } \\
\text { Rockies } \\
\end{array}$ & 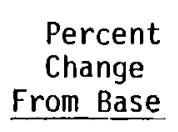 & $\begin{array}{c}\text { Repository } \\
\text { in } \\
\text { Northwest }\end{array}$ & $\begin{array}{r}\text { Percen } \\
\text { Change } \\
\text { From Ba } \\
\end{array}$ \\
\hline \multicolumn{8}{|l|}{ Packagings Required } \\
\hline Rail TRUPACT & 50 & 40 & -20 & 30 & -40 & 31 & -38 \\
\hline Truck TRUPACT & 11 & 11 & 0 & 9 & -18 & 11 & 0 \\
\hline Total & 61 & 51 & -16 & 39 & -36 & 42 & -31 \\
\hline \multicolumn{8}{|l|}{$\begin{array}{l}\text { 20-Year Transportation Cost } \\
(\$ \text { million })\end{array}$} \\
\hline Capital & 12.3 & 10.2 & -17 & 7.8 & -37 & 8.2 & -33 \\
\hline Shipping and Maintenance & 97.2 & 75 & -23 & 57.7 & -41 & 62.2 & -36 \\
\hline Total & 109.5 & 85.2 & -22 & 65.5 & -40 & 70.4 & -36 \\
\hline \multicolumn{8}{|l|}{ Levelized Unit Cost $\left(\$ / \mathrm{m}^{3}\right)$} \\
\hline $0 \%$ Discount & 552 & 430 & -22 & 330 & -40 & 355 & -36 \\
\hline $10 \%$ Discount & 633 & 500 & -21 & 383 & -39 & 401 & -37 \\
\hline
\end{tabular}

$\stackrel{+}{1}$

TABLE 4.33. Effects of Alternate Repository Locations - Single Treatment Facility at the INEL and Single Repository

\begin{tabular}{|c|c|c|c|c|c|c|}
\hline $\begin{array}{l}\text { Base Case } \\
\text { Repository in } \\
\text { Southwest }\end{array}$ & $\begin{array}{l}\text { Repository } \\
\text { in Mojave } \\
\text { Desert }\end{array}$ & $\begin{array}{l}\text { Percent } \\
\text { Change } \\
\text { From Base }\end{array}$ & $\begin{array}{l}\text { Repository } \\
\text { in Central } \\
\text { Rockies } \\
\end{array}$ & $\begin{array}{c}\text { Percent } \\
\text { Change } \\
\text { From Base }\end{array}$ & $\begin{array}{l}\text { Repository } \\
\text { in } \\
\text { Northwest }\end{array}$ & $\begin{array}{l}\text { Percent } \\
\text { Change } \\
\text { From Base }\end{array}$ \\
\hline
\end{tabular}

20-Year Transportation Cost

(\$million)

Capita 1

Shipping and Maintenance

Total

$4.9 \quad 4.9$

$\begin{array}{rr}4.9 & 0 \\ 73.9 & -17\end{array}$

$4.9 \quad 0$

$4.9 \quad 0$

89.4

$78.8-16$

$65.7 \quad-27$

$70.4 \quad-21$

Levelized Unit Cost $\left(\$ / \mathrm{m}^{3}\right)$

$0 \%$ Discount

472

395

$-16$

$70.6-25$

$75.3-20$

$10 \%$ Discount

733

656

$-11$

353

$-25$

$377-20$

10\% Discount 
TABLE 4.34. Effects of Alternate Western Regional Repository Locations - Single Treatment Location at the INEL

\begin{tabular}{|c|c|c|c|c|c|c|}
\hline $\begin{array}{l}\text { Base Case } \\
\text { Repository in } \\
\text { Southwest } \\
\end{array}$ & $\begin{array}{c}\text { Repository } \\
\text { in Mojave } \\
\text { Desert }\end{array}$ & $\begin{array}{l}\text { Percent } \\
\text { Change } \\
\text { From Base }\end{array}$ & $\begin{array}{l}\text { Repository } \\
\text { in Central } \\
\text { Rockies } \\
\end{array}$ & $\begin{array}{c}\text { Percent } \\
\text { Change } \\
\text { From Base } \\
\end{array}$ & $\begin{array}{l}\text { Repository } \\
\text { in } \\
\text { Northwest } \\
\end{array}$ & $\begin{array}{l}\text { Percent } \\
\text { Change } \\
\text { From Base }\end{array}$ \\
\hline
\end{tabular}

20-Year Transportation Cost

\begin{tabular}{|c|c|c|c|c|c|c|c|}
\hline Capital & 3.5 & 3.5 & 0 & 3.5 & 0 & 3.5 & 0 \\
\hline Shipping and Maintenance & 72.7 & 58.7 & -19 & 51.2 & -30 & 55.4 & -24 \\
\hline Total & 76.2 & 62.2 & -18 & 54.7 & -28 & 58.9 & -23 \\
\hline \multicolumn{8}{|l|}{ evelized Unit Cost $\left(\$ / \mathrm{rit}^{3}\right)$} \\
\hline $0 \%$ Discount & 420 & 342 & -18 & 302 & -28 & 325 & -23 \\
\hline 10\% Discount & 624 & 546 & -12 & 505 & -19 & 528 & -15 \\
\hline
\end{tabular}

TABLE 4.35. Effects of Alternate Repository Locations - Two Treatment Facilities at the INEL

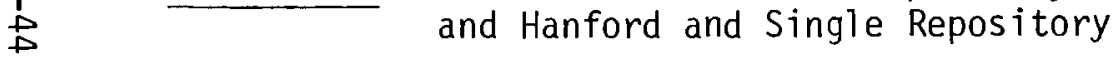

\begin{tabular}{|c|c|c|c|c|c|c|c|}
\hline & $\begin{array}{l}\text { Base Case } \\
\text { Repository in } \\
\text { Southwest }\end{array}$ & $\begin{array}{l}\text { Repository } \\
\text { in Mojave } \\
\text { Desert } \\
\end{array}$ & $\begin{array}{l}\text { Percent } \\
\text { Change } \\
\text { From Base }\end{array}$ & $\begin{array}{l}\text { Repository } \\
\text { in Central } \\
\text { Rockies } \\
\end{array}$ & 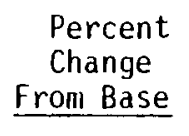 & $\begin{array}{c}\text { Repository } \\
\text { in } \\
\text { Northwest } \\
\end{array}$ & $\begin{array}{l}\text { Percent } \\
\text { Change } \\
\text { From Base } \\
\end{array}$ \\
\hline \multicolumn{8}{|l|}{$\begin{array}{l}\text { 20-Yeár Transportation Cost } \\
(\$ \text { million) }\end{array}$} \\
\hline Capital & 2.9 & 2.9 & 0 & 2.9 & 0 & 2.9 & 0 \\
\hline Shipping and Haintenance & 77.8 & 62.6 & -20 & 54.9 & -29 & 49.9 & -36 \\
\hline Total & 80.7 & 65.5 & -19 & 57.8 & -28 & 52.8 & -35 \\
\hline \multicolumn{8}{|l|}{ Level ized Unit Cost $\left(\$ / \mathrm{m}^{3}\right)$} \\
\hline $0 \%$ Discount & 405 & 328 & -19 & 290 & -28 & 265 & -35 \\
\hline $10 \%$ Discount & 566 & 490 & -13 & 451 & -20 & 425 & -25 \\
\hline
\end{tabular}


TABLE 4.36. Effects of Locating Treatment Facility at Repository

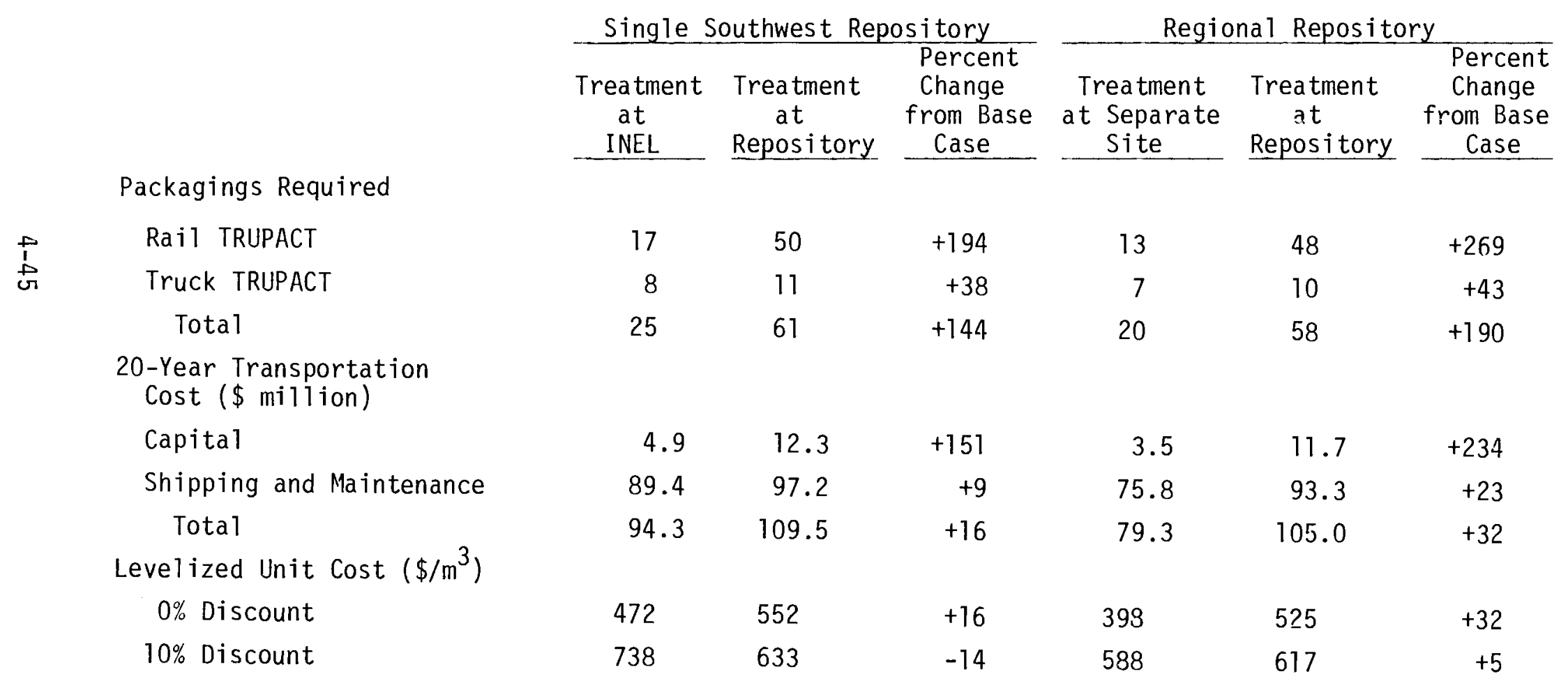


With two treatment locations at the INEL and Hanford and a single national repository, the alternate repository locations are reordered in terms of transportation benefits. The Northwest location yields the largest transportation cost reduction of $35 \%$ or $\$ 28$ million, followed by the Central Rockies location yielding a $28 \%$ or $\$ 23$ million reduction, followed by the Mojave Desert location yielding a $19 \%$ or $\$ 15$ million reduction. This information is summarized in Table 4.35 .

Table 4.36 summarizes the effects on transportation requirements if the treatment facility is co-located with the repository. For this comparison, the Western repository was located in the Southwest. Co-location results in an increase of transportation costs under these conditions compared with locating the treatment facility at the INEL. With a single national repository, the transportation costs increase $16 \%$ or about $\$ 15$ million. With regional repositories, transportation costs increase $32 \%$ or $\$ 26$ million.

\subsubsection{Sensitivity Analysis}

Table 4.37 illustrates the sensitivity of transportation requirements to changes in some basic values used in the analysis. These sensitivity calculations were based on shipping CH-TRU waste in TRUPACT packagings to a single repository in the Southwest with no treatment. Under these conditions, packaging capital accounts for $11 \%$ of the total transportation cost, so halving the packaging lifetime results in an $11 \%$ increase in the total transportation costs. An arbitrary increase of $25 \%$ in travel time for all links increases packaging requirements $21 \%$ and total cost by $3 \%$. An arbitrary increase of two days in loading/unloading time (doubles loading/unloading time from base case) increases packaging requirements $15 \%$ and total transportation cost about $2 \%$. These result from changes in transit time and turnaround time imply that under the basic assumed conditions, packagings are in transit about $85 \%$ of the time and are loading and unloading about $15 \%$ of the time. Doubling the basic maintenance costs used in the analysis increases total transportation cost about $3 \%$. 
TABLE 4.37. Sensitivity of Transportation Requirements to Changes in Basic Values

\begin{tabular}{|c|c|c|c|c|c|c|c|c|c|}
\hline & $\begin{array}{l}\text { Base } \\
\text { Case }\end{array}$ & $\begin{array}{l}\text { Decrease } \\
\text { Packaging Life } \\
\text { From } 20 \text { Years } \\
\text { to } 10 \text { Years (a) } \\
\end{array}$ & $\begin{array}{l}\text { Percent } \\
\text { Change }\end{array}$ & $\begin{array}{c}25 \% \text { Increase } \\
\text { in Transit } \\
\text { Time } \\
\end{array}$ & $\begin{array}{l}\text { Percent } \\
\text { Change } \\
\end{array}$ & $\begin{array}{l}\text { Add } 2 \text { Days } \\
\text { to Turn- } \\
\text { Around Time } \\
\end{array}$ & $\begin{array}{l}\text { Percent } \\
\text { Change }\end{array}$ & 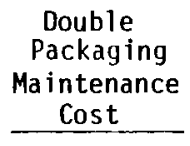 & $\begin{array}{l}\text { Percent } \\
\text { Change } \\
\end{array}$ \\
\hline \multicolumn{10}{|l|}{$\begin{array}{l}\text { Packagings Required } \\
\text { in Service }\end{array}$} \\
\hline Rail TRUPACT & 50 & 50 & 0 & 61 & +22 & 55 & +10 & 50 & 0 \\
\hline Truck TRUPACT & 11 & 11 & 0 & 13 & +18 & 15 & +36 & 11 & 0 \\
\hline Total & 61 & 61 & 0 & 74 & +21 & 70 & +15 & 61 & 0 \\
\hline \multicolumn{10}{|l|}{$\begin{array}{l}\text { 20-Year Transportation } \\
\text { Cost }(\$ \text { million) }\end{array}$} \\
\hline Capital & 12.3 & 24.4 & +98 & 14.9 & +21 & 14.1 & +15 & 12.3 & 0 \\
\hline Shipping \& Ma intenance & 97.2 & 97.2 & 0 & 97.9 & +1 & 97.7 & +1 & 100.2 & +3 \\
\hline Total & 109.5 & 121.6 & +11 & 112.8 & +3 & 111.8 & +2 & 112.5 & +3 \\
\hline \multicolumn{10}{|l|}{ Levelized Unit Cost $\left(\$ / \mathrm{m}^{3}\right)$} \\
\hline $0 \%$ & 552 & 614 & +11 & 569 & +3 & 564 & +2 & 568 & +3 \\
\hline $10 \%$ Discount & 633 & 689 & +9 & 667 & +5 & 657 & +4 & 649 & +3 \\
\hline
\end{tabular}

(a) The number of packagings in service is constant but the total number purchased doubles since they are retired faster. 


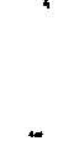




\subsection{HIGH-LEVEL DEFENSE WASTES TRANSPORTATION}

High-level defense wastes (HLDW) orginate from the chemical processing of irradiated nuclear fuels and targets. Due to the high activity of the associated fission products in the HLDW, these wastes require remote handling and heavily shielded facilities and transport casks. This section is divided into a discussion of the sources and generation rates of HLDW, a description of transportation and packaging systems, scenarios for HLDW transportation, HLDW shipping costs and transit times and HLDW transportation costs and logistics.

\subsection{HIGH-LEVEL DEFENSE WASTES SOURCES AND VOLUMES}

Nearly all of the existing HLDW in the United States have been generated in defense activities at four sites: the Hanford plant near Richland, Washington; the Savannah River Plant (SRP) near Aiken, South Carolina; the Idaho Chemical Processing Plant (ICPP) near Idaho Falls, Idaho; and the Nuclear Fuel Services Plant in West Valley, New York. For this analysis, it was assumed that treatment of HLDW would occur at each site as a means of improving radionuclide retention for safe transportation and emplacement in a waste repository for long-term isolation.

Each site is considering different size canisters, as shown in Table 5.1. Because the treatment facilities for HLDW are under development, various canister sizes are currently being investigated to arrive at an efficient

TABLE 5.1. HLDW Canister Production

$$
\begin{aligned}
& \text { Canister Size } \\
& \text { Starting Year } \\
& \text { Annual Production Rate } \\
& \text { (canisters) } \\
& \text { Annual Production Rate } \\
& \left(m^{3}\right)
\end{aligned}
$$

\begin{tabular}{|c|c|c|c|c|}
\hline SRP & Hanford & \multicolumn{2}{|c|}{ ICPP } & NFS \\
\hline $.61 \mathrm{~m} \mathrm{dia} \times 3.0 \mathrm{~m}$ & $.61 \mathrm{~m} \mathrm{dia} \times 3.7 \mathrm{~m}$ & $\begin{array}{c}61 \mathrm{~m} \mathrm{did} \\
2000\end{array}$ & $\begin{array}{l}\times 4.6 \mathrm{~m} \\
2015\end{array}$ & $.61 \mathrm{~m} \mathrm{dia} \times 3.0 \mathrm{~m}$ \\
\hline 511 & 960 & 1190 & 435 & $300^{(b)}$ \\
\hline 454 & 1010 & 1590 & 580 & $244^{(b)}$ \\
\hline
\end{tabular}

(a) $1 \mathrm{~m}=3.281 \mathrm{ft}$.

(b) Nuclear Fuel Services provides a total backlog of $244 \mathrm{~m}^{3}$ with zero future production. 
configuration for disposal. For the purpose of this analysis, when alternate canister sizes are used, it is assumed that waste volume production rates remain constant as shown in Table 5.1 .

\subsection{HIGH-LEVEL DEFENSE WASTES SHIPPING SYSTEMS}

Conceptual HLDW shipping cask designs for the transport of waste canisters described in Section 5.1 are being developed by General Atomic under contract to the TTC. Alternative canister dimensions were considered here to determine transportation cost tradeoffs in support of the cask design. All cask designs are constrained by maximum shipping weights of $86,300 \mathrm{~kg}$ by rai1 and $22,700 \mathrm{~kg}$ by truck. Actual weights are determined by cask capacities and structural materials. Cask characteristics for alternative canister sizes were developed by J. A. Bucholz at ORNL using the SCALE computer program. Table 5.2 shows the 12 cask concepts considered in this analysis. The HLDW were assumed to have a density of $1800 \mathrm{~kg} / \mathrm{m}^{3}$ and a heat generation rate of $600 \mathrm{~W} / \mathrm{m}^{3}$.

TABLE 5.2. HLDW Shipping Casks

\begin{tabular}{|c|c|c|c|c|c|c|c|c|c|c|c|c|}
\hline \multirow[b]{3}{*}{$\begin{array}{c}\text { Cask } \\
\text { Concept }\end{array}$} & \multirow{2}{*}{\multicolumn{2}{|c|}{$\begin{array}{c}\text { Canister } \\
\text { Size }\end{array}$}} & \multicolumn{5}{|c|}{ Truck } & \multicolumn{5}{|c|}{ Rail } \\
\hline & & & \multirow{2}{*}{$\begin{array}{l}\text { Cans } \\
\text { per } \\
\text { Load } \\
\end{array}$} & \multirow[b]{2}{*}{$\begin{array}{c}\text { Shield } \\
\text { Material } \\
\end{array}$} & \multirow{2}{*}{$\begin{array}{l}\text { Was te } \\
\text { Volume } \\
\left(\mathrm{m}^{3}\right) \\
\end{array}$} & \multirow{2}{*}{$\begin{array}{l}\text { Loaded } \\
\text { Cask } \\
\text { Weight } \\
(\mathrm{kg}) \\
\end{array}$} & \multirow{2}{*}{$\begin{array}{r}\text { Cask } \\
\text { Cost } \\
\left(\$ 10^{6}\right) \\
\end{array}$} & \multirow{2}{*}{$\begin{array}{l}\text { Cans } \\
\text { per } \\
\text { Load } \\
\end{array}$} & \multirow[b]{2}{*}{$\begin{array}{c}\text { Shield } \\
\text { Material } \\
\end{array}$} & \multirow{2}{*}{$\begin{array}{l}\text { Waste } \\
\text { Vol ume } \\
\left(\mathrm{m}^{3}\right)\end{array}$} & \multirow{2}{*}{$\begin{array}{c}\text { Loaded } \\
\text { Cask } \\
\text { Weight } \\
(\mathrm{kg}) \\
\end{array}$} & \multirow{2}{*}{$\begin{array}{r}\text { Cask } \\
\text { Cost } \\
\left(\$ 10^{6}\right) \\
\end{array}$} \\
\hline & $\begin{array}{l}\text { Diameter } \\
\text { (In) })^{(a)^{-1}}\end{array}$ & $\begin{array}{l}\text { Length } \\
(\mathrm{m})^{\text {(a) }}\end{array}$ & & & & & & & & & & \\
\hline 1 & .30 & 2.4 & 3 & $\mathrm{~Pb}$ & 0.42 & 22,600 & 0.43 & 31 & $\mathrm{Fe}$ & 4.28 & 83,600 & 1.23 \\
\hline 2 & .46 & 2.4 & 1 & $\mathrm{Fe}$ & 0.334 & 15,200 & 0.34 & 14 & $\mathrm{Fe}$ & 4.55 & 84,800 & 1.25 \\
\hline 3 & .46 & 3.0 & 1 & $\mathrm{Fe}$ & 0.401 & 18,100 & 0.41 & 14 & U & 5.69 & 85,200 & 1.92 \\
\hline 4 & .46 & 3.7 & 1 & $\mathrm{Fe}$ & 0.491 & 21,400 & 0.48 & 11 & u & 5.37 & 83,400 & 1.88 \\
\hline 5 & .46 & 4.6 & 1 & u & 0.602 & 18,000 & 0.78 & 7 & $\mathrm{Fe}$ & 4.28 & 83,700 & 1.23 \\
\hline 6 & .61 & 2.4 & 1 & $\mathrm{Fe}$ & 0.580 & 19,400 & 0.44 & 8 & $\mathrm{Fe}$ & 4.68 & 81,700 & 1.07 \\
\hline 7 & .61 & 3.0 & 1 & U & 0.736 & 16,900 & 0.74 & 7 & $\mathrm{Fe}$ & 5.17 & 87,300 & 1.21 \\
\hline 8 & .61 & 3.7 & 1 & U & 0.892 & 20,000 & 0.87 & 7 & U & 6.20 & 82,600 & 1.86 \\
\hline 9 & .61 & 4.6 & -- & -- & -- & -- & -- & 4 & U & 4.44 & 74,400 & 1.68 \\
\hline 10 & .91 & 2.4 & 1 & U & 1.36 & 21,900 & 0.95 & 4 & U & 5.42 & 87,900 & 1.98 \\
\hline 11 & 1.2 & 1.2 & 1 & U & 1.25 & 21,800 & 0.95 & 4 & U & 5.0 & 87,400 & 3.8 \\
\hline 12 & 1.2 & 1.2 & -- & -- & -- & -- & -- & 4 & $\mathrm{Fe}$ & 5.0 & 78,800 & 1.16 \\
\hline
\end{tabular}

(a) $1 \mathrm{~m}=3.281 \mathrm{ft}$. 


\subsection{HIGH-LEVEL DEFENSE WASTES SHIPMENT SCENARIOS}

Alternatives are currently being considered for storage, treatment and disposal of HLDW by the U.S. Department of Energy. Final decisions on waste management options are not planned for some time. Thus, for this study, several waste management program alternatives were developed to include changes in future waste transportation system demands. The alternatives considered for HLDW include:

- respository policy alternatives

- transportation systems alternatives

- facility siting strategy alternatives.

Scenarios for HLDW transportation, like contact-handled defense wastes, were categorized based on the repository siting strategies of national and regional repositories. National repository scenarios assume a single waste disposal facility at various locations in the U.S. Cases with a single repository located in the Southwest, Northwest, Mojave Desert or Central Rockies were considered.

Regional repositories assumed multiple waste disposal facilities serving various sections of the U.S. Both four-region and two-region cases were considered. The four-region case was shown in Figure 4.2. The two-region scenario postulated repositories in the Northwest and Northeast. Inter-regional waste shipments were not allowed in the regional repository scenarios.

Transportation of HLDW requires that the wastes be solidified and placed in canisters. Heavily shielded shipping casks must be used for transporting the canisters. Transportation cost and logistics tradeoffs were evaluated for various canister sizes and associated casks designed for efficiently transporting that particular canister size. The 12 cask concepts evaluated in this study were introduced in Table 5.2. Studies to determine the impact of transport mode and repository locations, similar to those for $\mathrm{CH}-$ TRU wastes, were also performed for HLDW. Results of the analyses are presented in Section 5.5. 


\subsection{HIGH-LEVEL DEFENSE WASTES SHIPPING COSTS AND TRANSIT TIMES}

Fees charged by the carriers to ship any cargo is a function of the cargo type (hazardous, nonhazardous, etc.), cargo weight, physical configuration, distance, and frequency or number of shipments. The total turnaround time are controlled by the distance traveled, mode of shipment (truck or rai1), endpoint loading and unloading times, and route characteristics. For HLDW, the costs are affected by the repository locations and shipping casks weights and physical configurations. The turnaround time (total round trip time) can also be affected by differences in weight and configuration due to changes in the endpoint loading and unloading time. It was assumed, for the reference case, that turnaround time is equal to twice the one way transit time plus 2 days for loading and unloading.

Shipping costs from Savannah River, Idaho Falls, and Hanford to the Southwest repository and from Savannah River and Idaho Falls to the Northwest repository, were developed by the DOE traffic managers at Hanford. These costs are shown in Table 5.3. Extrapolations of these costs were used to develop the necessary costs to the alternate repositories and from West valley to all repositories. A11 of these costs assume that the shipping casks will fit a standard $2.4 \mathrm{~m}$ wide trailer for truck and plate "B" specifications for rail.

As in the CH-TRU and PTRU wastes analyses, the truck shipping costs for HLDW do not vary with weight. Consequently, the cost to ship by truck did not change when alternative canister and cask sizes were used in the HLDW analysis. Truck shipping costs are the same as for CH-TRU wastes, Table 4.16. Rail costs do vary with weight. These variances are shown in Table 5.3 in dollars per kilogram. Note that empty casks used for hauling radioactive wastes are transported at a lesser cost than when loaded. This reflects the decreased risks and associated insurance requirements of the carrier.

Shipping times are the same as used for the CH-TRU wastes analysis. Canister and cask weights used for the HLDW analysis are described in Table 5.4. The HLDW shipping rates are based on these cask weights and the shipping costs in Tables 4.16 and 5.3 . 
TABLE 5.3. Rail Shipping Costs for HLDW

Rail Shipments $\quad \frac{\text { Cost/Kilogram }}{\text { Loaded Empty }} \underline{\text { Cost/100 } 1 \mathrm{~b}^{(\mathrm{b})}}$

Between Southwest Repository and:

$\begin{array}{lllll}\text { Savannah River } & \$ .167 & \$ .157 & \$ 7.59 & \$ 7.12 \\ \text { Idaho Falls } & \$ .192 & \$ .180 & \$ 8.72 & \$ 8.18 \\ \text { Richland } & \$ .231 & \$ .217 & \$ 10.47 & \$ 9.83\end{array}$

Between Northwest Repository and:

Savannah River

Idaho Falls
$\$ .274$

$\$ .119$
$\$ .257$

$\$ .112$
$\$ 12.43 \$ 11.65$

$\$ 5.38 \$ 5.06$

(a) 1 kilogram $=2.2051 \mathrm{~b}$.

(b) 1 pound $=.4536 \mathrm{~kg}$.

TABLE 5.4. HLDW Cask Specifications

\begin{tabular}{|c|c|c|c|c|c|c|c|c|}
\hline \multirow[t]{2}{*}{$\begin{array}{c}\text { Cask } \\
\text { Concept } \\
\end{array}$} & \multicolumn{2}{|c|}{$\begin{array}{c}\text { Canister } \\
\text { Size }\end{array}$} & \multicolumn{3}{|c|}{ Truck } & \multicolumn{3}{|c|}{ Rail } \\
\hline & $\begin{array}{c}\text { Diameter } \\
\mathrm{m}(a)\end{array}$ & $\begin{array}{c}\text { Length } \\
\mathrm{m}(\mathrm{a})\end{array}$ & $\begin{array}{c}\text { Canister } \\
\text { Wejght } \\
\mathrm{kg}(\mathrm{B}) \\
\end{array}$ & $\begin{array}{l}\text { Cask } \\
\text { Weight } \\
\text { Empty } \\
\mathrm{kg}(\mathrm{b}) \\
\end{array}$ & $\begin{array}{r}\text { Cask } \\
\text { Cost } \\
\left(\$ 10^{6}\right) \\
\end{array}$ & $\begin{array}{c}\text { Canister } \\
\text { Wejght } \\
\mathrm{kg}(\mathrm{B})\end{array}$ & $\begin{array}{l}\text { Cask } \\
\text { Weight } \\
\text { Empty } \\
\mathrm{kg}(\mathrm{b}) \\
\end{array}$ & $\begin{array}{r}\text { Cask } \\
\text { Cost } \\
\left(\$ 10^{6}\right) \\
\end{array}$ \\
\hline 1 & .30 & 2.4 & 860 & 21,804 & 0.43 & 8,722 & 74,914 & 1.23 \\
\hline 2 & .46 & 2.4 & 682 & 14,503 & 0.34 & 9,272 & 75,514 & 1.25 \\
\hline 3 & .46 & 3.0 & 818 & 17,303 & 0.41 & 11,602 & 73,614 & 1.92 \\
\hline 4 & .46 & 3.7 & 909 & 20,404 & 0.48 & 10,902 & 72,514 & 1.88 \\
\hline 5 & .46 & 4.6 & 1,230 & 16,803 & 0.78 & 8,734 & 75,014 & 1.23 \\
\hline 6 & .61 & 2.4 & 1,180 & 18,203 & 0.44 & 9,542 & 72,214 & 1.07 \\
\hline 7 & .61 & 3.0 & 1,500 & 15,403 & 0.74 & 11,409 & 71,814 & 1.21 \\
\hline 8 & .61 & 3.7 & 1,820 & 18,203 & 0.87 & 12,602 & 70,013 & 1.86 \\
\hline 9 & .61 & 4.6 & -- & -- & -- & 9,042 & 65,412 & 1.68 \\
\hline 10 & .91 & 2.4 & 2,771 & 19,104 & 0.95 & 11,002 & 76,915 & 1.98 \\
\hline 11 & 1.2 & 1.2 & 2,551 & 19,304 & 0.95 & 10,202 & 77,215 & 3.80 \\
\hline 12 & 1.2 & 1.2 & -- & -- & -- & 10,202 & 68,613 & 1.16 \\
\hline
\end{tabular}

(a) 1 meter $=3.281$ feet.

(b) $1 \mathrm{kilogram}=2.205$ pounds. 
The shipping times and mileages, between the HLDW origin-destination combinations, are presented in Tables 5.5 and 5.6. Rail shipping costs for the HLDW cask (concept-7) reference case, are shown in Table 5.7 and the costs for the alternate cases can be found in Table 5.8. Shipping costs for HLDW truck shipments are shown in Table 5.9 .

\subsection{RESULTS OF HIGH-LEVEL DEFENSE WASTES TRANSPORTATION COST AND LOGISTICS ANALYSES}

Results of this HLDW transportation cost and logistics study include information on total transportation costs, levelized costs per unit of waste volume, annual shipments by transport mode, transport cask requirements, and required facility volume throughputs. Only costs related to transporting the wastes are included. Treatment, canister and disposal costs, which may be larger than the transportation costs, are not included. Transportation costs include purchase and maintenance of casks and fees paid for transporting the material. Repositories receiving high-level wastes were assumed to operate for 25 years, so the transportation costs were generated and levelized for that period.

The results of the analysis of transportation requirements to transport HLDW are presented in the following sequence. First the transportation requirements for shipping HLDW to a repository located in the northwest are presented in Section 5.5.1. This represents the base case. Then the effects of alternate HLDW canister size and shipping cask designs are presented in Section 5.5.2. Tradeoffs between truck and rail transit mode are discussed in Section 5.5.3. Changes in transportation requirements due to additional repositories are presented in Section 5.5.4. The effects on transportation requirements of selecting alternate repository locations are presented in Section 5.5.5.

\subsubsection{Transportation Requirements for HLDW Reference Case}

The expected HLDW production rates were shown in Table 5.1, with SRP starting in 1992, Hanford in 1995, ICPP in year 2000, and NFS with a one-time production in 1990. The repository is expected to begin operations in 1997. Alternative HLDW canister sizes and shipping cask designs being considered for implementation were shown in Table 5.2. Cask concept 7, carrying 7 waste 
TABLE 5.5. Transit Times to Regional and Alternate Western HLDW Repositories, Days

\begin{tabular}{|c|c|c|c|c|c|c|c|c|c|c|c|c|}
\hline \multirow[b]{3}{*}{ From } & \multicolumn{12}{|c|}{ To } \\
\hline & \multicolumn{2}{|c|}{ Southwest } & \multicolumn{2}{|c|}{ Northwest } & \multirow{2}{*}{$\begin{array}{l}\text { Central } \\
\text { Truck }\end{array}$} & \multirow{2}{*}{$\begin{array}{c}\text { Rockies } \\
\text { Rail } \\
\end{array}$} & \multirow{2}{*}{$\begin{array}{l}\text { Mojave } \\
\text { Truck }\end{array}$} & \multirow{2}{*}{$\begin{array}{c}\text { Desert } \\
\text { Rail }\end{array}$} & \multicolumn{2}{|c|}{ South } & \multicolumn{2}{|c|}{ Northeast } \\
\hline & Truck & Rail & Truck & Rail & & & & & Truck & Rail & Truck & Rai1 \\
\hline Idaho & 2.2 & 8.6 & 1.1 & 4.8 & .9 & 3.6 & 1.4 & 5.5 & - & -- & - & -- \\
\hline Hanford & 3.1 & 9.3 & -- & - & 1.8 & 6.8 & 2.0 & 8.1 & -- & - & - & -- \\
\hline Savannah River & 2.9 & 9.0 & 5.3 & 10.8 & 4.0 & 9.5 & 4.6 & 10.5 & 1.1 & 4.4 & -- & 6.4 \\
\hline West Valley, NY & 3.6 & 9.3 & 4.9 & 10.5 & 4.0 & 9.5 & 5.4 & 10.9 & -- & -- & .4 & 1.4 \\
\hline
\end{tabular}

TABLE 5.6. Distances to Regional and Alternate Western HLDW Repositories, Kilometers (a)

\begin{tabular}{|c|c|c|c|c|c|c|c|c|c|c|c|c|}
\hline \multirow[b]{3}{*}{ From } & \multicolumn{12}{|c|}{ To } \\
\hline & \multicolumn{2}{|c|}{ Southwest } & \multicolumn{2}{|c|}{ Northwest } & \multirow{2}{*}{$\begin{array}{c}\text { Central } \\
\text { Truck }\end{array}$} & \multirow{2}{*}{$\begin{array}{c}\text { Rockies } \\
\text { Rail } \\
\end{array}$} & \multirow{2}{*}{$\begin{array}{l}\text { Mojave } \\
\text { Truck }\end{array}$} & \multirow{2}{*}{$\begin{array}{l}\text { Desert } \\
\text { Rail }\end{array}$} & \multicolumn{2}{|c|}{ South } & \multicolumn{2}{|c|}{ Northeast } \\
\hline & Truck & Rail & Truck & Rail & & & & & Truck & Rail & Truck & Rail \\
\hline Idaho & 1,789 & 2,156 & 848 & 941 & 721 & 689 & 1,150 & 1,118 & -- & -- & -- & -- \\
\hline Hanford & 2,481 & 2,936 & -- & -- & 1,450 & 1,469 & 1,638 & 1,899 & -- & -- & -- & -- \\
\hline Savannah River & 2,299 & 2,341 & 4,290 & 4,288 & 3,200 & 3,186 & 3,664 & 4,087 & 895 & 853 & -- & 1,356 \\
\hline West Valley, NY & 2,930 & 2,877 & 3,940 & 4,063 & 3,202 & -- & 3,130 & 4,397 & -- & -- & 290 & 257 \\
\hline
\end{tabular}

$\overline{\text { (a) } 1 \text { kilometer }}=0.6214$ miles.

TABLE 5.7. Rail HLDW Shipping Costs for Cask Concept 7 (Reference Case)

\begin{tabular}{|c|c|c|c|c|c|c|}
\hline & & & \$/Roundtrif & To & & \\
\hline From & Southwest & Northwest & Central Rockies & Mojave Desert & South & Northeast \\
\hline Idaho & 28,775 & 17,774 & 16,428 & 19,460 & -- & -- \\
\hline Hanford & 34,563 & -- & 21,929 & 24,960 & -- & -- \\
\hline Savannah River & 25,046 & 41,001 & 34,053 & 40,405 & 17,570 & 21,133 \\
\hline West Valley, NY & 31,874 & 40,217 & 33,645 & 42,585 & -- & 13,382 \\
\hline
\end{tabular}


TABLE 5.8. Rail HLDW Shipping Costs for Alternate Cask Concepts

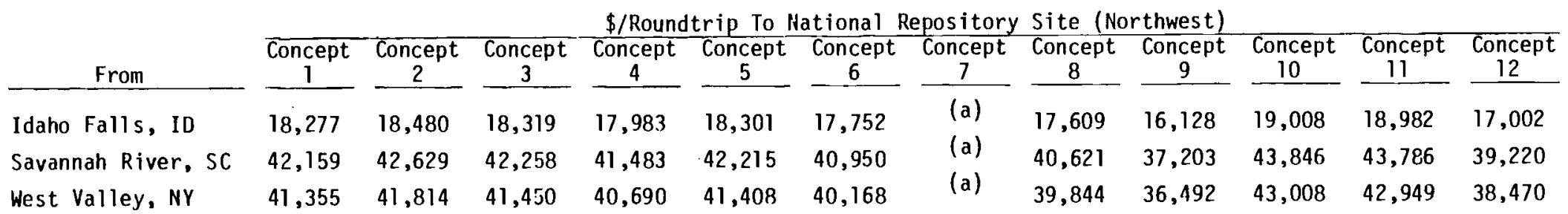

(a) See Table 5.7.

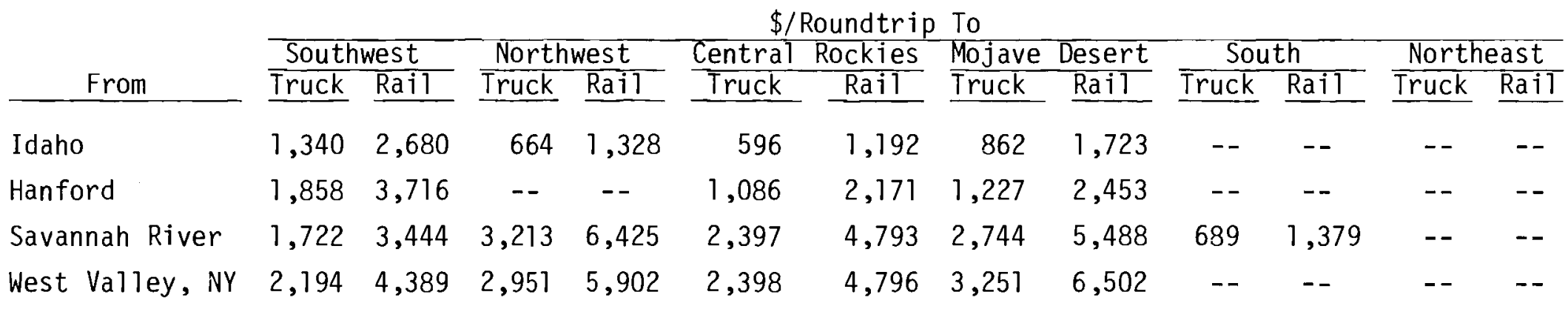


canisters by rail measuring $.61 \mathrm{~m}$ in diameter by $3 \mathrm{~m}$ 1ong, was assumed for the reference case. Al1 HLDW were assumed shipped by rail in the reference case. The shipping costs and transit times used were presented in Section 5.4.

Under these basic conditions, 590 shipments per year will be received at the repository, requiring 23 shipping casks. The capital outlay required is $\$ 27.1$ million and the 25 years shipping and maintenance cost is $\$ 202$ million. The levelized cost is $\$ 3380$ per cubic meter of HLDW at $0 \%$ discount, and $\$ 4000$ at $10 \%$ discount rate.

\subsubsection{Effects on HLDW Transportation Requirements Caused by Alternate Canister Sizes and Shipping Cask Designs}

The effects on HLDW transportation requirements for all twelve rail cask concepts are summarized in Table 5.10. The characteristics of the twelve cask concepts were shown in Table 5.2. The least efficient cask concepts in terms of total transportation cost were concepts 1 and 5 , which resulted in increases of $24 \%$ from the reference case, concept 7 . The most efficient cask concept in terms of transportation cost was concept 8 , which resulted in a cost decrease of $11 \%$. The number of shipping casks required ranges from 19 to 27 , and the number of shipments to process each year ranges from 490 to 710 . The total transportation costs range from $\$ 203$ million to $\$ 284$ miliion.

\subsubsection{Effects on HLDW Transportation Requirements Due to Truck Versus $\underline{\text { Rail Shipments }}$}

Table 5.11 exhibits the effect on HLDW transportation requirements if half of the HLDW is shipped by truck instead of rail. This effect is shown for both cask concept 7 (the reference case) and cask concept 11 ( $1.2 \mathrm{~m} \times 1.2 \mathrm{~m}$ canister size). A truck shipment carries one of either concept-7 or 11 canister, and a rail shipment carries 7 concept-7 canisters or 4 concept-11 canisters. Shipping by truck requires many more shipments to be handled but does offer a reduction in total transportation costs. Reductions total $\$ 10$ million with the concept-7 canisters and $\$ 55$ mil1ion with the concept-11 canister. 
TABLE 5.10. HLDW Transportation Effects Due to Alternate Canister Size and Shipping Cask Design (Percentage Change From Base is Shown in Parenthesis)

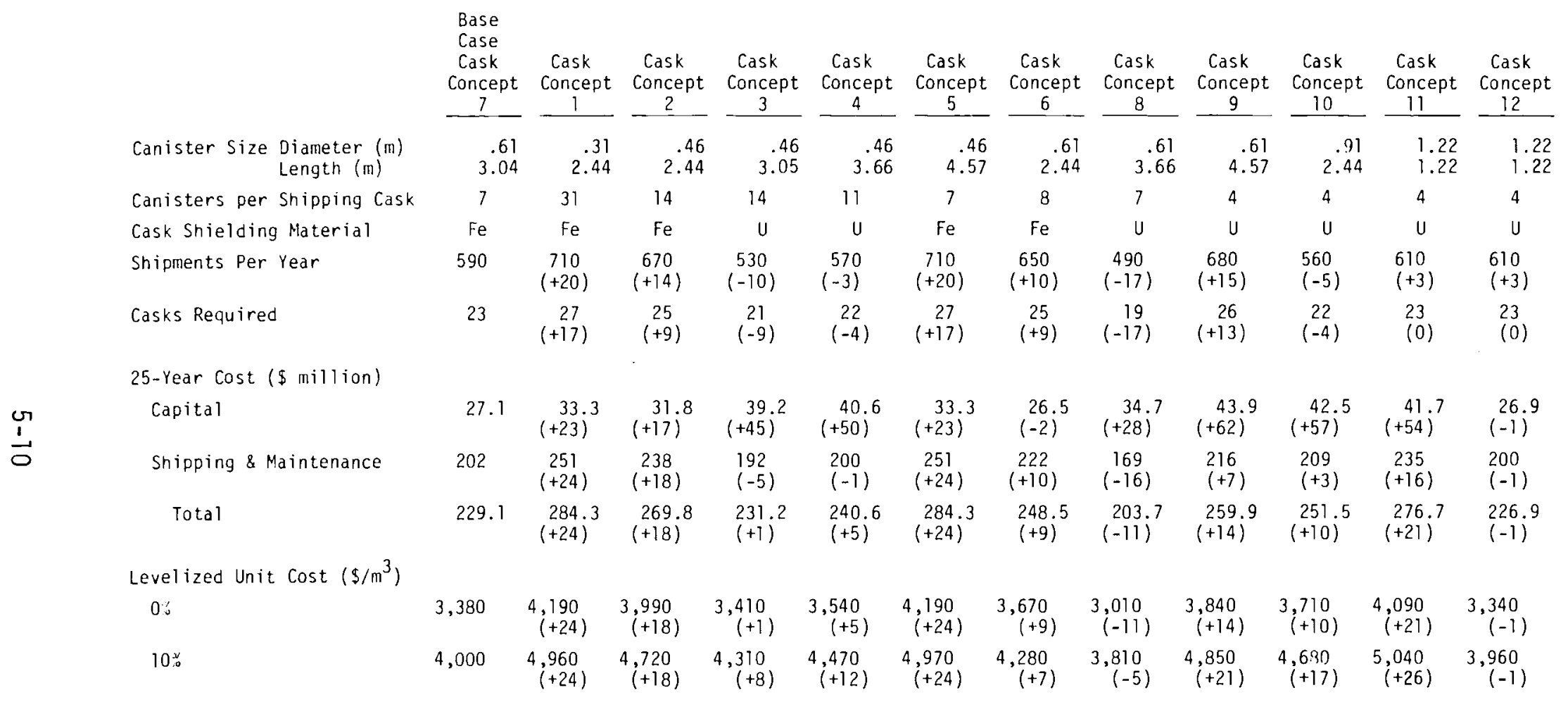


TABLE 5.11. HLDW Transportation Effects if 50\% HLW Volume is Shipped By Truck Instead of All Rail Shipments (Percent Change is Shown in Parenthesis)

Canister Size Diameter $(m)$ Length $(m)$

Cask Concept 7 A11 Rai1 50\% Truck
.61

3.04
.61

3.04
Cask Concept 11

A1T Rail 50\% Truck

1.22

1.22
1.22

1.22

Truck Shipping Cask Design

Canisters per Cask

Shielding Material

Shipments per Year

Casks Required

Rail

Truck

Total

25-Year Cost (\$ million)

Capital

Shipping \& Maintenance

Tota1

Levelized Unit Cost $\left(\$ / \mathrm{m}^{3}\right)$
7\% Discount

10\% Discount
1

U

590

23

23

27.1

202

229.1

34

$$
2,360(+300)
$$

610

$$
1
$$

U

$1,520(+149)$

23

12

20

$55(+140)$

23

$32(+39)$

2
$2(+39)$

$63.3(+52)$

$159(-32)$

$222.3(-20)$

$\begin{array}{ll}41.7 & 159(-32) \\ 235 & 222.3(-20) \\ 276.7 & \end{array}$

$\begin{array}{llll}3,380 & 3,240(-4) & 4,090 & 3,280(-20) \\ 4,000 & 4,190(+5) & 5,049 & 4,780(-5)\end{array}$

\subsubsection{Effects on HLDW Transportation Due to Multiple Repository Location}

Two sets of multiple repository locations were considered for this analysis, 3 regional repositories and dual repositories. In the regional repository concept, SRP ships HLDW to a southern repository, west Valley ships to a northeastern repository, and Hanford and INEL ship to the northwest repository. With two repositories, SRP and West Valley ship to a northeastern repository and Hanford and the INEL ship to the northwestern repository. The HLDW transportation system requirements are presented in Table 5.12. For this comparison, rail shipments using cask concept 7 were assumed. The cost reduction of multiple repositories ranges from 20 to 26 percent, or about $\$ 50$ million. 
TABLE 5.12. HLDW Transportation Effects Due to Multiple Repository Locations (Cask Concept 7)

\begin{tabular}{|c|c|c|c|c|c|}
\hline & $\begin{array}{l}\text { Base Case } \\
\text { Single } \\
\text { Repository }\end{array}$ & $\begin{array}{c}\text { Regional } \\
\text { Repository }\end{array}$ & $\begin{array}{c}\text { Percent } \\
\text { Change } \\
\text { From } \\
\text { Base } \\
\end{array}$ & $\begin{array}{c}\text { Two } \\
\text { Repositories }\end{array}$ & $\begin{array}{c}\text { Percent } \\
\text { Change } \\
\text { From } \\
\text { Base } \\
\end{array}$ \\
\hline Casks Required & 23 & 19 & -17 & 21 & -9 \\
\hline \multicolumn{6}{|l|}{ 25-Year Cost (\$Million) } \\
\hline Capital & 27.1 & 23.0 & -15 & 25.2 & -7 \\
\hline Shipping \& Maintenance & 202 & 148 & -27 & 158 & -22 \\
\hline Total & 229.1 & 171.0 & -26 & 183.2 & -20 \\
\hline \multicolumn{6}{|l|}{ Levelized Unit Cost $\left(\$ / \mathrm{m}^{3}\right)$} \\
\hline $0 \%$ Discount & 3,380 & 2,470 & -27 & 2,650 & -21 \\
\hline $10 \%$ Discount & 4,000 & 2,740 & -31 & 2,960 & -26 \\
\hline
\end{tabular}

\subsubsection{Effects on HLDW Transportation Caused by Alternate Repository Locations}

The impact of selecting an alternate location for the western repository was evaluated for locations in the Southwest, the Mojave Desert, and for the Central Rockies. Rail shipments in cask concept 7 were used for this comparison. The effect on HLDW transportation with a single national repository is summarized in Table 5.13. The repository location's effect on transportation requirements with regional repositories is summarized in Table 5.14 . Since a large amount of HLDW originate in the Northwest, transportation costs increase as the repository location is moved from the Northwest. The increase ranges from $\$ 115$ million to $\$ 240$ million for the national repository and from $\$ 122$ million to $\$ 278$ million for the regional repositories. The increase is smaller in the national repository because the increase is partially offset by cost reduction in shipments from SRP. 
TABLE 5.13. HLDW Transportation Effects Due to Alternate Repository Locations - National Repository (Cask Concept 7)

\begin{tabular}{|c|c|c|c|c|c|c|c|}
\hline & $\begin{array}{l}\text { Base Case } \\
\text { Northwest } \\
\text { Repository }\end{array}$ & $\begin{array}{l}\text { Southwest } \\
\text { Repository }\end{array}$ & $\begin{array}{c}\text { Percent } \\
\text { Change } \\
\text { From } \\
\text { Base } \\
\end{array}$ & $\begin{array}{c}\text { Majave } \\
\text { Desert } \\
\text { Repository } \\
\end{array}$ & $\begin{array}{c}\text { Percent } \\
\text { Change } \\
\text { From } \\
\text { Base } \\
\end{array}$ & $\begin{array}{r}\text { Central } \\
\text { Rockies } \\
\text { Repository } \\
\end{array}$ & $\begin{array}{c}\text { Percent } \\
\text { Change } \\
\text { From } \\
\text { Base } \\
\end{array}$ \\
\hline Casks Required & 23 & 47 & +104 & 45 & +96 & 40 & +74 \\
\hline \multicolumn{8}{|l|}{$25-$ Year Cost ( $\$$ Mi11ion) } \\
\hline Capital & 27.1 & 57.3 & +111 & 55.2 & +104 & 48.4 & +79 \\
\hline Shipping \& Maintenance & 202 & 412 & +104 & 346 & +71 & 296 & +47 \\
\hline Total & 229.1 & 469.3 & +105 & 401.2 & +75 & 344.4 & +50 \\
\hline \multicolumn{8}{|l|}{ Levelized Unit Cost $\left(\$ / \mathrm{m}^{3}\right)$} \\
\hline $0 \%$ Discount & 3,380 & 6,920 & +105 & 5,920 & +75 & 5,090 & +50 \\
\hline $10 \%$ Discount & 4,000 & 8,300 & +108 & 7,350 & +84 & 6,340 & +59 \\
\hline
\end{tabular}

TABLE 5.14. HLDW Transportation Effects Due to Alternate Western Repository Locations Regional Repositories

\begin{tabular}{|c|c|c|c|c|c|c|c|}
\hline & $\begin{array}{l}\text { Base Case } \\
\text { Northwest } \\
\text { Repository }\end{array}$ & $\begin{array}{l}\text { Southwest } \\
\text { Repository }\end{array}$ & $\begin{array}{c}\text { Percent } \\
\text { Change } \\
\text { From } \\
\text { Base } \\
\end{array}$ & $\begin{array}{c}\text { Majave } \\
\text { Desert } \\
\text { Repository }\end{array}$ & $\begin{array}{c}\text { Percent } \\
\text { Change } \\
\text { From } \\
\text { Base } \\
\end{array}$ & $\begin{array}{c}\text { Central } \\
\text { Rockies } \\
\text { Repository }\end{array}$ & $\begin{array}{c}\text { Percent } \\
\text { Change } \\
\text { From } \\
\text { Base } \\
\end{array}$ \\
\hline Casks Required & 19 & 44 & +132 & 35 & +84 & 28 & +47 \\
\hline \multicolumn{8}{|l|}{ 25-Year Cost (\$Million) } \\
\hline Capital & 23.0 & 53.8 & +134 & 42.3 & +84 & 34.2 & +49 \\
\hline Shipping \& Maintenance & 148 & 396 & +168 & 293 & +98 & 259 & +75 \\
\hline Total & 171.0 & 449.8 & +163 & 335.3 & +96 & 293.2 & +71 \\
\hline \multicolumn{8}{|l|}{ Levelized Unit Cost $\left(\$ / \mathrm{m}^{3}\right)$} \\
\hline $0 \%$ Discount & 2,470 & 6,540 & +165 & 4,870 & +97 & 4,260 & +72 \\
\hline 10\% Discount & 2,740 & 7,840 & +186 & 5,890 & +115 & 5,100 & +86 \\
\hline
\end{tabular}





\section{$\underline{\text { REFERENCES }}$}

Adcock, F. C. and J. D. McCarthy. 1974. ATMX 600 Railcar Safety Analysis Report for Packaging. RFP-2244, Dow Chemical U.S.A., Rocky Flats Division, Golden, Colorado.

Eakes, R. G., et. al., TRU Waste Transportation Package Development, Proceedings of Patran 80, 6th International Symposium on the Packaging and Transportation of Radioactive Materials, Federal Republic of Germany, 1980.

Environmental and Other Evaluations of Alternatives for Long-Term Management of Stored INEL Transuranic Waste. 1979. D0E/ET-0081, U.S. Department of Energy, Assistant Secretary for Energy Technology, Offic of Nuclear Waste Management, Washington, DC.

Hanson, L. 1970. Engineering Evaluation of the Super Tiger ${ }^{8}$ Overpack Designed for the Shipment of Large Quantities of Hazardous Materials. Mechanics Research Inc., Tacoma, Washington.

NWTS Program Criteria for Geologic Disposal of Nuclear Waste-Waste Package Functional Criteria. 1980. ONWI-33(4), DRAFT, Office of Nuclear Waste Isolation operated by Battelle Memorial Institute, Columbus, Ohio.

Packaging of Radioactive Material for Transportation and Transportation of Radioactive Material Under Certain Conditions; Compatibility with IAEA Regulations, Federal Register, August 17, 1979, page 48234.

Requirements for Transportation of Radioactive Materials, Federal Register, January 8, 1979, page 1852 .

Shefelbine, H. C. 1978. Preliminary Evaluation of Characteristics of Defense Transuranic Waste. SAND 78-1850, Sandia Laboratories, Albuquerque, New Mexico.

Spent Fuel and Radioactive Waste Inventories and Projections as of December 31, 1980, DOE/NE-0017, U.S. Department of Energy, Office of Nuclear Waste Management and Fuel Cycle Programs, September 1981.

Spent Fuel and Waste Inventories and Projections, ORNL/TM-7320, Oak Ridge National Laboratories, Oak Ridge, Tennessee, June 30, 1980.

The National Atlas. 1970. U.S. Geological Survey.

U.S. Department of Energy. 1980. Final Environmental Impact Statement, Waste Isolation Pilot Plant. DOE/EIS 0026, U.S. Government Printing Office, Washington, D.C. 
U.S. Geological Survey for the Office of Policy and Program Development. Federal Railroad Administration, U.S. Department of Transportation. Transportation Maps of the U.S.

WIPP Conceptual Design Report. 1977. SAND 77-0274, Sandia Laboratories, Nuclear Waste Engineering Division, Albuquerque, New Mexico. 
$\underline{\operatorname{GLOSSARY}}^{(\mathrm{a})}$

$\underline{\text { SOURCE }}^{(b)}$

IAEA-WM

TWSOm

IAEA-W

IAEAm
DEFINITION

Canister

A rigid container for radioactive waste that is in direct contact with the waste or with disposable bags that may hold the waste. The canister may be lined with other materials such as plastic or cement. The canister provides physical containment but not shielding. A canister can have many shapes and can be made from a variety of materials.

Cargo Container

(See Transport Container)

Carrier

Any organization or private individual undertaking the conveyance of radioactive materials by any means of transport. The term includes both carriers for hire or reward (known as common or contract carriers), carriers on own account (known as private carriers), and freight forwarders.

Contact-Handled TRU Waste

Transuranic waste that does not require shielding other than that provided by its container. Solid or solidified materials that contain plutonium or other long-lived alpha emitters in known or suspected concentrations greater than $10 \mathrm{nCi} / \mathrm{g}$, but have sufficiently low external radiation levels after packaging (less than $200 \mathrm{mR} / \mathrm{hr}$ ) that the containers can be handled directly.

Containment

The retention of radioactive material in such a way that it is effectively prevented from becoming dispersed into the environment.

(a) Excerpted from K. J. Schneider et al, Transportation Considerations Related to Waste Forms and Canisters for Defense TRU Wastes, PNL 3841/TTC-0241, Pacific Northwest Laboratory, Richland, Washington, September 1981.

(b) See legend at end of glossary for definition of these symbols. 
SOURCE

IAEA

IAEAam

IAEAa

DEFINITION

Containment System

The components of the packaging specified by the designer as intended to retain the radioactive material during transport.

Transport Container

A container designed to facilitate the handling, transfer and carriage of goods by one or more modes of transport without intermediate removal and reloading of its contents. These containers are commonly designed to specified standards.

\section{Low-Level Solid (LLS) Radioactive Material}

Any of the following:

(a) Solids (e.g., consolidated wastes, activated materials) in which:

1) the activity under normal transport conditions is, and remains, distributed throughout a solid or a collection of solid objects, or is, and remains, uniformly distributed in a solid compact binding agent (such as concrete, bitumen, ceramic), and

2) the activity is, and remains, insoluble so that, even under loss of packaging, the loss of radioactive material per package resulting from the effects of wind, rain, etc., and from total immersion in water is limited to less than 0.1 the maximum activity of the material $\left(A_{2}\right)$ in a period of one week, and

3) the estimated activity averaged throughout the radioactive material does not exceed $2 \times 10^{-3}$ the maximum activity divided by the grams of material $\left(A_{2} / g\right)$.

(b) Objects of nonradioactive material contaminated with radioactive material, provided that the radioactive contamination is in a nonreadily dispersible form and the level of contamination averaged over $1 \mathrm{~m}^{2}$ (or the area of the surface if this is less than $1 \mathrm{~m}^{2}$ ) does not exceed

$20 \mu \mathrm{Ci} / \mathrm{cm}^{2}$ for beta and gamma emitters and low toxicity alpha emitters;

$2 \mu \mathrm{Ci} / \mathrm{cm}^{2}$ for other alpha emitters. 
Any of the following:

a) Uranium or thorium ores and physical or chemical concentrates of those ores.

b) Unirradiated natural or depleted uranium or unirradiated natural thorium.

c) Tritium oxide in aqueous solutions, provided the concentration does not exceed $10 \mathrm{Ci} /$ litre.

d) Materials in which the activity, under normal transport conditions, is, and remains, uniformly distributed and which the average estimated specific activity does not exceed $10^{-4}$ the maximum activity divided by the grams of material $\left(A_{2} / g\right)$.

e) Materials in which the activity is uniformly distributed and which, if reduced to the minimum volume under conditions likely to be encountered in transport, such as dissolution in water with subsequent recrystallization, precipitation, evaporation, combustion, abrasion, etc., would have an average estimated specific activity of no more than $10^{-4} \mathrm{~A}_{2} / \mathrm{g}$.

f) Objects of nonradioactive material contaminated with radioactive material, provided the nonfixed surface contamination does not exceed ten times the values given in IAEA Safety Series Report No. 6(1979), and the contaminated object or the contamination on the object, if reduced to the minimum volume under conditions likely to be encountered in transport, such as dissolution in water with subsequent recrystallization, precipitation, evaportation, combustion, abrasion, etc., would have an average estimated specific activity of no more than $10^{-4} \AA_{2} / g$.

g) Objects of nonradioactive material contaminated with radioactive material, provided that the radioactive contamination is in a nonreadily dispersible form and the level of contamination averaged over $1 \mathrm{~m}^{2}$ (or the area of the surface if this is less than $1 \mathrm{~m}^{2}$ ) does not exceed

$1 \mu \mathrm{Ci} / \mathrm{cm}^{2}$ for beta and gamma emitters and the low toxicity alpha emitters;

$0.1 \mu \mathrm{Ci} / \mathrm{cm}^{2}$ for other alpha emitters. 
SOURCE

49 CFR $171 \mathrm{~m}$

10 CFR 71.4, IAEA-W

10 CFR $71.4 \mathrm{~m}$

IAEA-Wm, IAEAm

IAEA-Wm
DEFINITION

Overpack

An enclosure that is used by a single consignor that can be used to consolidate two or more packages for convenience in handling (also Freight Container), or to provide protection of packages and/or containment of package contents in event of nonstandard conditions such as an accident.

Package

The packaging and its radioactive contents. It includes the waste form, including any container(s) and other engineered barriers (e.g., absorber materials), as it is prepared for handling, transport, storage and/or disposal. A container may be a permanent part of the waste or may be reusable (e.g., shielding cask, shock absorbers, etc.) for any waste management step.

Packaging

One or more receptacles and wrappers including absorbent material, spacing structures, thermal insulation, radiation shielding, devices for cooling and for absorbing mechanical shock, external fittings, neutron moderators, nonfissile neutron absorbers, and other supplementary equipment.

Radioactive Material

A material of which one or more constituents exhibit radioactivity. For purposes of regulation, this term is restricted to radioactive material with a radioactivity level or specific activity greater than a specified value. For transportation purposes, it is any material having a specific activity greater than $0.002 \mu \mathrm{Ci} / \mathrm{g}$.

Radioactive Waste

Any material containing or contaminated with radionuclides at concentrations or radioactivity levels greater than exempt quantities established by the regulatory authorities and for which there is no foreseen use. 
SOURCE

TWSOm

IAEA, 10 CFR $71 \mathrm{~m}$

10 CFR 71

\section{DEFINITION}

Remotely-Handled TRU Waste

Transuranic waste that requires shielding in addition to the provided by its container in order to protect people nearby. Solid or solidified materials (other than high-level wastes) that contain long-lived alpha emitters at concentrations greater than $10 \mathrm{nCi} / \mathrm{g}$, and have fission-product gamma-radiations levels (greater than $200 \mathrm{mR} / \mathrm{hr}$ ) that require biological shielding and remote-handling techniques even after packaging.

\section{Special Form Material}

An indispersible solid radioactive material or a sealed capsule containing radioactive material. The sealed capsule shall be so constructed that it can be opened only by destroying the capsule.

Special form material has any of the following physical forms of licensed material of any transport group:

a) The material is in solid form having no dimension less than 0.5 millimeter or at least one dimension greater than five millimeters; does not me1t, sublime, or ignite in air at a temperature of $1,000^{\circ} \mathrm{F}$.; will not shatter or crumble if subjected to the percussion test described in 10 CFR 71, Appendix D; and is not dissolved or converted into dispersible form to the extent of more than 0.005 percent by weight by immersion for 1 week in water at $68^{\circ} \mathrm{F}$ or in air at $86^{\circ} \mathrm{F}$.; or

b) The material is securely contained in a capsule having no dimension less than 0.5 millimeter or at least one dimension greater than five millimeters, which will retain its contents if subjected to the tests prescribed in 10 CFR 71, Appendix D; and which is constructed of materials which do not melt, sublime, or ignite in air at $1,475^{\circ} \mathrm{F}$, and do not dissolve or convert into dispersible form to the extent of more than 0.005 percent by weight by immersion for 1 week in water at $68^{\circ} \mathrm{F}$ or in air at $86^{\circ} \mathrm{F}$.

\section{Transport Group}

Any one of seven groups into which radionuclides in normal form are classified, according to their toxicity and their relative potential hazard in transport, in Appendix $C$ of 10 CFR 71. 
Transuranic nuclides are in Group I.

a) Any radionuclide not specifically listed in one of the groups in Appendix $\mathrm{C}$ shall be assigned to one of the Groups in accordance with the following table:

\begin{tabular}{|c|c|c|c|}
\hline \multirow[b]{2}{*}{ Radionuclide } & \multicolumn{3}{|c|}{ Radioactive half-life } \\
\hline & 0 to 1000 days & $\begin{array}{c}1000 \text { days to } \\
106 \text { years }\end{array}$ & Over $10^{6}$ years \\
\hline $\begin{array}{l}\text { Atomic } \\
\text { number 1- } \\
81\end{array}$ & Group III........ & Group II....... & Group III. \\
\hline $\begin{array}{l}\text { Atomic } \\
\text { number } 82 \\
\text { and over. }\end{array}$ & Group I....... & Group I....... & Group III. \\
\hline
\end{tabular}

IAEA-Wm

IAEA-Wm

\section{Transuranic Wastes}

Wastes containing quantities of transuranic radionuclides above agreed limits. The current value in the U.S.A. is $10 \mathrm{nCi} / \mathrm{g}$ of waste.

Transuranium Nuclides

Nuclides having an atomic number greater than that of uranium (i.e., greater than 92). The principal transuranium radionuclides of concern in radioactive waste management are tabulated below with their half-lives and decay modes.

\begin{tabular}{lrl}
\hline \multicolumn{1}{c}{ Nuclide } & $\begin{array}{c}\text { Half-Life } \\
\text { (Years) }\end{array}$ & Principal Decay Modes \\
\hline Neptunium-237 & $2,140,000$ & alpha \\
Plutonium-238 & 86 & alpha, spontaneous fission \\
Plutonium-239 & 24,390 & alpha, spontaneous fission \\
Plutonium-240 & 6,580 & alpha, spontaneous fission \\
Plutonium-242 & 379,000 & alpha \\
Americium-241 & 458 & alpha \\
Americium-243 & 7,950 & alpha \\
Curium-245 & 9,300 & alpha \\
Curium-246 & 5,500 & alpha, spontaneous fission
\end{tabular}

For waste management purposes in the U.S.A., Uranium-233 (alpha decay, half-life 160,000 years) and its decay daughter products are considered as transuranium nuclides. 
IAEAa

IAEAa

10 CFR $71 \mathrm{~m}$
Type A Packaging

Packaging that is designed to withstand the normal conditions of transport as demonstrated by the retention of the integrity of containment and shielding.

Type B Packaging

Packaging that is designed to withstand the damaging effects of a transport accident as demonstrated by the retention of the integrity of containment and shielding, to the extent required by the regulations, after the tests specified in the regulations.

Type A Quantity, and Type B Quantity and Large Quantity

A quantity of radioactive material the aggregate radioactivity of which does not exceed that specified in the following table:

\begin{tabular}{|c|c|c|c|}
\hline Transport Groups & $\begin{array}{l}\text { Type A Quantity } \\
\text { (in curies) }\end{array}$ & $\begin{array}{l}\text { Type B Quantity } \\
\text { (in curies) }\end{array}$ & $\begin{array}{l}\text { Large Quantity } \\
\text { (in curies) }\end{array}$ \\
\hline 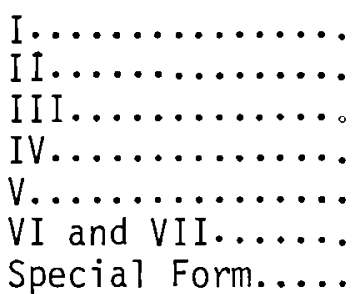 & $\begin{array}{r}0.001 \\
0.05 \\
3 \\
20 \\
20 \\
1,000(a) \\
20^{(a)}\end{array}$ & $\begin{array}{r}20 \\
20 \\
200 \\
200 \\
5,000 \\
50,000 \\
5,000\end{array}$ & $\begin{array}{l}\text { Quantity in } \\
\text { Excess } \\
\text { of } \\
\text { Type B }\end{array}$ \\
\hline
\end{tabular}

IAEA

Vehicle

A road vehicle (including an articulated vehicle, i.e. a tractor and semi-trailer combination) or railroad car or railway wagon. A trailer shall be considered as a separate vehicle.

Legend

Dictionary - from Webster's Dictionary

IAEA - from IAEA Safety Series No. 6, 1979

IAEA-W - from IAEA Waste Management Glossary

10 CFR 71 - from 10 CFR 71

49 CFR 171 - from 49 CFR 171

TWSO - from Report DOE/AL/TRU 8002

a - abbreviated from that in the source

$m$ - modified from that in the source 


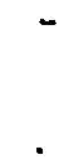


APPENDIX A

\section{TLM OPERATING INSTRUCTIONS}

The TLM is written in ASCII FORTRAN and is operational on the UNIVAC 1110 computer at DOE-RL. A11 of the required information is input on punched cards. Most of the required data is input in namelist CARD. The only data not in namelist CARD is a single case title card and the names of the waste origin facilities and the waste processing facilities.

A typical control deck to process the TLM is shown in Table A.1. The following variables are input via namelist CARD.

NYR - Number of years, maximum $=25$.

NCAT - Number of waste categories, maximum $=10$.

NSITE - Number of waste origin sites, maximum $=12$.

NCONV - Number of waste treatment facilities, maximum $=2$, may be zero.

KILPR - Delete printout switch. KILPR - 1, delete source and processing status reports. KILPR - 2, delete source and processing and disposal site status reports.

VPST $(10,12,3)$ - Volume per truck shipment.

The first subscript is waste category.

The second subscript is waste origin.

The third subscript is shipment destination, 1 and 2 are for waste treatment facilities, 3 is for waste disposal facility.

VPSR $(10,12,3)$ - Volume per rail shipment. Subscripts are the same as VPST.

CONVF $(10,12,3)$ - Volume reduction fraction. Subscripts are the same as VPST. This array is initialized to 1.0 . 
CAPAC $(25,3)$ - Waste process facility volume input capacity.

The first subscript is year.

The second subscript is process index. 1 or 2 are for waste treatment facilities, 3 is for waste disposal facility.

WTT $(10,12,3)$ - Relative weighting factors for truck shipments, used for allotting shipments from the waste origin sites. The subscripts are the same as VPST.

WTR $(10,12,3)$ - Relative weighting factors for rail shipments, used for allotting shipments from the waste origin sites. The subscripts are the same as VPST.

TWTT (2) - Relative weighting factors for truck shipments of treated waste, used for allotting shipments from the treatment facility to the disposal site. It is assumed that only a single waste category is output from each treatment facility. The subscript is the treatment facility.

TWTR (2) - Relative weighting factors for rail shipments of treated waste. The subscript is the treatment facility.

TVPST (2) - Volume per truck shipment for treated waste. The subscript is the treatment facility.

TVPSR (2) - Volume per rail shipment for treated waste. The subscript is the treatment facility.

WINV $(26,10,12)$ - Waste backlog at the beginning of the year at the waste origin sites. This array is used as internal working array, only the first year should be input.

The first subscript is year.

The second subscript is waste category.

The third subscript is waste origin site.

WGEN $(25,10,12)$ - Waste generation rate at the waste origin sites. The subscripts are the same as for WINV, but only for 25 years. 
TINV $(26,2)$ - Inventory of treated waste at the beginning of the year This array is used as an internal working array; only the first year should be input.

The first subscript is year.

The second subscript is treatment facility.

TABLE A.1. TLM Control Cards

$\nabla$ RUN(s) ENGEL/65/0/0/0, BCW 520/BCW 520, WIPP. (s) ENGEL

$\nabla \operatorname{IDENT}(s) .(s)$ RL(s) ENGEL/BNW

$\nabla$ PASSWORD(s)WIPP

$\nabla$ ASG,A(s)WIPP (TCM program file attachment)

$\nabla$ ASG,C(s) FILENAME. (Output file attachment)

$\nabla$ USE (s) 25., FILENAME.

$\nabla A S G, T(s) D A T$ (Input file attachment)

$\nabla$ DATA, IL DAT (Build and list input data element DAT) CASE TITLE (a descriptive titie)

(s) \$CARD (namelist ident card)

Data Cards in Namelist Format

(s) \$END (end of name list data)

WASTE CATEGORY NAME (one card for each waste category)

ORIGIN NAME CARDS (one card for each waste origin)

TREATMENT FACILITY NAME (one card for each waste treatment

facility - if no treatment facilities, one blank card must

be included)

DISPOSAL SITE NAME CARD

$\nabla$ END (end of DATA detail cards)

$\nabla \times Q T$ (s)WIPP.ABS

$\nabla$ ADD(s)DAT. (insert data element DAT in runstream)

$\nabla$ FIN (end of runstream)

The $(s)$ designates a single blank space. No other blank spaces. 
. 
APPENDIX B

\section{TCM OPERATING INSTRUCTIONS}

The TCM is written in ASCII FORTRAN and is operational on the UNIVAC 1110 computer at DOE-RL.

The input requirements for the TCM are divided into four components. The first component is the waste transportation logistics file. This file is created by the TLM program and is stored on disc. Access is achieved via the UNIVAC control (see Table B.1).

The second component contains the variables which do not change routinely. These include the shipping rates, transit times, and final destination. The values of these variables are initialized internally in FORTRAN DATA statements. These initial values may be changed through NAMELIST.

The third component contains those variables which provide the case control and case specific parameters. These include carrier configuration, operating lives, and cost factors.

The fourth component contains the controls for the investment analysis (if required). 
TABLE B.1. Sample Input Deck

$\nabla$ RUN COLE/65/0/0/0, BCW520/BCW520, WIPP.BMCOLE

$\nabla$ IDENT . BM COLE/BNW (User identification)

$\checkmark$ PASSWD WIPP (Password)

$\nabla$ ASG, A WIPP2 (Transportation logistics file attachment)

$\nabla$ USE 25, WIPP2 (Transportation logistics file input unit assignment)

$\nabla X Q T$ WIPPT . TRNABS

\$ ENDAT (NAMELIST INPUT)

$\$ E N D$

CARD 1 (Case controls and parameters)

CARD 2 (Case controls and parameters)

CARD 3 (Case controls and parameters)

CARD 4 (Case controls and parameters)

CARD 5 (Case controls and parmeters;

CARD 6 (Investment analysis controls)

CARD 7 (Investment analysis controls)

$\nabla$ FIN 
\$INDAT

WHERE:

$$
\begin{aligned}
\text { I = ORIGIN - } 1 & =\text { IDAHO FALLS } \\
2 & =\text { HANFORD } \\
3 & =\text { SAVANNAH RIVER } \\
4 & =\text { LOS ALAMOS } \\
5 & =\text { OAK RIDGE } \\
6 & =\text { NEVADA TEST SITE } \\
7 & =\text { ROCKY FLATS } \\
8 & =\text { MOUND LAB } \\
9 & =\text { ARGONNE } \\
10 & =\text { BETTIS } \\
11 & =\text { NOT USED } \\
12 & =\text { NOT USED } \\
13 & =\text { TREATED WASTE (FACILITY 1) } \\
14 & =\text { TREATED WASTE (FACILITY 2) }
\end{aligned}
$$

WHERE:

$$
\begin{aligned}
\mathrm{J}=\text { DESTINATION }-1 & =\text { TREATMENT FACILITY } 1 \\
2 & =\text { TREATMENT FACILITY } 2 \\
3 & =\text { REPOSITORY }
\end{aligned}
$$

SRR $(I, J)=$ SHIPPING RATE, \$/TRIP, RAIL-TRUPACT

SRGR $(I, J)=$ SHIPPING RATE, \$/TRIP, RAIL-ATMX

SRHH $(I, J)=$ SHIPPING RATE, \$/TRIP, TRUCK-SUPER TIGEK ${ }^{\circledast}$ or TRUPACT

SRGT $(I, J)=$ SHIPPING RATE, \$/TRIP, TRUCK-TRUPACT AND TRAILER

$\operatorname{TTR}(I, J)=$ TURN AROUND TIME, DAYS - RAIL

TTT $(I, J)=$ TURN AROUND TIME, DAYS - TRUCK

LDES = FINAL DESTINATION $-1=$ TREATMENT FACILITY 1

$$
2=\text { TREATMENT FACILITY } 2
$$$$
3=\text { REPOSITORY }
$$

\$END 


\section{CARD INPUT - CASE CONTROLS AND PARAMETERS}

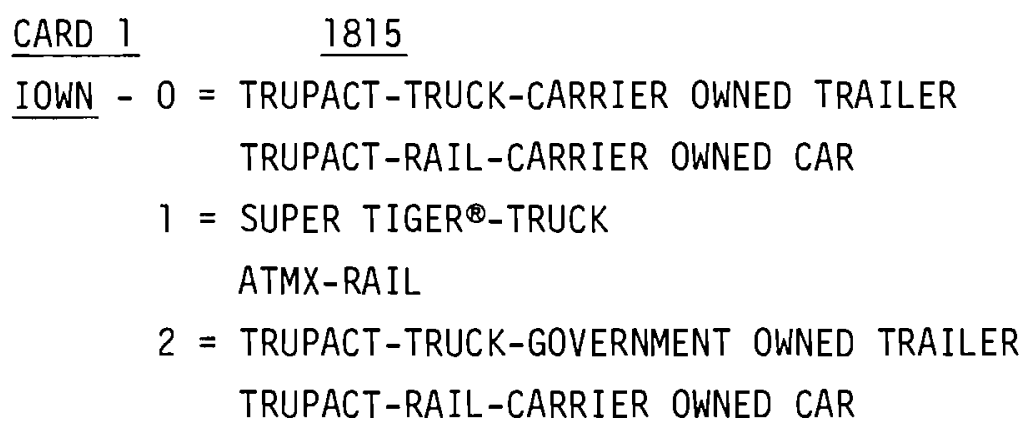

$\underline{\text { ICO }}-0=$ CASK IS GOVERNMENT OWNED

1 = CASK IS CARRIER OWNED

CYR - NUMBER OF HAULING DAYS PER YEAR

LEG - $0=$ NO FINANCIAL REPORTS

. 1 = FINANCIAL REPORTS FOR EACH ORIGIN/DESTINATION LEG

2 = FINANCIAL REPORTS FOR EACH ORIGIN/DESTINATION LEG PLUS AGGREGATE

IBY - BEGINNING YEAR OF ANALYSIS

LEAD - LEAD TIME FOR CAPITAL INVESTMENT, YEARS BEFORE FIRST YEAR OF OPERATION

IU - LOGICAL UNIT FOR READING THE TRANSPORTATION LOGISTICS (NORMALLY-25; see Table B.1)

NCPT - NUMBER OF CASKS PER TRUCK TRAILER (where applicable)

NTPT - NUMBER OF TRAILERS PER TRUCK TRACTOR (where applicable)

NCPC - NUMBER OF CASKS PER CAR (RAIL)

NCPE - NUMBER OF CARS PER ENGINE (RAIL)

TRLLIF - TRAILER LIFE, YEARS (USED ONLY IF IOWN $=1,2$ )

CARLIF - CAR LIFE, YEARS (USED ONLY IF IOWN $=1$ )

CASKLIF - CASK LIFE, YEARS (USED ONLY IF ICO $=0$ )

IDUM - NOT USED

NNYR - NUMBER YEARS OF ANALYSIS 
$\underline{\text { CARD } 2} \underline{2 I 5}$

PTCPT - NUMBER OF PTRU CASKS PER TRUCK TRAILER

PTCPC - NUMBER OF PTRU CASKS PER RAIL CAR

$\underline{\text { CARD } 3} \quad \underline{8 F 10.0} \quad$ \$ $=$ MONETARY UNITS DESCRIBED ON CARD 4)

CSKCST - TRUCK CASK COST, \$/CASK (USED ONLY IF ICO = 0)

CASKCSR - RAIL CASK COST, \$/CASK (USED ONLY IF ICO = 0)

TRLCST - TRAILER COST, \$/TRAILER (USED ONLY I'F IOWN = 2)

PTTCC - PTRU TRUCK CASK COST, \$/CASK

CSKMN - TRUCK CASK MAINTENANCE COST, \$/CASK/YEAR (USED ONLY IF ICO = 0 )

CSKMNR - RAIL CASK MAINTENANCE COST, \$/CASK/YEAR (USED ONLY IF ICO = 0)

TRLMN - TRUCK TRAILER MAINTENANCE COST, \$/TRAILER (USED ONLY IF IOWN = 2)

PTRCC - PTRU RAIL CASK COST, \$/CASK

$\underline{\text { CARD } 4} \quad \underline{8 F 10.0} \quad \underline{(\$=\text { MONETARY UNITS DESCRIBED ON CARD 4) }}$

CASKHND - CASK HANDLING COST, \$/SHIPMENT

ASCT - ADDITIONAL TRUCK SHIPPING COSTS FOR CARRIER OWNED CASK, \$/DAY (USED ONLY IF ICO = 1)

ASCR - ADDITIONAL RAIL SHIPPING COSTS FOR CARRIER OWNED CASK, \$/DAY (USED ONLY IF ICO $=1$ )

ESK - COST ESCALATION FACTOR OR INPUT TO OUTPUT UNIT CHANGE, FRACTION

REDHH - COST REDUCTION FACTOR FOR MORE THAN ONE TRUCK SHIPMENT PER DAY FOR TRUPACT OR SUPER TIGER ${ }^{\circledR}$

REDGR - COST REDUCTION FACTOR FOR TRAIN LOAD (20 + CARS) FOR ATMX

REDRR - COST REDUCTION FACTOR FOR TRAIN LOAD $(20$ + CARS) FOR TRUPACT

CARD $5 \quad \underline{3 F 10.0}$

PTCMNT - PTRU - TRUCK CASK MAINTENANCE COST, \$/CASK/YEAR

PTCMNR - PTRU - RAIL CASK MAINTENANCE COST, \$/CASK/YEAR

PTCHN - PTRU - PTRU CASK HANDLING COST \$/SHIPMENT

CARD $6 \quad 20 A 4$

TITLE 1 - MONETARY UNITS FOR OUTPUT 


\section{CARD INPUT - INVESTMENT ANALYSIS CONTROLS}

CARD $7 \quad 5 A 4, F 10.0,15,5 F 5.0$

KUNIT - ALPHA DESCRIPTION FOR UNIT PRICE OUTPUT

UNIT - CONVERSION FACTOR FOR UNIT COSTS (INTERNAL UNITS TO OUTPUT UNITS)

INT - NUMBER OF DISCOUNT RATES (5 MAX)

$\underline{X I N T L C(I)}$ - DISCOUNT RATE, PERCENT ( $I=1$, INT) 


\section{DISTRIBUTION}

No. of

Copies

\section{OFFSITE}

G. C. Allen, Jr. Sandia National Laboratories Division 9783

Albuquerque, NM 87185

T. D. Anderson

Department of Energy

Routing NE-340

Washington, D.C. 20545

W. W. Ballard

Department of Energy

Routing NE-340

Washington, D.C. 20545

R. G. Baxter

Savannah River Plant

Aiken, SC 29801

C. Belote

Nuclear Regulatory Research

Office of Transportation

Materials Risk Branch

5650 Nicholson Lane

Washington, D.C. 20555

L. Benner

National Transportation

Safety Board

Department of Transportation

Washington, D.C. 20594

W. S. Bennett

Rockwell International

TWSO

P.0. Box 464

Golden, C0 80401

R. M. Bernero

Office of Nuclear Regulatory Research

U.S. Nuclear Regulatory Commission

Washington, D.C. 20555
No. of

Copies

R. M. Burgoyne

Transportation and Storage

General Atomic Company

P.0. Box 81608

San Diego, CA 92138

K. A. Carlson

DOE Albuquerque Operations Office

Albuquerque, NM 87115

J. W. Cashwe11

Sandia National Laboratories

Division 9783

Albuquerque, NM 87185

A. A. Churm

Chicago Patent Group

DOE Chicago Operations Office

9800 South Cass Avenue

Argonne, IL 50439

F. E. Coffman

Department of Energy

Routing NE-340

Washington, D.C. 20545

N. Darmstader

American Trucking Associaton

1616 P Street, NW

Washington, D.C. 20036

27 DOE Technical Information Center

D. A. Edling

Mound Laboratory

P.0. Box 32

Miamisburg, OH 54342

F. P. Falci

Department of Energy

Routing NE-340

Washington, D.C. 20545 
No. of

Copies

R. F. Garrison

Department of Energy

Routing NE-340

Washington, D.C. 20545

M. Gordon

Atomic Industrial Forum

7101 Wisconsin Avenue

Washington, D.C. 20014

0. P. Gormiey

Department of Energy

Routing NE-340

Washington, D.C. 20545

R. J. Hall

Office of NWTS Integration

Battelle Project Management

Division

505 King Ave.

Columbus, $\mathrm{OH} 43201$

R. Horn

Office of Systems Research and Analysis

Transportation Systems Center

Department of Transportation

Cambridge, MA 02142

R. M. Jefferson

Sandia National Laboratories

Dept. 9780

Attn: TTC Master File (1)

A1buquerque, NM 87185

R. H. Jones

P.0. Box 24036

San Jose, CA 95125

D. Joy

Oak Ridge National Laboratory

P.0. Box $X$

Oak Ridge, TN 37830
No. of

Copies

P. Kranach, Librarian

Westinghouse Electric

Advanced Energy Systems Division

P.0. Box 10864

Pittsburg, PA 15236

R. Laufer

NUCLEONICS WEEK

1221 Avenue of the Americas

New York, NY 10020

M. J. Lawrence

Department of Energy

Routing NE-340

Washington, D.C. 20545

R. Y. Lowrey

DOE Alburquerque Operations Office

A1buquerque, NM 87115

R. E. Luna

Sandia Nationa 1 Laboratories

Diversion 9781

Albuquerque, NM 87185

J. C. Malaro

Nuclear Regulatory Commission

Mai1 Stop NL5650

Washington, D.C. 20555

C. H. Mayer

Tri-State Motor Transit Co., Inc.

P.0. Box 113

Joplin, M0 64801

J. D. MCClure

Sandia National Laboratories

Division 9781

Albuquerque, NM 87185

W. R. McDone11

Research Associate

Operational Planning Division

Savannah River Laboratory

Aiken, SC 29801 
No. of

Copies

D. McGoff

U.S. Department of Energy

Routing NE-340

Washington, D.C. 20545

R. G. Merlini

Rockwe 11 International TWSO

P. 0. Box 464

Golden, CO 80401

R. M. Moser

DOE Chicago Operations Office

9800 South Cass Avenue

Argonne, IL 60439

R. Moyer

Savannah River Plant

Aikens, SC 29801

G. Oerte I

Department of Energy

Routing NE-340

Washington, D.C. 20545

R. W. Peterson

Office of NWTS Integration

Battelle

Project Management Diversion

505 King Avenue

Columbus, $\mathrm{OH} 43201$

R. B. Pope

Sandia National Laboratories

Division 9782

Aibuquerque, NM 87185

R. R. Rawl

Office of Hazardous Materials Regulations

U.S. Department of Transportation

4007 th Street, SW

Washington, D.C. 20590

J. L. Ridihalgh

Ridihalgh, Eggers \& Associates

2112 Iuka Avenue

Corumbus, $\mathrm{OH} 43201$
No. of

Copies

L. E. Romesberg

Sandia Nationa 1 Laboratories

Division 9782

Aibuquerque, NM 87185

L. D. Santman

Materials Transportation Bureau

Department of Transportation

2100 Second Street, SW

Washington, D.C. 20590

L. B. Shappert

Oak Ridge National Laboratory

P.0. Box $X$

Oak Ridge, TN 37830

E. W. Shepard

Sandia National Laboratories

Division 9781

Albuquerque, NM 87185

C. G. Shirley

Sandia National Laboratories

Division 4553

Albuquerque, NM 87185

J. A. Sisier

Department of Energy

Routing NE-340

Washington, D.C. 20545

S. H. Sutherland

Sandia National Laboratories

Division 9783

Albuquerque, NM 87185

W. R. Teer

Transnuclear Inc.

One N. Broadway

White Plains, NY 10601

Transportation Department

Southern States Energy Board

One Exchange Place, Suite 1230

Atlanta, GA 30341 
No. of

Copies

4 TTC Library

Sandia National Laboratories

Dept. 4551

Albuquerque, NM 87185

M. B. Vigil

Sandia National Laboratories

Division 4553

Albuquerque, NM 87185

M. Warrant

INEL/EG\&G

P. 0. Box 1625

Idaho Falls, ID 83401

R. F. Williams

Electric Power Research Institute

P. 0. Box 10412

Palo Alto, CA 94304

E. L. Wilmot

Sandia National Laboratories

Division 9781

Albuquerque, NM 87185

Nuclear Safety Research Association P.0. Box 1307

Falls Church, VA 22041
No. of

Copies

ONSITE

6 DOE-Richland Operations Office

E. A. Bracken

S. K. Moy

J. M. Peterson

H. E. Ransom

J. J. Schreiber

M. W. Shupe

43 Pacific Northwest Laboratory

W. B. Andrews (10)

N. M. Burleigh

T. D. Chikalla

B. M. Cole (3)

P. M. Daling

R. L. Engel

A. L. Franklin

M. R. Kreiter

R. E. Rhoads

K. J. Schneider

C. L. Timmerman

L. D. Williams

M. K. White

Technical Information Ma

Publishing Coordination

Transportation Library, Sigma 4 (5)

Battelle-Human Affairs Research Center
A. H. Schilling
C. R. Schuller

Rockwell Hanford Operations

R. E. Cross

$\underline{\text { UNC }}$

J. M. Heaberlin 